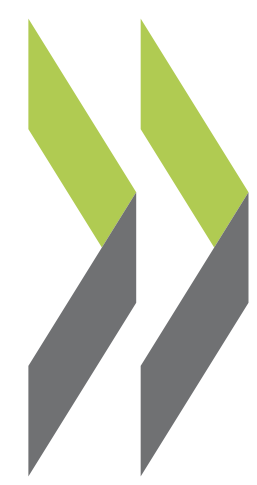

OECD Economics Department Working Papers No. 1241

Raising competitiveness and long-term growth of the Slovenian economy

\section{Urban Sila,}

Nataša Jemec, Hermes Morgavi 
Organisation de Coopération et de Développement Économiques

Organisation for Economic Co-operation and Development

25-Jun-2015

ECONOMICS DEPARTMENT

English - Or. English

\section{RAISING COMPETITIVENESS AND LONG-TERM GROWTH OF THE SLOVENIAN ECONOMY}

ECONOMICS DEPARTMENT WORKING PAPERS No. 1241

By Urban Sila, Nataša Jemec and Hermes Morgavi

OECD Working Papers should not be reported as representing the official views of the OECD or of its member countries. The opinions expressed and arguments employed are those of the author(s).

Authorised for publication by Alvaro Pereira, Director, Country Studies Branch, Economics Department.

All Economics Department Working Papers are available at www.oecd.org/eco/workingpapers

JT03379428

Complete document available on OLIS in its original format

This document and any map included herein are without prejudice to the status of or sovereignty over any territory, to the delimitation of international frontiers and boundaries and to the name of any territory, city or area. 
OECD Working Papers should not be reported as representing the official views of the OECD or of its member countries. The opinions expressed and arguments employed are those of the author(s).

Working Papers describe preliminary results or research in progress by the author(s) and are published to stimulate discussion on a broad range of issues on which the OECD works.

Comments on Working Papers are welcomed, and may be sent to the Economics Department, OECD, 2 rue André-Pascal, 75775 Paris Cedex 16, France, or by e-mail to eco.contact@oecd.org.

The statistical data for Israel are supplied by and under the responsibility of the relevant Israeli authorities. The use of such data by the OECD is without prejudice to the status of the Golan Heights, East Jerusalem and Israeli settlements in the West Bank under the terms of international law.

\section{(C) OECD (2015)}

You can copy, download or print OECD content for your own use, and you can include excerpts from OECD publications, databases and multimedia products in your own documents, presentations, blogs, websites and teaching materials, provided that suitable acknowledgment of OECD as source and copyright owner is given. All requests for commercial use and translation rights should be submitted to rights@oecd.org 
ECO/WKP(2015)59

\section{ABSTRACT/RÉSUMÉ}

\section{Raising competitiveness and long-term growth of the Slovenian economy}

The rapid growth after independence stopped in 2008 as the global crisis exposed important structural weaknesses. Large state involvement and rigid labour and product markets lowered productivity. Weak corporate governance and easy credit before the crisis led to high indebtedness and overinvestment. Slovenia was slow to deal with the underlying structural problems. Gradually, important reforms have been implemented which raised credibility of Slovenia in the financial markets and boosted confidence. But economic recovery has been sluggish, many people are unemployed and living standards still remain below the pre-crisis levels. Cost competitiveness and export market performance deteriorated, and there have been marked improvements only recently. Better corporate governance and management practices in the state owned sector and privatisations can attract FDI and raise efficiency. Low innovative activity could be boosted by more FDI, stronger framework for entrepreneurial activity and better start-up support. Relatively high minimum wage is potentially reducing employment opportunities of low-skilled workers. Limiting the minimum wage growth, and lowering the high tax wedge on labour income could boost employment. Efficiency should be raised in early and tertiary education to enhance skills. Despite generous public support, overall students' performance could be improved and there are marked differences between students from different socioeconomic backgrounds.

This Working Paper relates to the 2015 OECD Economic Survey of Slovenia (www.oecd.org/eco/surveys/economicsurvey-slovenia.htm).

JEL classification: E24, J24, O3, L33, G3, L26, K2, F21, I2, H2

Keywords: Slovenia, productivity, labour market, R\&D spending, innovation, public ownership, business environment, education, taxation

\section{Renforcer la de la compétitivité et la croissance à long terme de l'économie Slovène}

La croissance rapide suite à l'indépendance s'est arrêtée en 2008 alors que la crise mondiale a révélé d'importantes faiblesses structurelles. La participation de l'État et des marchés du travail rigides ont abaissé la productivité. Une faible gouvernance des entreprises et une facilité d'accès au crédit avant la crise ont conduit à un endettement élevé et au surinvestissement. La Slovénie a été lente à traiter les problèmes structurels sous-jacents. Peu à peu, des réformes importantes ont été mises en œuvre qui ont amélioré la crédibilité de la Slovénie dans les marchés financiers et ont renforcé la confiance. Mais la reprise économique a été lente, beaucoup de gens sont au chômage et les conditions de vie restent toujours en dessous des niveaux d'avant-crise. La compétitivité des coûts et la performance des marchés d'exportation se sont détériorées, il y a eu des améliorations marquées que récemment. Des meilleures pratiques de gouvernance d'entreprise et de gestion des secteurs conduits par l'État et les privatisations peuvent attirer l'IDE et augmenter l'efficacité. Une faible activité innovante pourrait être stimulée d'avantage par l'IDE, en créant un environnement plus solide pour l'activité entrepreneuriale et un meilleur support pour de nouvelles entreprises de petite taille. Le salaire minimum relativement élevé réduit potentiellement les possibilités d'emploi de travailleurs peu qualifiés. Limiter la croissance du salaire minimum, et l'abaissement de la charge fiscale sur les revenus du travail pourrait stimuler l'emploi. L'efficacité doit être soulevée dans l'éducation précoce et tertiaire pour améliorer les compétences. Malgré le soutien public, la performance de l'ensemble des étudiants pourrait être améliorée et il y a des différences marquées entre les élèves de différents milieux socio-économiques.

Ce Document de travail se rapporte à l'Étude économique de l'OCDE de la Slovénie, 2015 (www.oecd.org/fr/eco/etudes/etude-economique-slovenie.htm).

Classification JEL: E24, J24, O3, L33, G3, L26, K2, F21, I2, H2

Mots clefs : Slovénie, la productivité, le marché du travail, les dépenses de R \& D, l'innovation, la propriété publique, l'environnement des affaires, l'éducation, la fiscalité 


\section{TABLE OF CONTENTS}

\section{RAISING COMPETITIVENESS AND LONG-TERM GROWTH OF THE SLOVENIAN ECONOMY ...7}

Living standards have fallen since the crisis primarily due to lower labour utilisation ...........................7

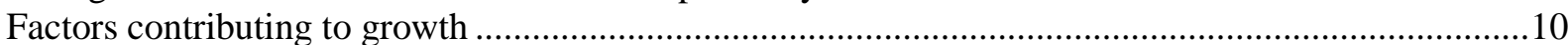

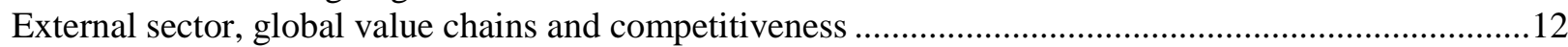

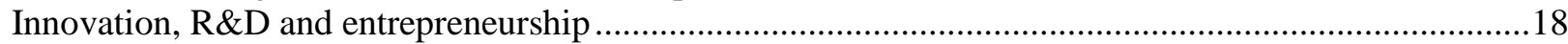

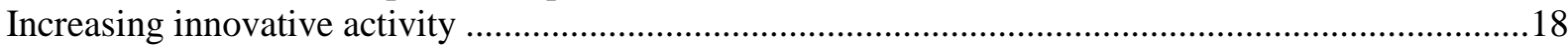

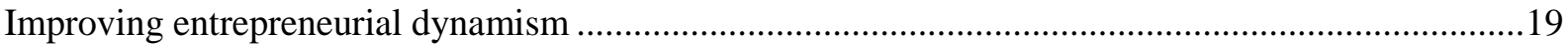

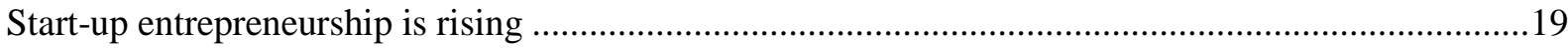

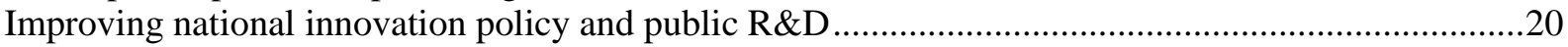

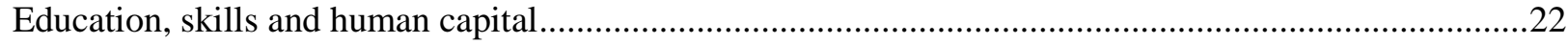

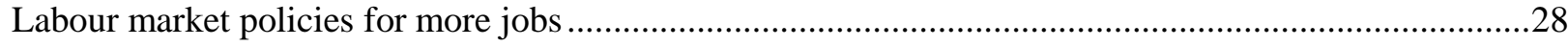

Lowering barriers to product market competition and improving the business environment ...................34

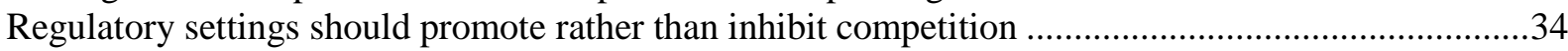

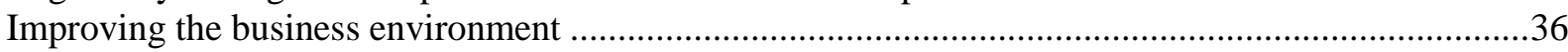

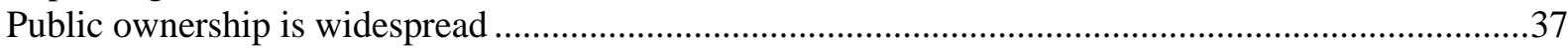

Rationalising public ownership, privatisations and corporate governance .........................................38

Less public ownership and deeper capital markets would attract more FDI ........................................39

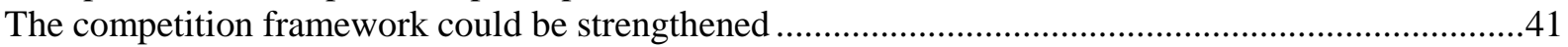

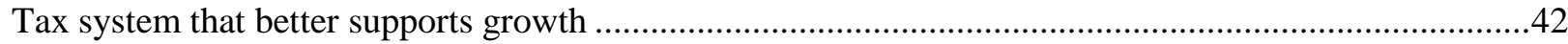

Relatively high tax burden is primarily levied on consumption and labour.........................................42

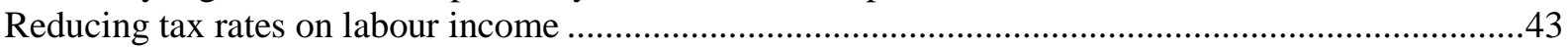

Increasing the reduced VAT rates and making tax expenditures fairer ................................................44

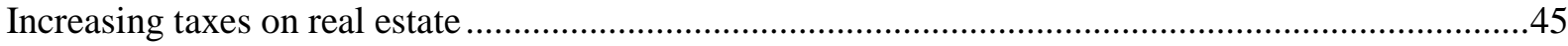

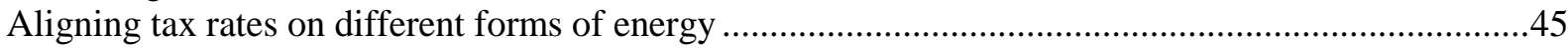

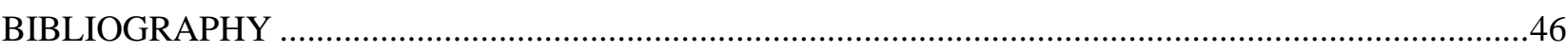

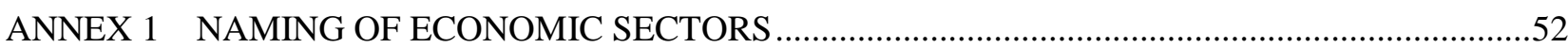

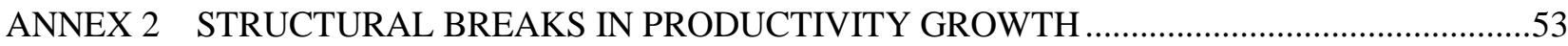

ANNEX 3 THE IMPACT OF BUSINESS ENVIRONMENT ON PRODUCTIVITY AND ON FDI ....55

\section{Tables}

1. 1997/2007 Growth accounting in $\mathrm{CEECs}^{1}$, Euro Periphery ${ }^{2}$ and EU3 ${ }^{3}$...................................11

2. Productivity growth has been fastest in high-technology manufacturing..................................17

3. Inactivity traps and unemployment traps are high in international comparison..........................30

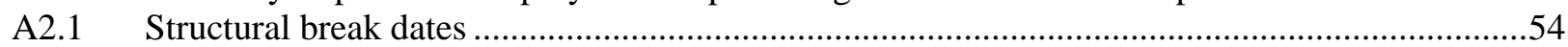

A3.1 Determinants of productivity - panel of OECD member countries ........................................55

A3.2 Influence of policy indicators on FDI intensity and R\&D intensity .........................................56

A3.3 The impact on Influence of R\&D intensity, capital intensity and FDI intensity

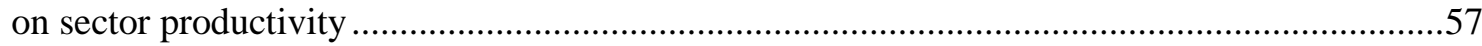




\section{Figures}

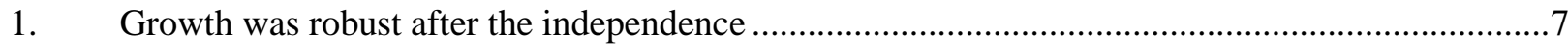

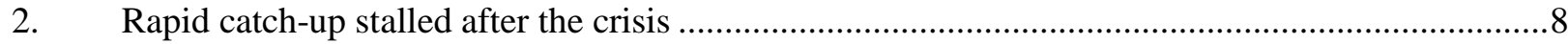

3. There has been large adjustment in labour utilisation after the crisis ...........................................

4. Growth in value added per worker turned negative in most sectors, while

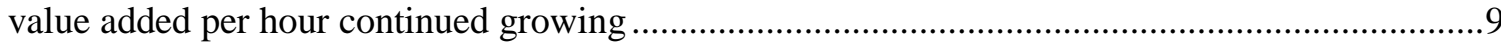

5. There is scope to improve productivity in several sectors ......................................................

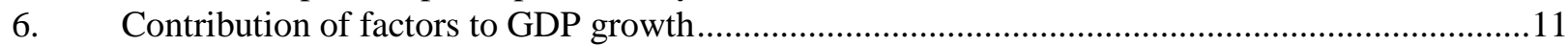

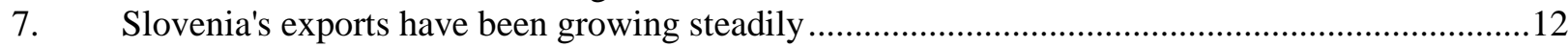

8. In the post-crisis period Slovenian exports have under-performed............................................13

9. Slovenia's improvements in cost competitiveness lag some peers ............................................13

10. Slovenia's export market performance has stagnated since the crisis .........................................14

11. The share of domestic value added in gross exports is still low ...............................................14

12. Slovenia has a high GVC participation index due to high backward participation ......................15

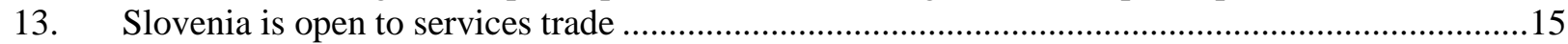

14. High-technology goods have increased their weight in export ................................................16

15. Share of high and medium technology manufacturing is relatively high.....................................16

16. Labour productivity and wages are higher in high technology manufacturing ............................17

17. Slovenia does well in terms of inputs into innovation process, but innovative activity is low .......18

18. Most relevant instruments of public funding of business R\&D, 2014 ...................................21

19. Slovenia has one of the highest variations in mathematics performance between schools ...........23

20 Difference in disciplinary climate between advantaged and disadvantaged schools is

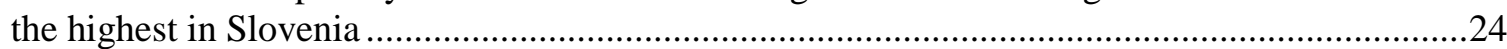

21. Probability of students whose parents have low levels of education attending

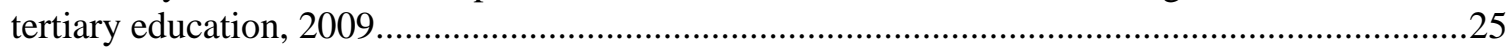

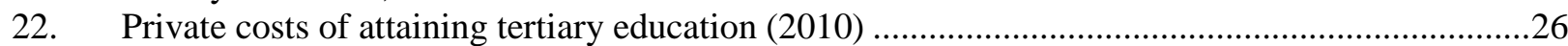

23. Mismatches on the labour market have increased for highly educated people ..............................26

24. Annual expenditure per student by educational institutions for all services by level of education, 2011

25. Long-term unemployment is high and youth unemployment has risen .....................................29

26. Slovenia is one of the countries with the highest minimum wage relative to the median wage ....31

27. How did the firms react to change in minimum wage legislation................................................. 31

28. The employment protection legislation index in Slovenia prior to and following

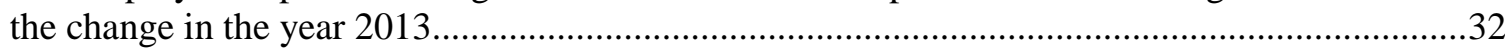

29. The effects of the 2013 labour market reform on firms' employment decisions

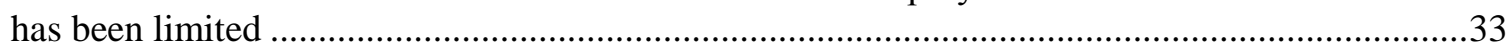

30. Slovenia spends less on active labour market programmes than majority of other countries.........34

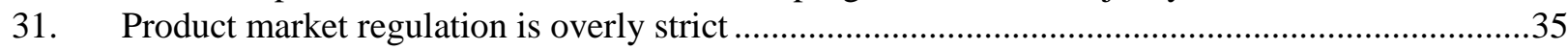

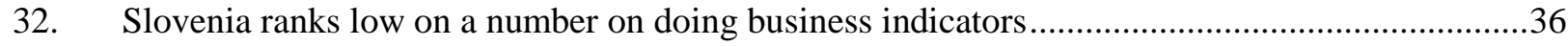

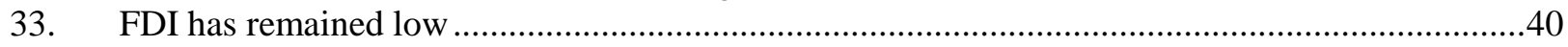

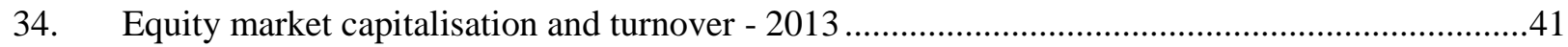

35. Relatively high tax burden is primarily levied on consumption and labour ...............................42

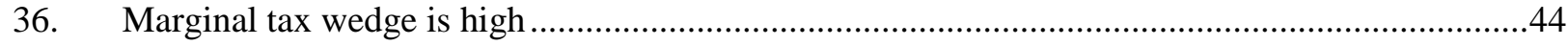

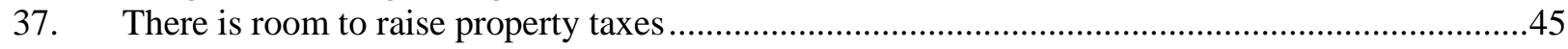

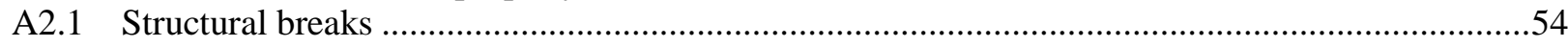

\section{Boxes}

Box 1. High-technology manufacturing in Slovenia 
ECO/WKP(2015)59 
ECO/WKP(2015)59

\title{
RAISING COMPETITIVENESS AND LONG-TERM GROWTH OF THE SLOVENIAN ECONOMY
}

\author{
By Urban Sila, Nataša Jemec and Hermes Morgavi ${ }^{1}$
}

\section{Living standards have fallen since the crisis primarily due to lower labour utilisation}

1. After independence upon the break-up of Yugoslavia in 1991, Slovenia experienced robust growth (Figure 1) and incomes rose steadily towards the EU average (Figure 2, panel A). The catch-up was facilitated by a relatively skilled labour force and a relatively modern industrial base. Production was reoriented to new markets in Europe, while Slovenia remained a competitive provider of goods and capital to the countries in the Balkans. Significant structural reforms paved the way to European Union (EU) accession in 2004 and euro adoption in 2007.

2. However, in the run up to the 2008 crisis, easy and cheap wholesale credit raised by Slovenian banks abroad, overly optimistic growth expectations and mispriced risk taking led to an investment boom in construction and much of the corporate sector. In addition, the optimism facilitated highly leveraged management buyouts, where internal managers took out risky loans to buy ownership stakes in companies. The resulting high indebtedness made corporates and banks vulnerable to changes in market conditions. Adjustment was also complicated by rigidities in labour and product markets and weak corporate governance, amid widespread state ownership. The subsequent drop in output was one of the largest in the OECD and the living standards still remain below the pre-crisis levels (Figure 2, panel B). GDP per capita in purchasing power parity in 2014 was still more than $8 \%$ lower than in 2008. Recovery has been slow, and despite some recent reforms many of the structural problems remain un-addressed.

\section{Figure 1 Growth was strong after independence}

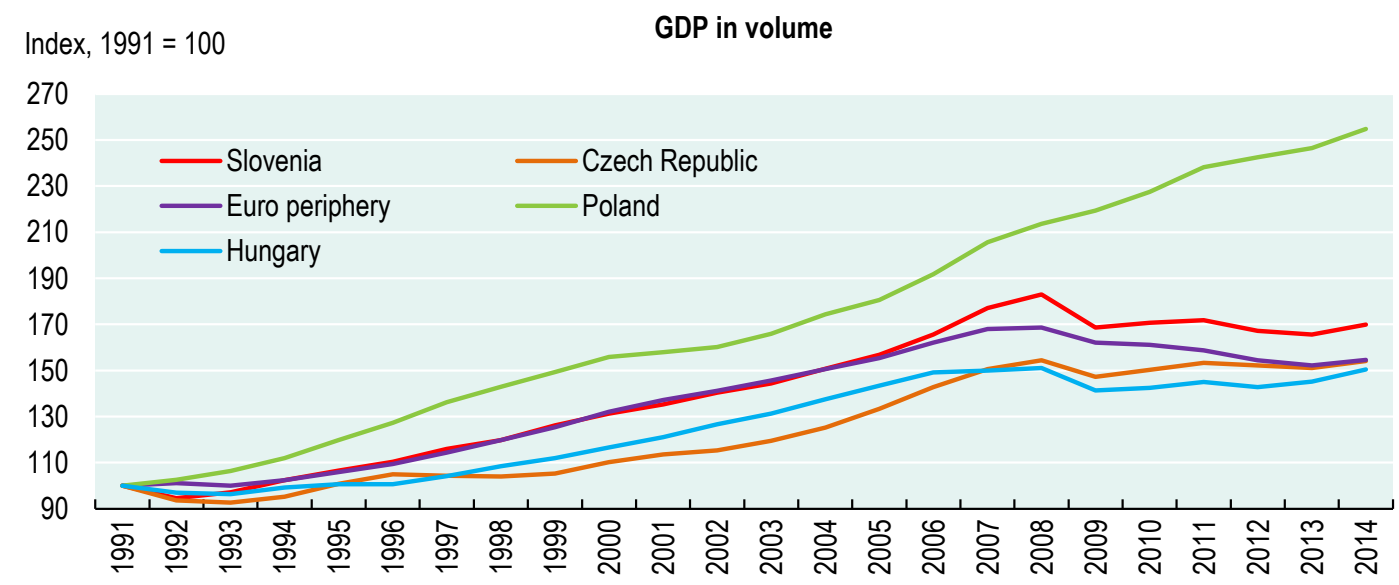

Source: OECD Economic outlook 96 database.

1. Urban Sila is an economist working in the Economics Department, on the Slovenia desk, Nataša Jemec is an economist in the Economics Department, seconded for one year form the Bank of Slovenia, Hermes Morgavi is a statistician working on the Slovenia desk. This paper is extracted from Chapter 1 of the 2015 OECD Economic Survey of Slovenia, published in May 2015 under the authority of the Economic and Development Review Committee (EDRC). The authors especially thank Piritta Sorsa, Robert Ford, Álvaro Pereira, colleagues from other relevant OECD departments and Slovenian government officials for valuable comments on earlier drafts and Anthony Bolton for editorial assistance. 
Figure 2 Rapid catch-up stalled after the crisis
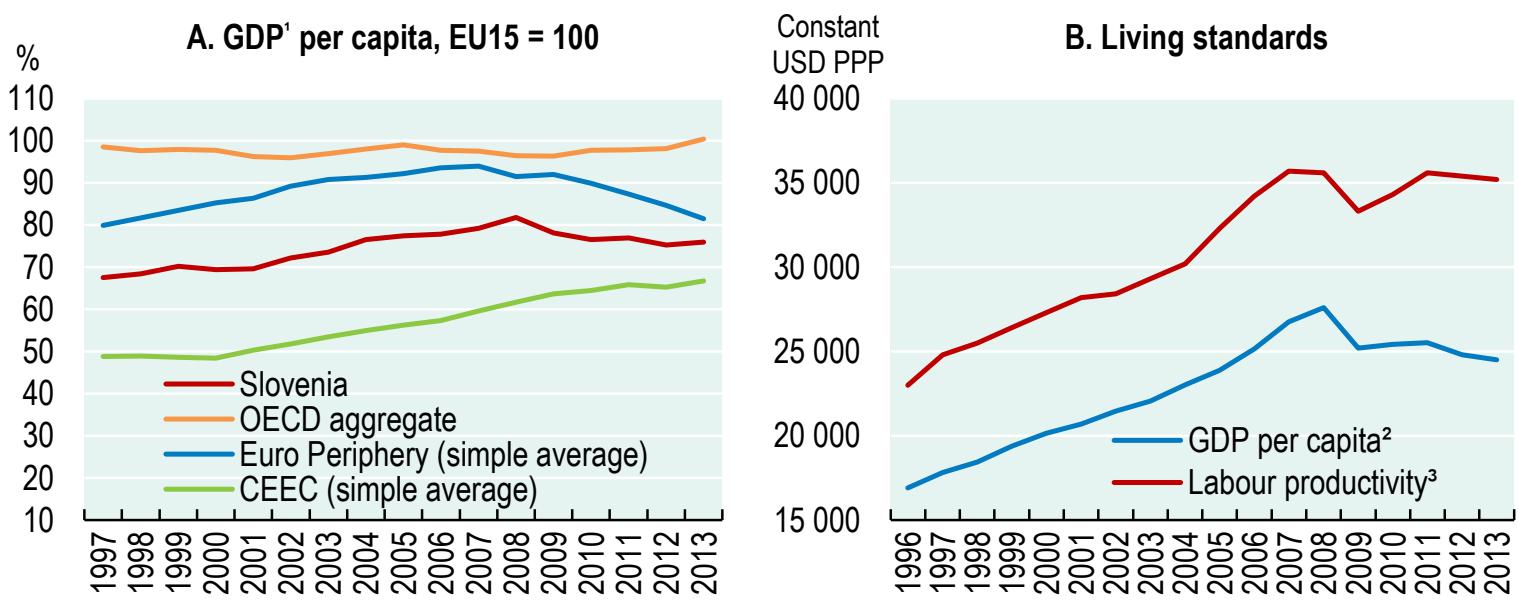

Note: CEECs include Poland, Hungary, Slovak Republic and Czech Republic; Euro Periphery includes Spain, Portugal, Greece and Ireland.

1. GDP in million USD, current prices, current PPP per thousand persons/thousand hours worked.

2. GDP in USD constant prices, constant PPP (base year 2005).

3. Labour Productivity measured as GDP per thousand hours.

Source: OECD Productivity database.

3. Labour productivity - measured in GDP per hour worked - also grew strongly before the crisis and dropped substantially in 2008. It has, however, by now recovered to the pre-crisis levels. These positive developments reflect large adjustments in the use of labour. After the crisis there was a rise in the unemployment rate, but also a sizeable fall in the labour force participation and adjustments in hours worked by the employed workers (Figure 3). To turn around the negative trend in living standards it will be therefore important to revive growth in labour utilisation, while sustaining productivity growth.

Figure 3 There has been large adjustment in labour utilisation after the crisis

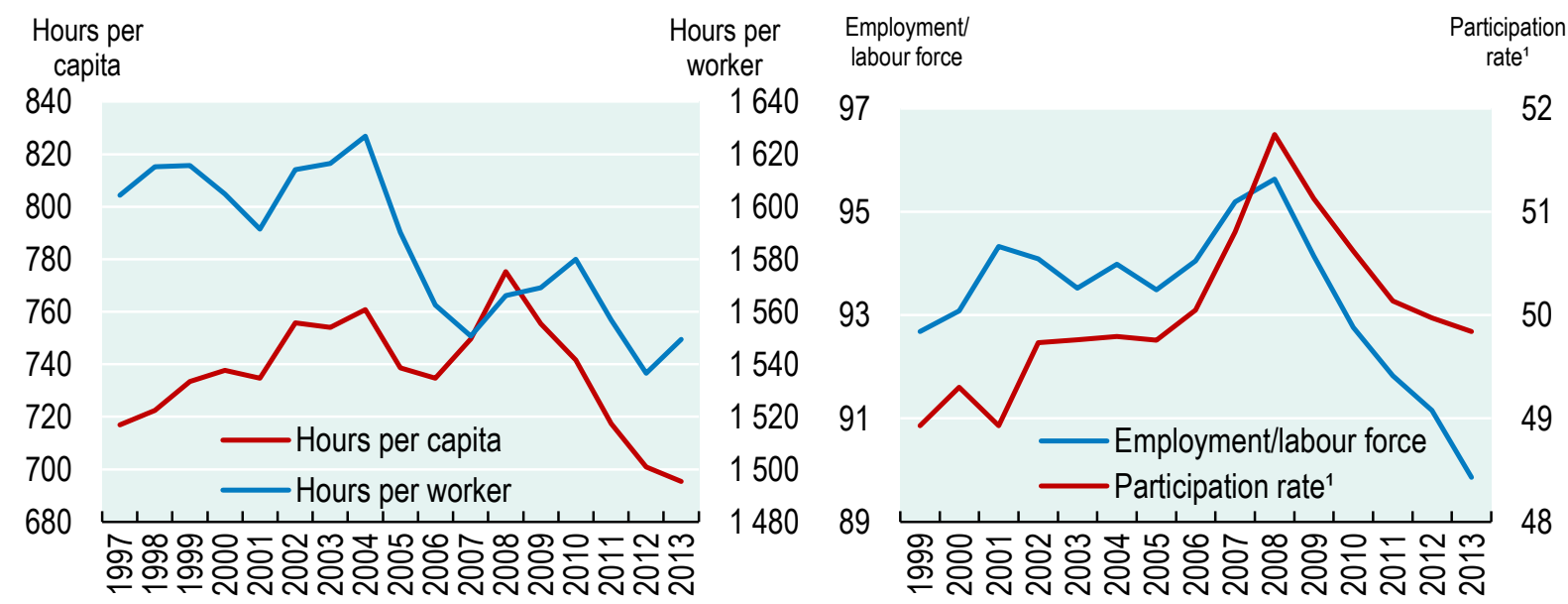

Note: Hours per capita can be decomposed into hours per worker (total hours / total employment), participation rate (labour force / population) and employment / labour force. The last term is equivalent to (1 - unemployment rate).

1. The participation rate refers to the ratio of the total labour force (aged 15 and over) to the total population.

Source: OECD Level of GDP per capita and productivity database, for Panel A; and OECD Short-Term Labour Market Statistics database, for Panel B. 
4. Prior to the crisis productivity in terms of value added per labour input grew in most sectors of the Slovenian economy (Figure 4, panel A). However, productivity is strikingly low compared to the EU15 average in some specific sectors such as agriculture, mining and utilities (Figure 5). Productivity is also low in financial and insurance services, and professional services (especially in administrative and support service activities). After the crisis in 2008 all sectors except manufacturing, and mining and utilities turned to a negative productivity growth, measured as gross value added (GVA) per worker. Yet, in terms of GVA per hour, most sectors, except construction, for example, still experience positive productivity growth, reflecting more extensive use of labour (Figure 4, panel B).

Figure 4 Growth in value added per worker turned negative in most sectors, while value added per hour continued growing

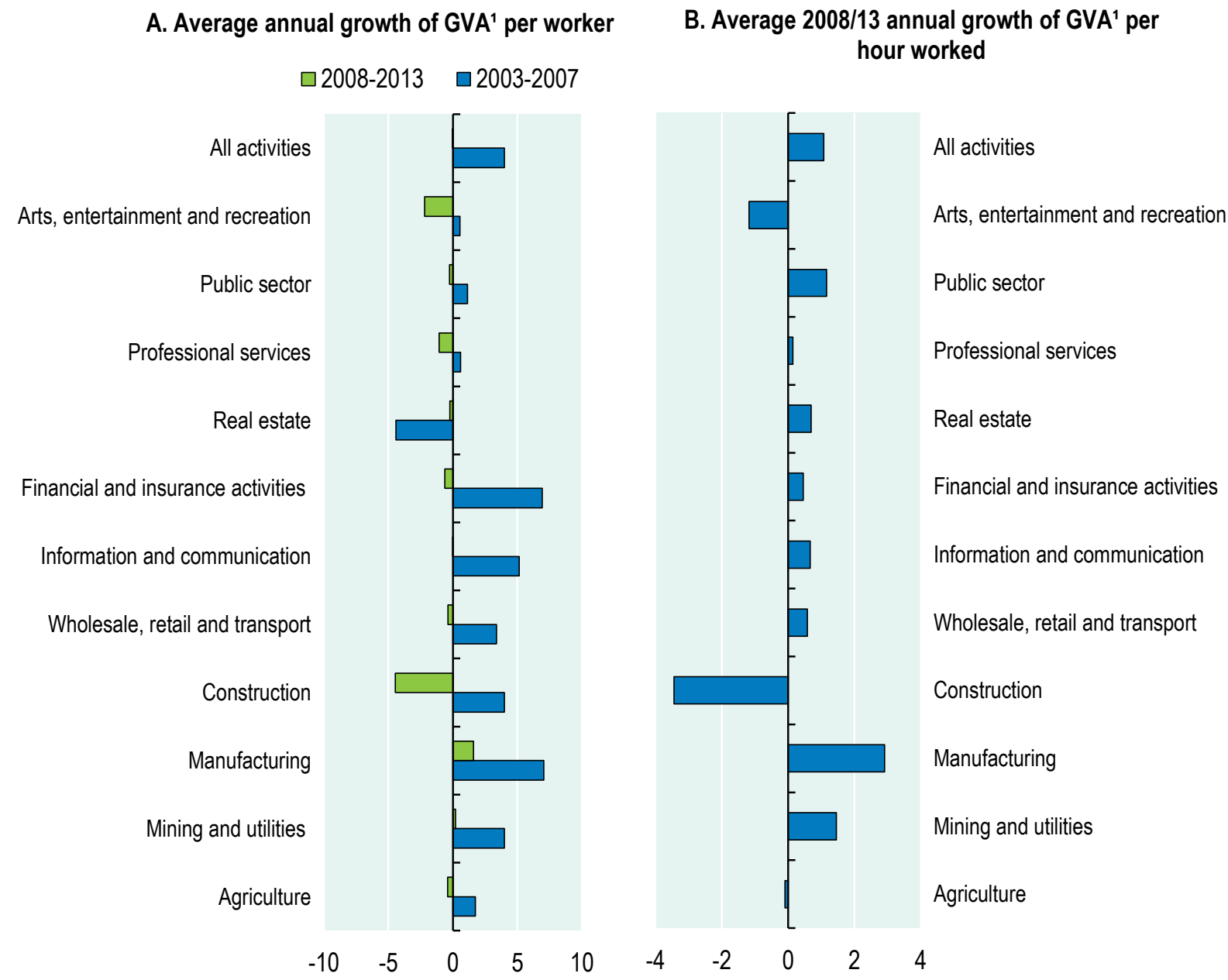

1. GVA in volume terms in million euros per thousand workers (reference year 2005).

Source: Eurostat National Accounts detailed breakdowns. 


\section{Factors contributing to growth}

5. GDP growth can be decomposed into contributions from various factors of production: capital deepening, growth in the quantity of labour input, labour quality (human capital) and the residual - total factor productivity (TFP) growth (see Dall'Orso and Sila (2015) for a more detailed description of the methodology).

\section{Figure 5 There is scope to improve labour productivity in several sectors}

Gap from the EU15, in \% (2013)

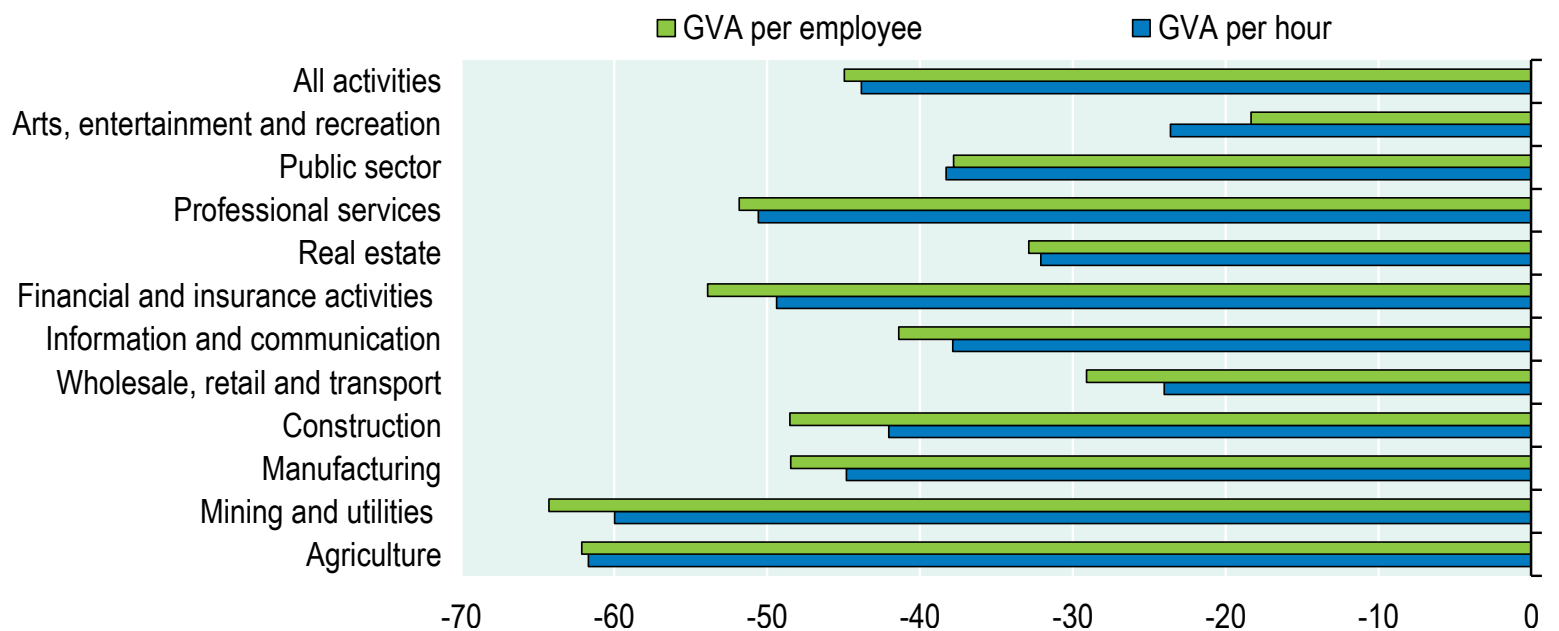

Note: Gross value added (GVA) per employee measured as GVA in current prices, basic prices, million euros per worker (total employment). GVA per hours measured as GVA in current prices, basic prices, million euros per thousand hours. Note that there is a sizable difference in the productivity gap between this measure and the GDP per capita measure in the previous section. The difference stems from two factors - one is that GDP per capita is measured in PPP. The other one is that GVA is measured at basic prices, thus excluding indirect taxes but including subsidies on products.

Source: Eurostat National Accounts detailed breakdowns.

6. The growth accounting exercise shows that capital deepening and total factor productivity were Slovenia's main sources of economic growth from 1997 to 2007. After 2008, the GDP growth rate became negative, mainly due to falling labour quantity and negative TFP growth (Figure 6 and Table 1), while capital services and human capital contribution to GDP growth remained positive, albeit lower than before. Interestingly, TFP contribution started declining already in the year 2005, 3 years before the crisis, at the time of a steep rise in labour utilisation. This corroborates the argument put forward in the 2009 Economic Survey that the Slovenian economy was showing signs of overheating. In particular, after the euro area entry in 2007 inflation peaked at the highest level within the euro area and unemployment fell significantly below the natural rate. 
Figure 6 Contribution of factors ${ }^{1}$ to GDP growth

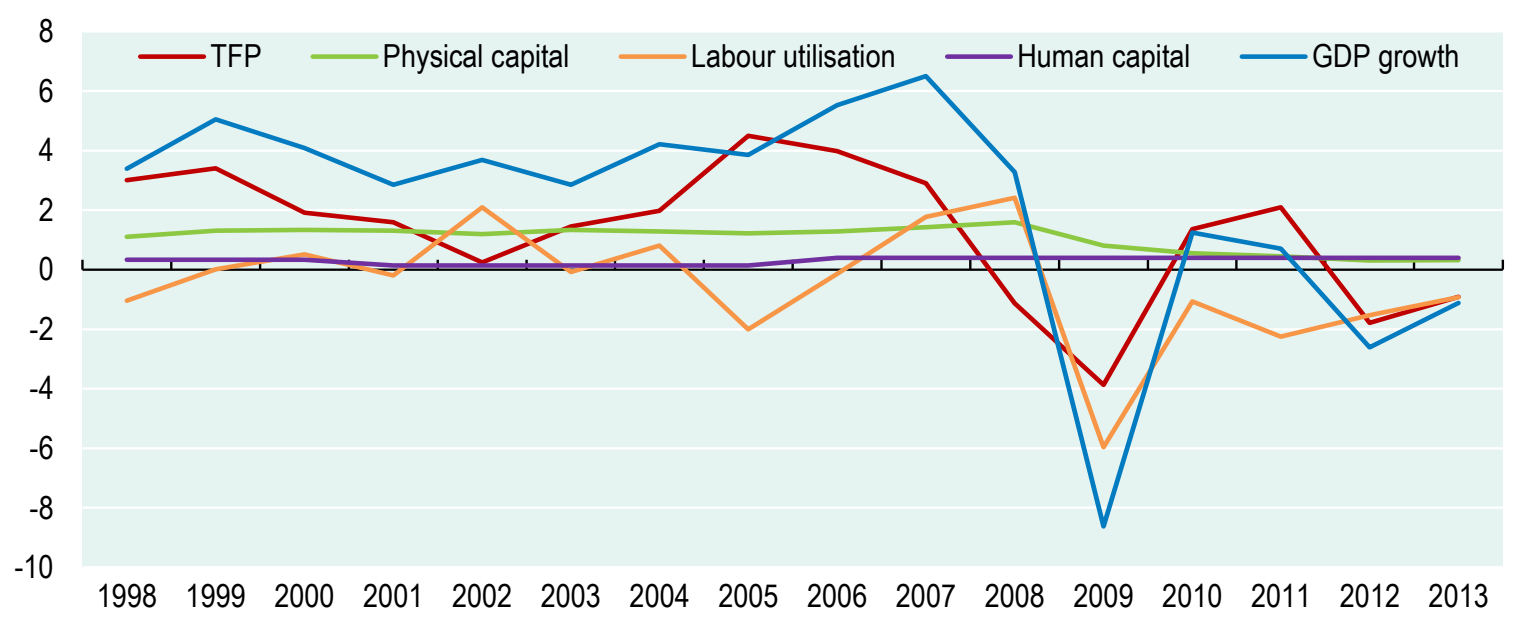

1. Human capital index is measured by average years of schooling; Labour quantity is measured in total hours worked; Physical capital is measured in volumes of capital stocks; TFP, Total Factor Productivity is calculated as a residual.

Source: OECD National Accounts Statistics database and OECD calculations.

Table 1 1997/2007 Growth accounting in CEECs ${ }^{1}$, Euro Periphery ${ }^{2}$ and EU3 ${ }^{3}$

Average annual growth in percent ${ }^{4}$

\begin{tabular}{lcccc|cccc}
\hline & \multicolumn{4}{c}{$1997 / 2007$} & \multicolumn{4}{c}{$2008 / 2013$} \\
\cline { 2 - 8 } & Slovenia $^{5}$ & CEEC $^{6}$ & EU3 $^{6}$ & $\begin{array}{c}\text { Euro } \\
\text { Periphery }\end{array}$ & Slovenia $^{5}$ & CEEC $^{6}$ & EU3 $^{6}$ & $\begin{array}{c}\text { Euro } \\
\text { Periphery }^{6}\end{array}$ \\
\hline GDP growth & 4.395 & 4.078 & 2.421 & 4.267 & -1.107 & 1.076 & 0.194 & -1.968 \\
human capital & 0.25 & 0.374 & 0.858 & 0.614 & 0.398 & 0.264 & 0.81 & 0.392 \\
labour utilisation & 0.184 & 0.014 & 0.275 & 1.258 & -1.481 & -0.209 & 0.149 & -1.625 \\
physical capital & 1.339 & 1.83 & 0.694 & 1.959 & 0.693 & 1.545 & 0.509 & 0.802 \\
TFP & 2.621 & 1.861 & 0.595 & 0.436 & -0.717 & -0.523 & -1.274 & -1.536 \\
\hline
\end{tabular}

1. CEECs include Poland, Hungary, Slovakia and Czech Republic.

2. Euro Periphery includes Spain, Portugal, Greece and Ireland.

3. EU3 includes France, Germany and United Kingdom.

4. Geometric average.

5. Average of 1998/2007 because of missing values for 1996

6. CEEC, EU3 and Euro Periphery values are simple averages.

Source: OECD National Accounts Statistics and own calculations.

7. Among all countries included, the contribution from human capital before the crisis was the lowest in Slovenia (Table 1), pointing to potential weaknesses in the education and training systems. Since 2008, the GDP growth rate is lower in Slovenia compared to other Central and Eastern European countries (CEECs) mainly due to a dramatic fall in labour quantity contribution. The contribution from capital deepening in Slovenia has also dropped, reflecting lower investment. The drop in the TFP contribution to growth was sizeable in Slovenia, although its contribution is less negative than in the euro periphery countries. Thus, to return to growth, Slovenia needs to regain the TFP growth, together with higher labour participation and renewed investment cycle into physical capital. In the longer term, growth could also be better supported with increases in human capital. 
8. Before the crisis, Slovenia experienced growth in productivity (both TFP and labour productivity), while in the last quarters of 2008 the country suffered from an unprecedented productivity drop and Slovenia remained in recession for a prolonged period. The interesting question is whether the crisis led to structural changes that undermine productivity growth in the future. If productivity growth has indeed shifted down permanently, this would have important consequences for long-term economic performance. Dall'Orso and Sila (2015) test this (see also Annex 2) using time series analysis and stability diagnosis techniques to detect potential structural breaks, but evidence is inconclusive. The analysis identifies four or five break dates in the 1997-2013 period. In addition, there is weak evidence that in 2011Q4 there was another structural break in productivity, bringing average productivity growth down again. Nevertheless, it cannot be concluded that the break identified in 2011Q4 and the lower average growth thereafter imply that productivity growth has come down more permanently.

\section{External sector, global value chains and competitiveness}

9. Slovenia is an export oriented economy with exports representing more than $70 \%$ of GDP. The most important export articles are machinery, road vehicles and pharmaceutical products. In the pre-crisis period (2004-2007) Slovenia's exports grew rapidly at an average rate of $12 \%$ per year in volume terms (Figure 7). The crisis hit hard, with exports falling by $20 \%$ from 2008q1 to 2009q2 (peak to trough number), partly due to the country's export specialisation in cyclically sensitive goods, such as automotive components (OECD, 2011a). There has been a recovery in exports since then, but the recovery has been slow in comparison to benchmark economies (Figure 8). Slovenia's cost competitiveness and export market performance deteriorated and still lag behind peers (Figures 9 and 10). In the second half of 2014, however, competitiveness started improving and Slovenia has gained market shares. The tradable part of the economy, and manufacturing in particular, has made considerable unit labour cost (ULC) adjustments since 2010. And while in previous years cost competitiveness improved mainly owing to the adjustments in employment and earnings, in 2014 improvements have been mostly due to rises in value added (IMAD, 2014a).

\section{Figure 7 Slovenia's exports have been growing steadily}

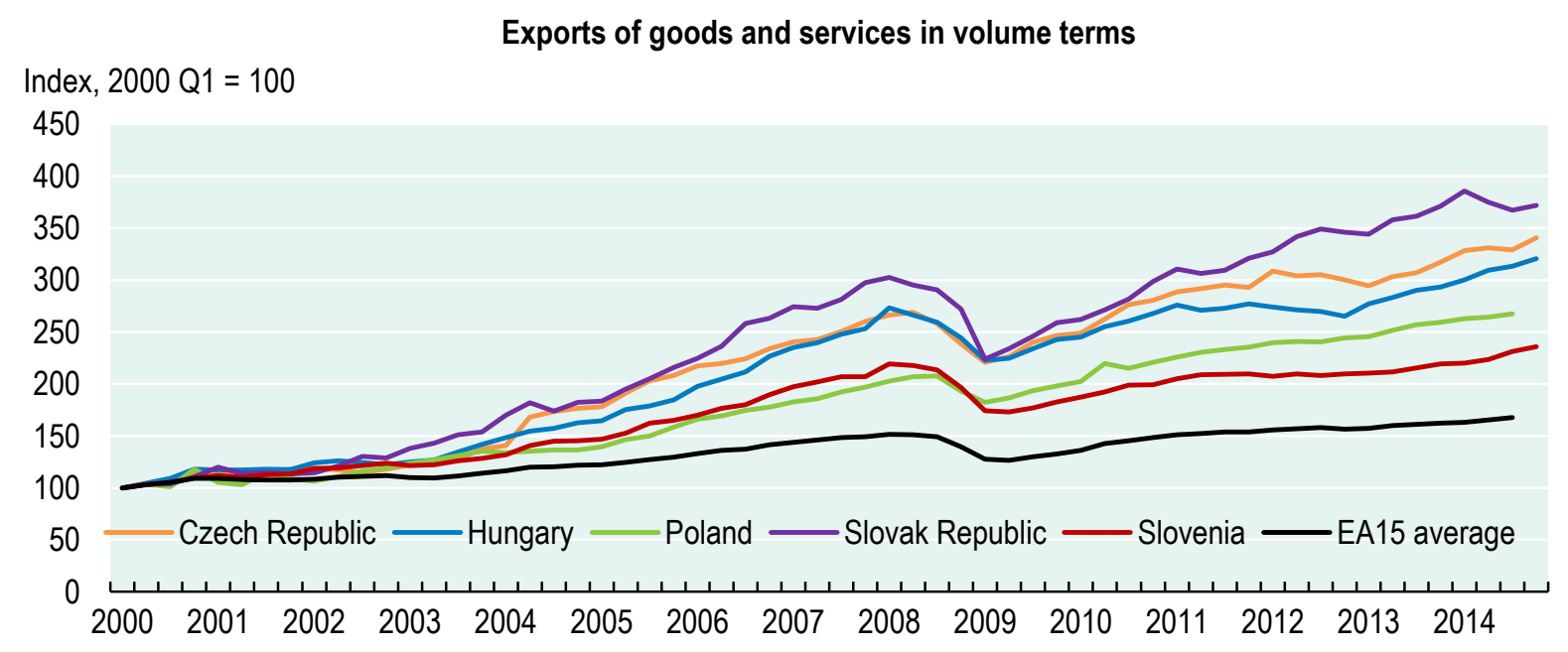

Source: OECD Economic outlook 96 database. 
Figure 8 In the post-crisis period Slovenian exports have under-performed

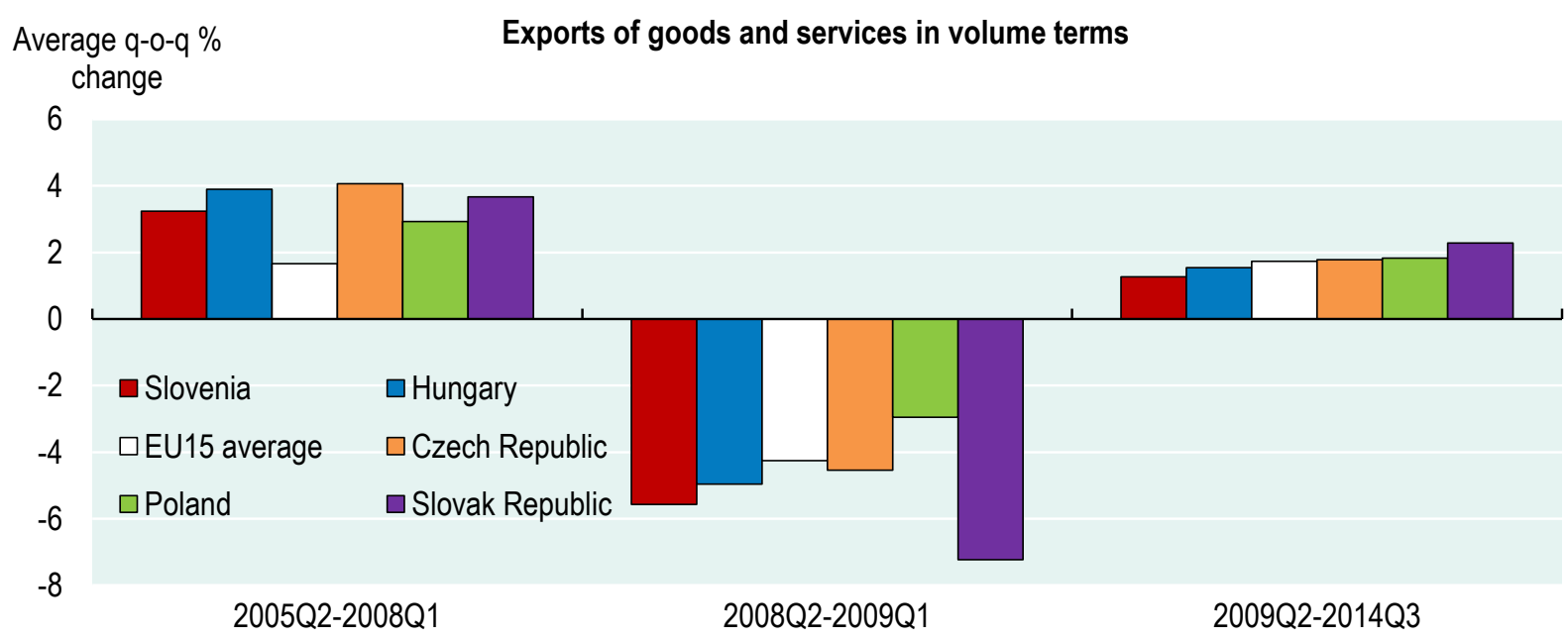

Source: OECD Economic outlook 96 database.

Figure 9 Slovenia's improvements in cost competitiveness lag some peers

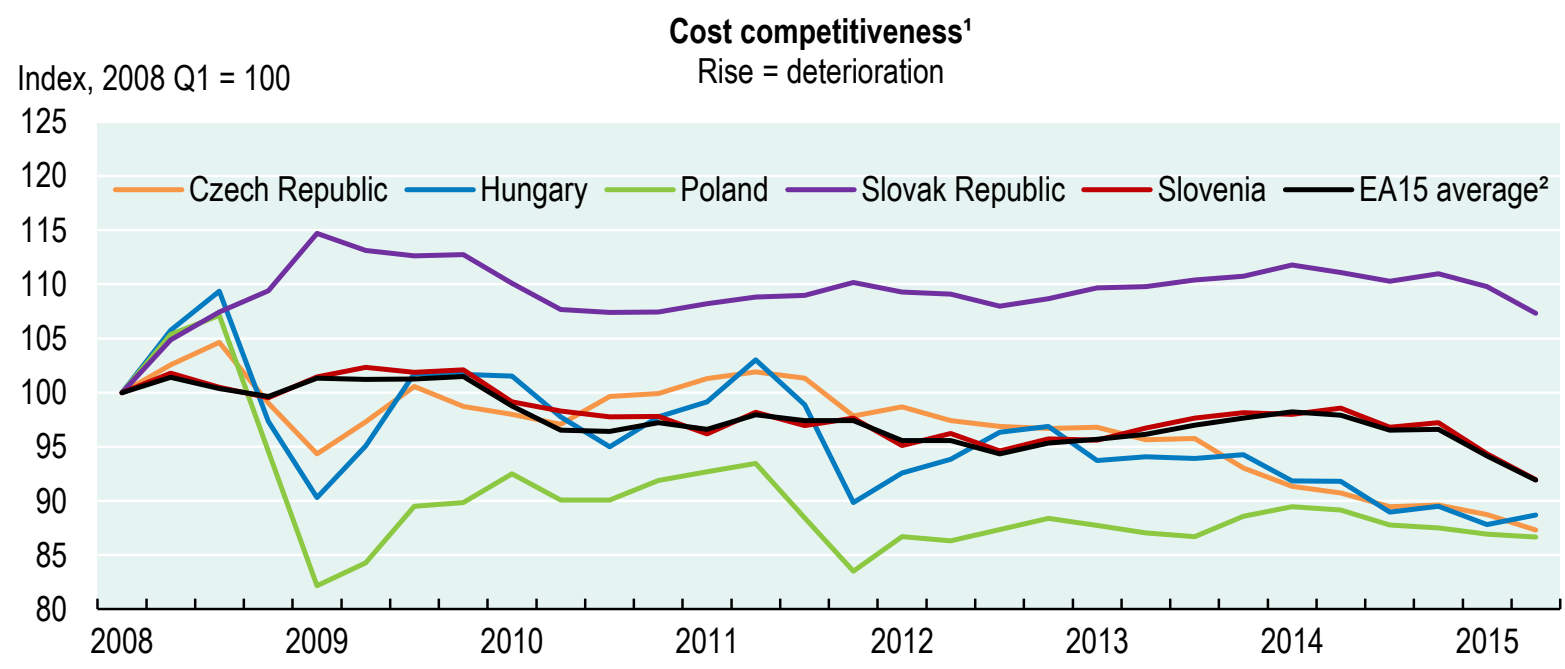

1. Real effective exchange rates based on unit labour costs for total economy.

2. Data refer to the weighted unconsolidated average across the EA15 countries.

Source: OECD Economic outlook 96 database. 
Figure 10 Export market performance stagnated, but there have been improvements recently

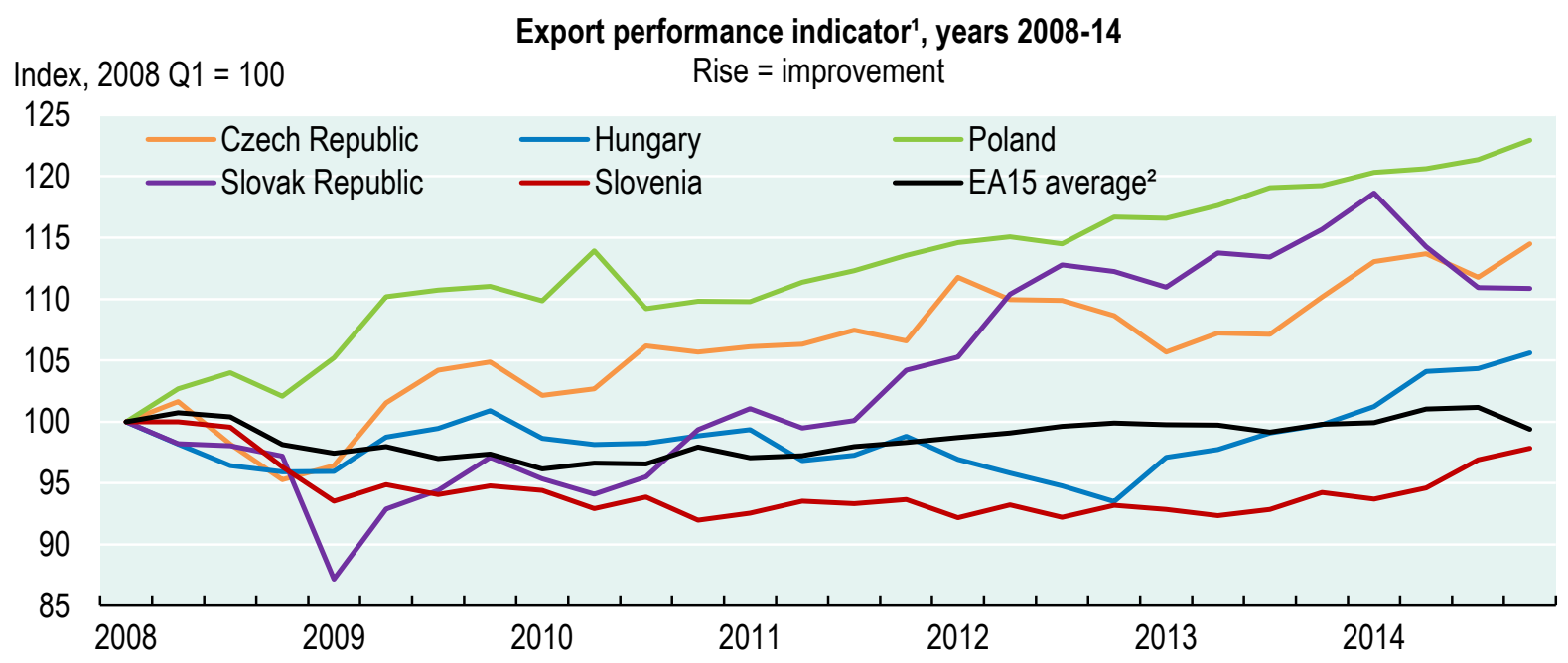

1. Export performance is measured as actual growth in exports relative to the growth of the country's export market, which represents the potential export growth for a country assuming that its market shares remain unchanged.

2. Data refer to the weighted unconsolidated average across the EA15 countries.

Source: OECD Economic outlook 96 database.

10. Slovenia has increased slightly the share of domestic value added incorporated in gross exports, indicating that it now benefits more from trade, but the share remains relatively low compared to most advanced economies (Figure 11). As many other small economies, Slovenia has a high participation in global value chains (GVCs) (Figure 12), primarily driven by the use of foreign intermediates (backward participation) in Slovenia's exports (OECD, 2013a). High backward participation is typical in the manufacturing sector, while services typically show a higher forward participation.

Figure 11 The share of domestic value added in gross exports is still low

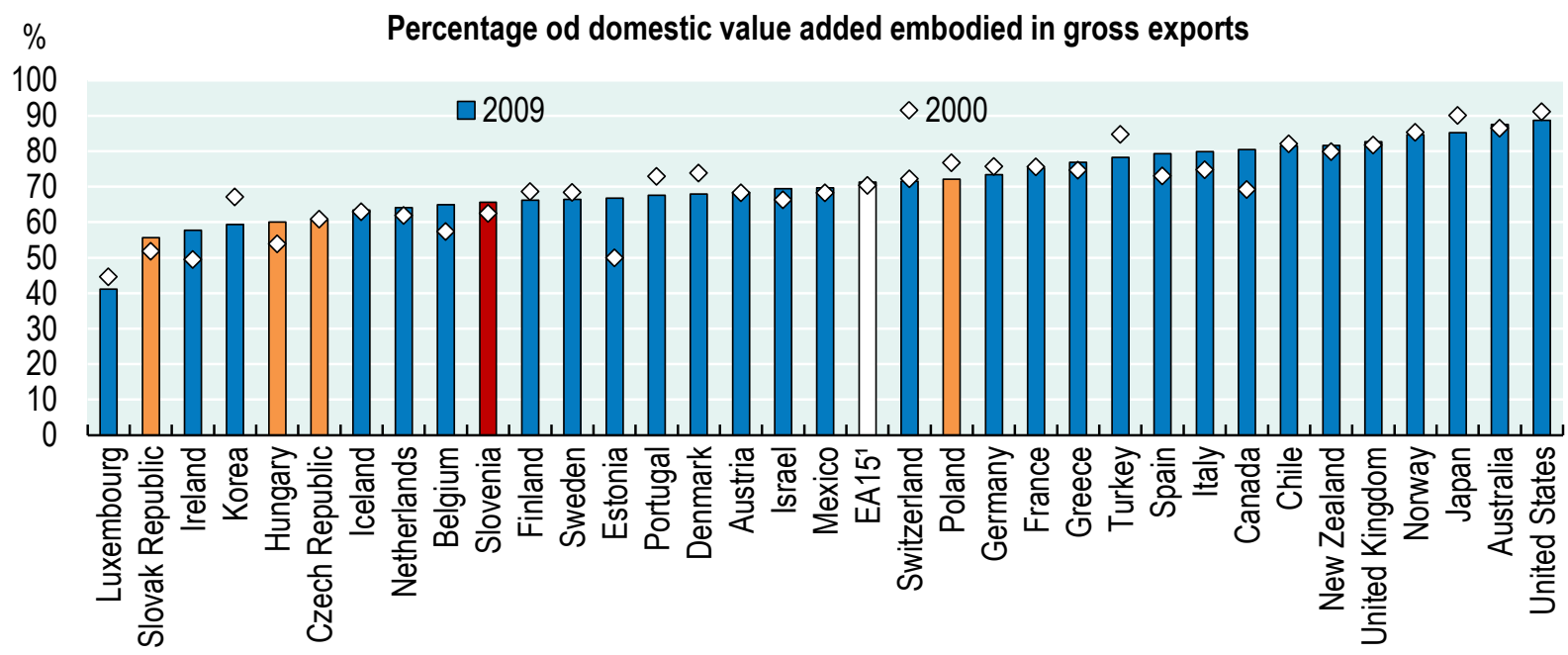

1. Data refer to the weighted unconsolidated average across the EA15 countries.

Source: OECD-WTO Trade in Value Added (TiVA) database. 
Figure 12 Slovenia has a high GVC participation index due to high backward participation

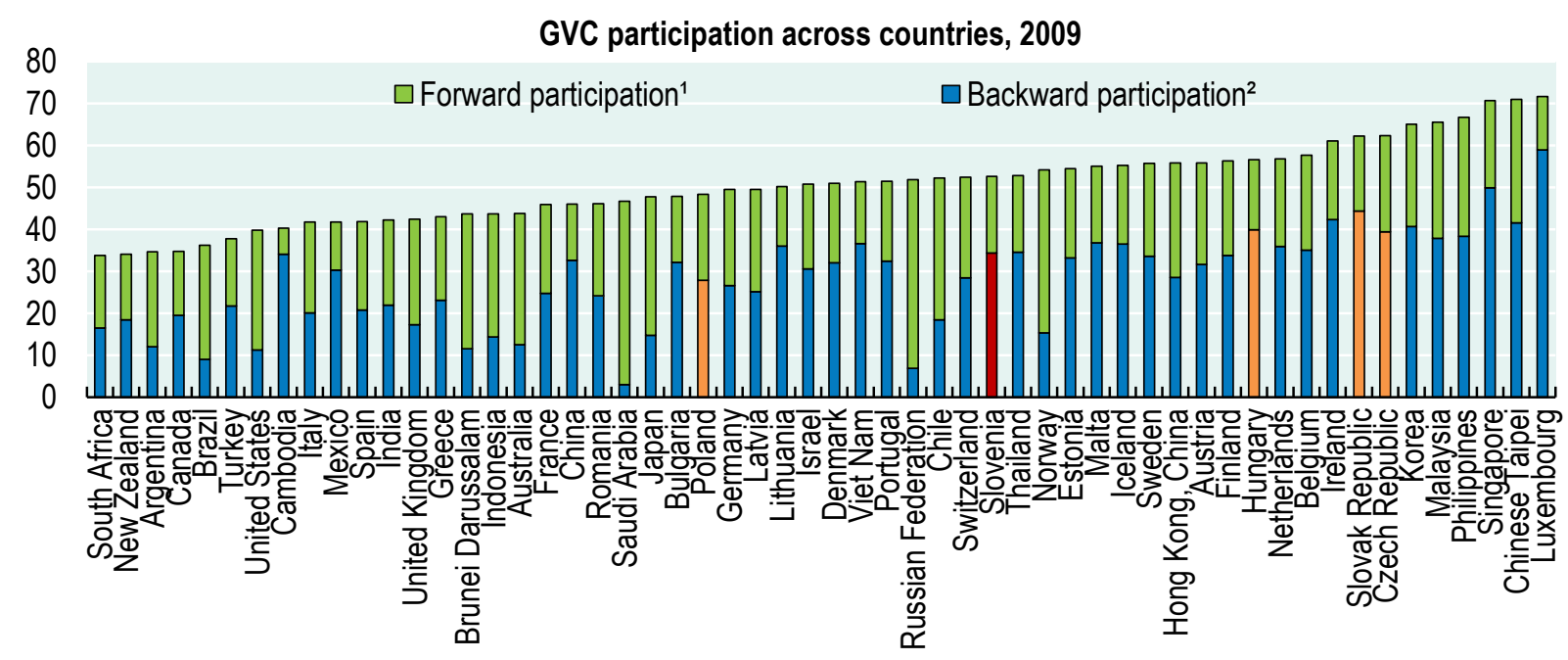

1. The indicator provides the share of exported goods and services used as imported inputs to produce other countries' exports. This indicator gives an indication of the contribution of domestically produced intermediates to exports in third countries.

2. The indicator measures the value of imported inputs in the overall exports of a country (the remainder being the domestic content of exports). This indicator provides an indication of the contribution of foreign industries to the exports of a country by looking at the foreign value added embodied in the gross exports.

Source: OECD Global Value Chains indicators - May 2013.

11. The share of services in total exports is high compared to other CEECs, and has been increasing, but remains below the EA15 average. According to the OECD Services Trade Restrictiveness Index (STRI), Slovenia is open to services trade (Figure 13). In most of the services sectors Slovenia shows lower restrictions to trade than OECD and EA15 averages. This is good as services normally bring higher value added in trade compared to manufactured goods. In Slovenia, services account for about $20 \%$ of gross exports, but they represent $42 \%$ of value-added exports.

Figure 13 Slovenia is open to services trade

Services Trade Restrictiveness Index (STRI)

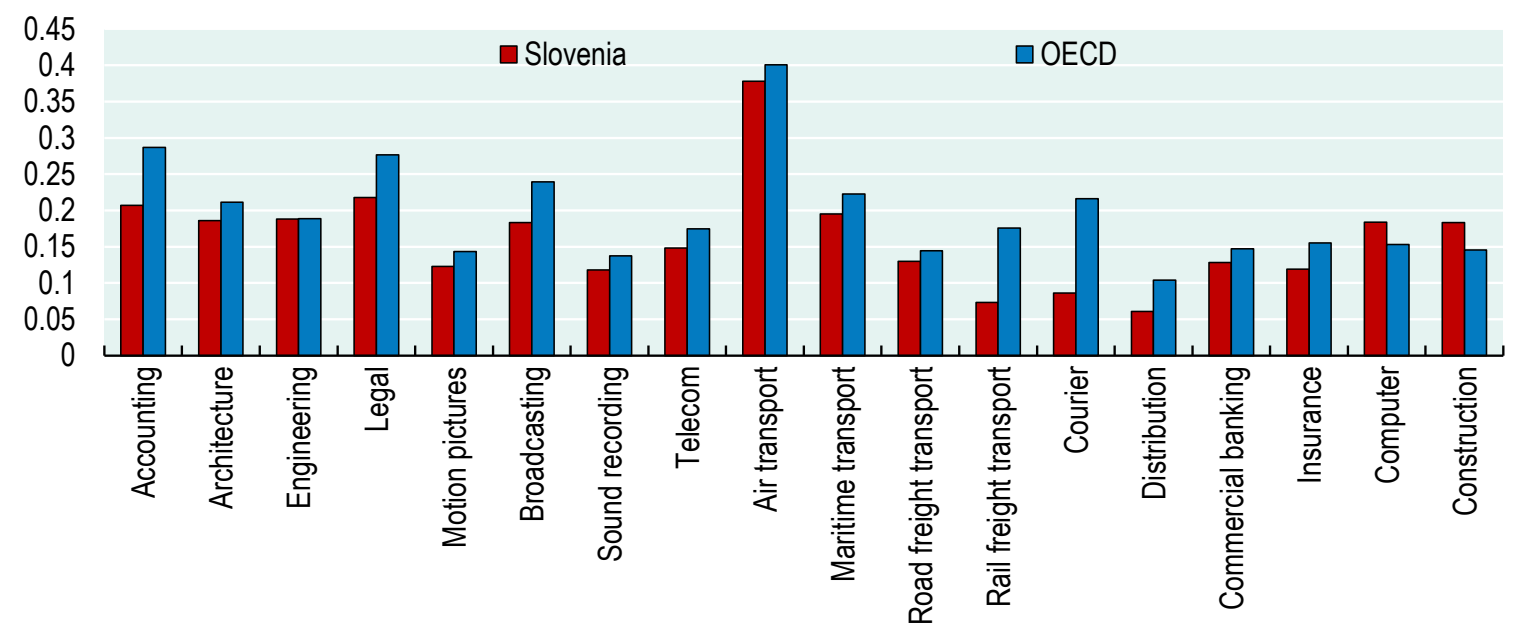

Note: The STRI takes the value from 0 to 1 , where 0 is completely open and 1 is completely closed. It is calculated on the basis of information in the STRI database which reports regulation currently in force.

Source: OECD Services Trade Restrictiveness Index database. 
12. Exports of goods are mainly concentrated in medium-high and medium-low technology industries (Figure 14), with biggest part of exports being intermediate goods. Slovenia evolved from being a net exporter of low and medium-low technology goods to a net exporter of high and medium-high technology goods (see Box 1). High-tech exports represent an important channel for learning by exporting and several studies show that starting to export helps boost innovation (Lovea and Ganotakisb, 2013; Hausmann et al., 2011). Moreover, high-tech firms tend to attract more FDI and at the same time, in presence of FDI, they grow faster (Damijan, Kostevc and Rojec, 2013). Further increases of high-tech exports would therefore help future growth.

Figure 14 High-technology goods have increased their weight in export

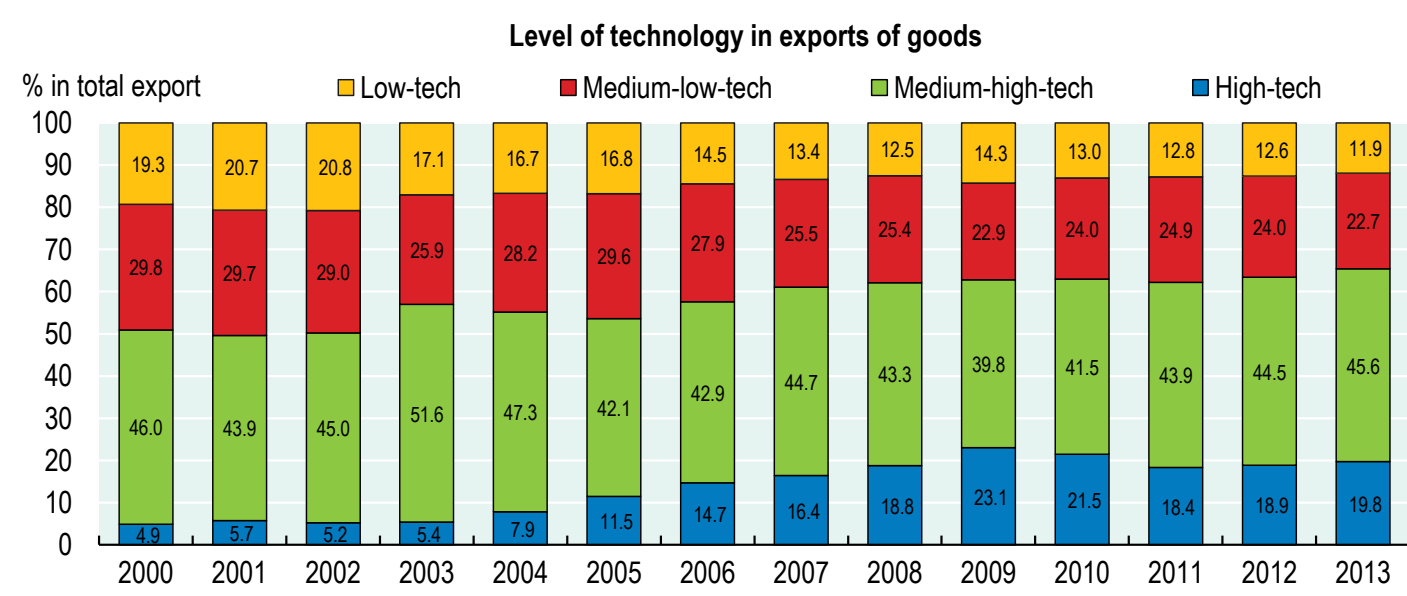

Source: OECD STAN Bilateral Trade in Goods by Industry and End-use database.

\section{Box 1 High-technology manufacturing in Slovenia}

Share of the high- and medium-high technology manufacturing in total manufacturing GVA has risen from about $30 \%$ of total GVA in manufacturing in 1996 to $45 \%$ in 2012, which is higher than in some other CEEC peers, but lagging behind high performers such as Ireland and Germany (Figure 15). The rise can be explained by a growth in value added by pharmaceutical companies and a decrease in the contribution of low-technology industries, especially textile, wearing apparel, leather and furniture, due to bankruptcies.

\section{Figure 15 Share of high and medium technology manufacturing is relatively high}

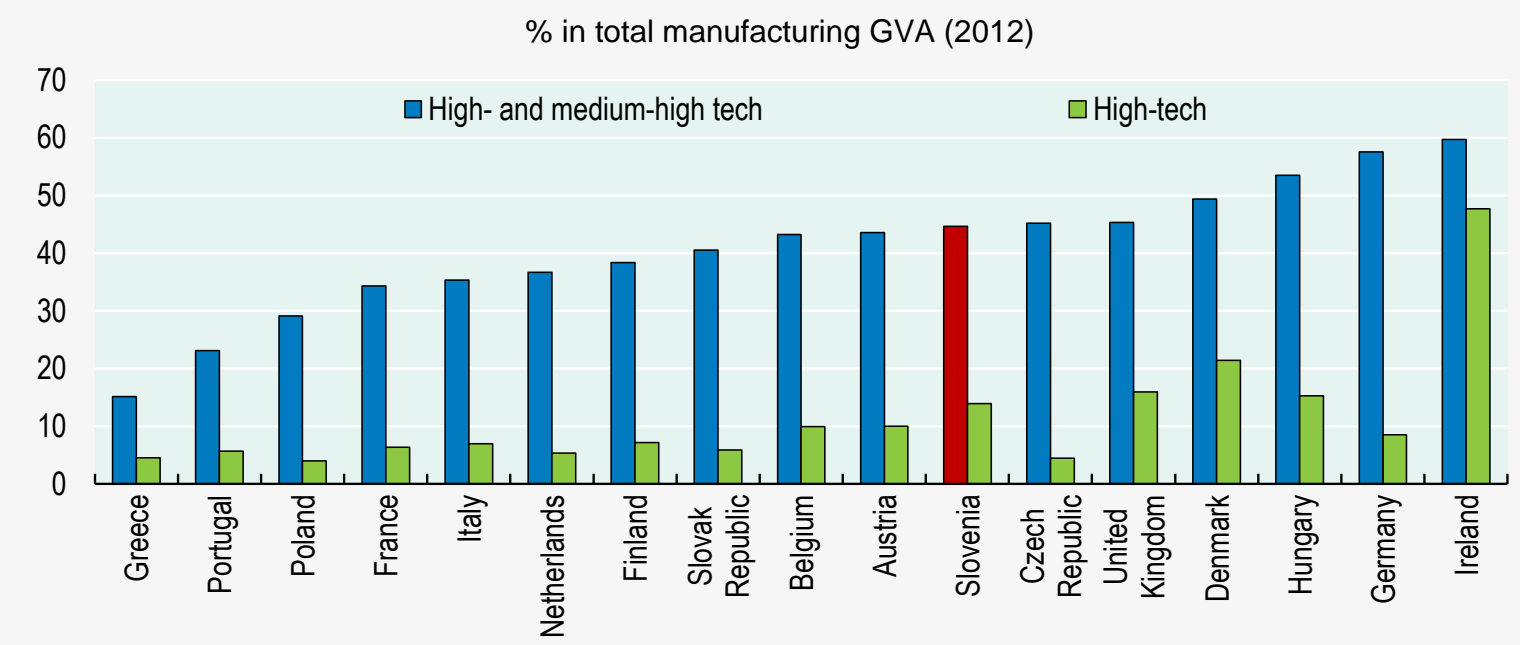

Note: GVA in basic prices and in current prices. Based on Eurostat aggregation of the manufacturing industry according to technological intensity, based on NACE Rev. 2, 2 digit level. For countries where data is not available for 2012, 2011 numbers are used.

Source: Eurostat and OECD calculations. 
(Box 1- continued)

Improvement in overall business environment can contribute to increasing further the role of high-tech manufacturing, and thereby increase productivity and growth in Slovenia. In the last two decades productivity growth has been fastest in the high-technology manufacturing by a high margin (Table 2) and the level of productivity in the high-technology sectors is the highest too - about 2.6 times the level in the low-tech manufacturing (Figure 16, panel A). High productivity also brings higher wages; in the high-tech manufacturing wages are about 2 times higher than in low-tech manufacturing (Figure 16, panel B).

Slovenia is relatively competitive in high and medium high technology products as indicated by the high contribution of these products in the trade balance. In 2011 , these products contributed $6 \%$ to the trade balance, as compared to $4.2 \%$ in the EU or $1.93 \%$ in the US (European Commission, 2013). Furthermore, the contribution has been increasing steadily in recent years.

Table 2 Productivity growth has been fastest in high-technology manufacturing

Annual \% change in GVA $^{1}$ per worker

\begin{tabular}{ccccc}
\hline & High-technology & $\begin{array}{c}\text { Medium-high- } \\
\text { technology }\end{array}$ & $\begin{array}{c}\text { Medium-low- } \\
\text { technology }\end{array}$ & Low-technology \\
\hline $1997-2007$ & 11.6 & 7.6 & 1.4 & 5.3 \\
\hline $2008-2012$ & 6.5 & 0.9 & -0.2 & 0.9 \\
\hline
\end{tabular}

1. Gross value added at basic prices, in chain linked volumes, reference year 2005.

Source: Eurostat.and OECD calculations.

Figure 16 Labour productivity and wages are higher in high technology manufacturing

\section{A. Labour productivity ${ }^{1}$ is higher in high-tech manufacturing}

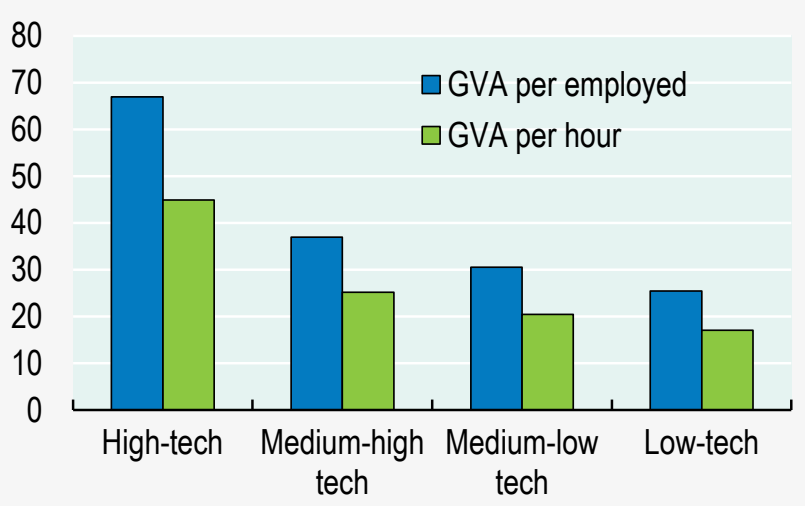

\section{B. Wages ${ }^{2}$ are highest in high-tech manufacturing}

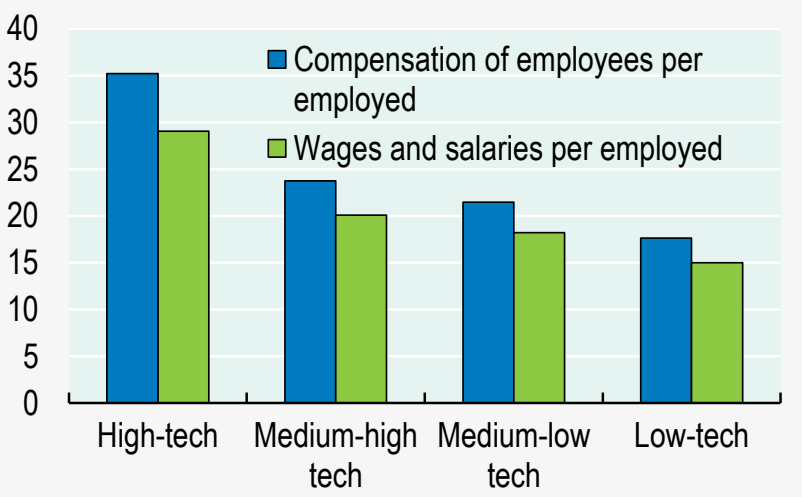

1. In 1000 euros per person employed/ 1000 hours, 2012.

2. In 1000 euros per person employed, 2012.

Note: Based on Eurostat aggregation of the manufacturing industry according to technological intensity, based on NACE Rev. 2, 2 digit level. GVA in basic prices and in current prices.

Source: Eurostat and OECD calculations. 


\section{Innovation, R\&D and entrepreneurship}

\section{Increasing innovative activity}

13. Expenditure on $R \& D$ and human resources in science and technology occupations in Slovenia is above the OECD average (Figure 17), with most of expenditure done by businesses (OECD, 2014a). Business enterprise expenditure on R\&D (BERD) has increased rapidly, to the level of Austria's and Denmark's in terms of GDP, and it is higher than in many advanced OECD countries. However, the share of industry-financed BERD has dropped in recent years, while the share of government-financed BERD has increased. Slovenia is also strong in human resources in science and technology occupations. The number of researchers and R\&D personnel has been on the rise and measured as \% of all employees it is one of the highest among the OECD countries (OECD 2014f and 2013f; SORS, 2012).

14. Compared to high R\&D expenditure, a number of innovation outcomes are low as indicated by a low number of patents, trademarks, services' share of business R\&D and a low number of innovative firms (Figure 17). The number of patents and the number of trademarks per GDP are below the OECD median. The bulk of $R \& D$ expenditure goes to technological innovations and majority of business R\&D spending is undertaken only by a few large firms (e.g. two pharmaceutical firms account for a large share) (OECD, 2012c). Services' share of business R\&D in 2011 (26\%) was low compared to their value added share (67\%). R\&D intensity in services is much lower than the OECD average. This indicates a weak drive to develop non-technological innovation (OECD, 2011a, 2013f), which should be given more focus within R\&D expenditure. The share of knowledge intensive services (e.g. financial intermediation and high-tech services) in total services exports is also small - roughly half of the share of the EU average (European Commission, 2014b).

\section{Figure 17 Slovenia does well in terms of inputs into innovation process, but innovative activity is low}

Comparative performance of national science and innovation systems, 2014

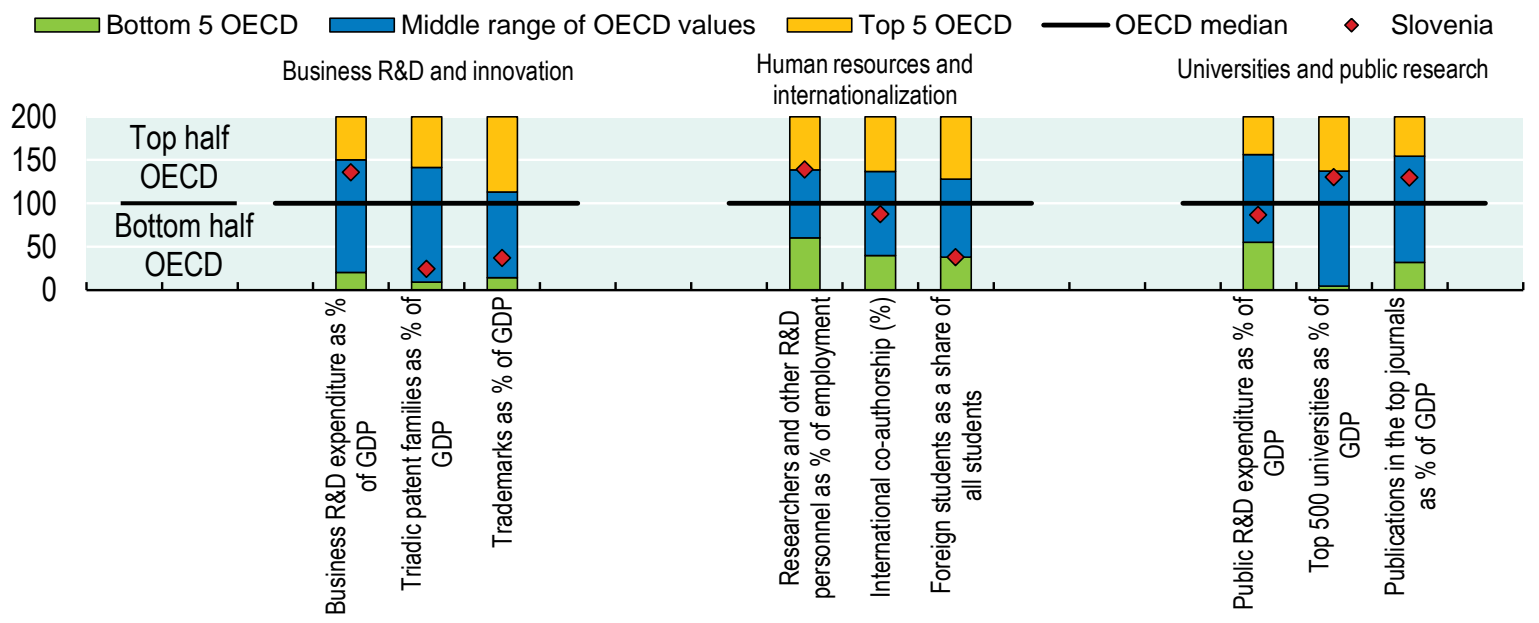

Note: Normalised index of performance relative to the median values in the OECD area (Index median $=100)$.

Source: based on OECD Science, Technology and Industry Outlook 2014 and OECD, Main Science and Technology Indicators (MSTI) Database, June 2014; USPTO Bulk Downloads: Trademark Application Text hosted by Reed Technology Information Services, OHIM Community Trademark Database CTM Download, JPO Annual Reports 2001-2013 and Graham, S., G. Hancock, A. Marco A. and Myers (2013), "The USPTO Trademark Case Files Dataset: Descriptions, Lessons, and Insights", SSRN Working Paper, http://ssrn.com/abstract=2188621; Elsevier B.V. (2014), Elsevier Research Intelligence (Scopus - Elsevier); OECD Education database; and Academic Ranking of World Universities (ARWU) (2013), "Shanghai ranking", www.shanghairanking.com. 
15. Innovative activity could be increased by higher inflows of FDI and by improvement in the overall business environment. Inflows of FDI are currently small relative to other central and eastern European countries (see below). There are three major constraints in overall business environment hindering innovation: a lack of entrepreneurial dynamism, barriers to doing business and the overly complex and opaque national innovation policy (OECD, 2011a). Improvement in the overall business environment that would better support innovation therefore involves strengthening entrepreneurship education in schools, improvement in the support environment for enterprises, investing in the national innovation system and strengthening links between universities and business.

\section{Improving entrepreneurial dynamism}

16. Birth and death rate of companies are low compared to other OECD countries and firms have a high survival rate (OECD, 2014c). This may be related to stigma in the case of failure, since Slovenia has the lowest number of adults who think that entrepreneurs who fail deserve a second chance (OECD, 2013h), as well as to protracted insolvency procedures. The legacy of the previous economic system may have left some generations without entrepreneurial culture. Prior to the transition to the market economy in 1990, policy makers' systematically shut out entrepreneurial considerations in policy making (EIU, 2009), which may have affected attitudes. Even today, less than $40 \%$ of Slovenian adults consider image of entrepreneurs as broadly favourable, one of the lowest among the 33 surveyed countries (OECD, 2013h, European Commission, 2013). Additionally, the share of adults who recognize business opportunities was only $17 \%$ in 2014, which ranks Slovenia to 68th place out of 70 countries (Global Entrepreneurship Monitor, 2015a).

17. The lack of entrepreneurship education may also affect entrepreneurial activity. Almost half of adults consider that school education did not help in developing sense of initiative and entrepreneurial attitude. Moreover, almost $60 \%$ think that schooling did not provide the skills and know-how needed to start a business (OECD, 2013h, European Commission, 2013). Opportunities for receiving entrepreneurship education in schools, universities and research institutions are still sparse, despite the gradual phasing-in of entrepreneurship studies into the school system through pilot projects since 2008 (OECD, 2011a). Entrepreneurial dynamism could be fostered by strengthening entrepreneurship education in schools and reforming the education system so that it encourages creativity and entrepreneurial drive.

\section{Start-up entrepreneurship is rising}

18. Start-up companies can play an important role in supporting innovation and business creation. They tend to be closely connected to knowledge institutions (e.g. universities) and therefore promote knowledge flows. The number of start-up companies in Slovenia is increasing faster than the average of all companies in the economy and is creating new jobs with high value added. According to Global Entrepreneurship Monitor 2014 (2015b) Slovenia ranks $7^{\text {th }}$ among 44 countries by innovativeness of earlystage entrepreneurs. In recent years support environment has improved and a large number of new measures have helped start-up entrepreneurs, including the reduction of administrative burdens to establish a start-up, subsidies for the start-up of innovative companies, a voucher system of training for potential entrepreneurs and rising enterprises, business incubators, technology parks and business accelerators with financial, mentoring, consulting and infrastructural products in one place (Ministry of Higher Education, Science and Technology, 2010; OECD, 2011a; Initiative start:up Slovenia, 2014). In the period 2013-14 the government contributed around 10 million EUR (0.03\% of GDP) in the form of subsidies for start-ups and to improve innovative support environment. 
19. To increase growth in the number of start-ups, further improvement in the support environment is needed. The entrepreneurship support in Slovenia does not differentiate between support for start-ups and other companies. This prevents the creation of a suitable and successful entrepreneurship policy and support mechanisms targeting start-up companies. In order to develop start-up ecosystem, Slovenia needs more support activities, a higher quality of already established support services and better networking with support institutions located internationally (Initiative start: up Slovenia, 2014).

20. Access to finance is another barrier for innovative start-ups and small and medium sized enterprises (SMEs). These companies tend to lack collateral, cash flow and a track record (OECD, 2013g). SMEs in Slovenia primarily depend on bank financing and since Slovenian capital market is shallow and illiquid, their sources of financing are even more limited. In line with trends elsewhere in the OECD, EU and Slovenia offer additional funds to these companies. The Slovene Enterprise Fund (SEF) and SID bank (the Slovenian development bank) offer financing for SMEs in conjunction with the commercial banks. Additional funds and instruments dedicated to financing via venture capital funds and business angels are offered by European Investment Fund and the COSME programme. However, the latter are at present unutilised (Bank of Slovenia, 2014a), possibly because firms are not familiar with their existence or lack business ideas.

\section{Improving national innovation policy and public $R \& D$}

21. The lack of planning, implementation and coordination in national innovation policy also holds back innovation. The current public research system is marked by ingrained, administrative dispersion, by rivalry among various stakeholders and a consequent overlapping of innovation efforts. There is also a lack of transparency of support at the inter-ministerial and inter-agency level. The system of business support services (business incubators, technology parks, platforms and centres, etc.) would need to be more in touch with business demands, tailored to specific phases of a firm's life cycle. The institutional dispersion at the planning stage has undermined the delivery of government support services for business R\&D and innovation activities. Frequent changes in policy measures and instruments have rendered the innovation framework unstable and unpredictable, making new policy initiatives less credible.

22. In pursuit of targets of innovation policies, Slovenia established an interdisciplinary research council that is in charge of evaluation and public budget allocation. This upgrades collaborative links between major stakeholders of innovation policy, which should be improved further. The Research and Innovation Strategy of Slovenia 2011-20 (RISS) and the National Higher Education Programme 2011-20 (NHEP) also propose measures for necessary reforms of the national innovation system and measureable implementation targets (OECD, 2014e). These aim towards a unifying innovation policy and should be implemented. An additional planned document within the EU framework is Smart Specialisation Strategy, with a goal to enable Slovenia to become a technology leader in its priority areas.

23. To enhance the efficiency of public R\&D and to meet demands of the business community a research voucher system was introduced to encourage companies to hire public research organisations to do research for them (OECD, 2013b). Additionally, to foster business R\&D and innovation Slovenia offers grants, R\&D tax incentives, loan guarantees, mezzanine capital and equity (Figure 18). Centres of excellence $(\mathrm{CoE})$, competence centres $(\mathrm{CCs})$ and development centres that stimulate collaboration of public research with the business sector were also established (OECD, 2012b, 2012c, 2014e). CoE are aimed at promoting the concentration of knowledge at priority technological areas and horizontal linking along the entire chain of knowledge development, based on strategic partnerships between the private sector and academia. The CCs are defined as development and research centres that are managed by partners from industrial sector and link partners from the industry and public research sector. They focus on the promotion of the development capability and the application of new technologies (Ministry of higher education, science and technology, 2014). Development centres are linking private sector, research institutions and local authorities with the aim to concentrate knowledge and infrastructure in the priority sectors or at the regional level. 
ECO/WKP(2015)59

Figure 18 Most relevant instruments of public funding of business R\&D, 2014

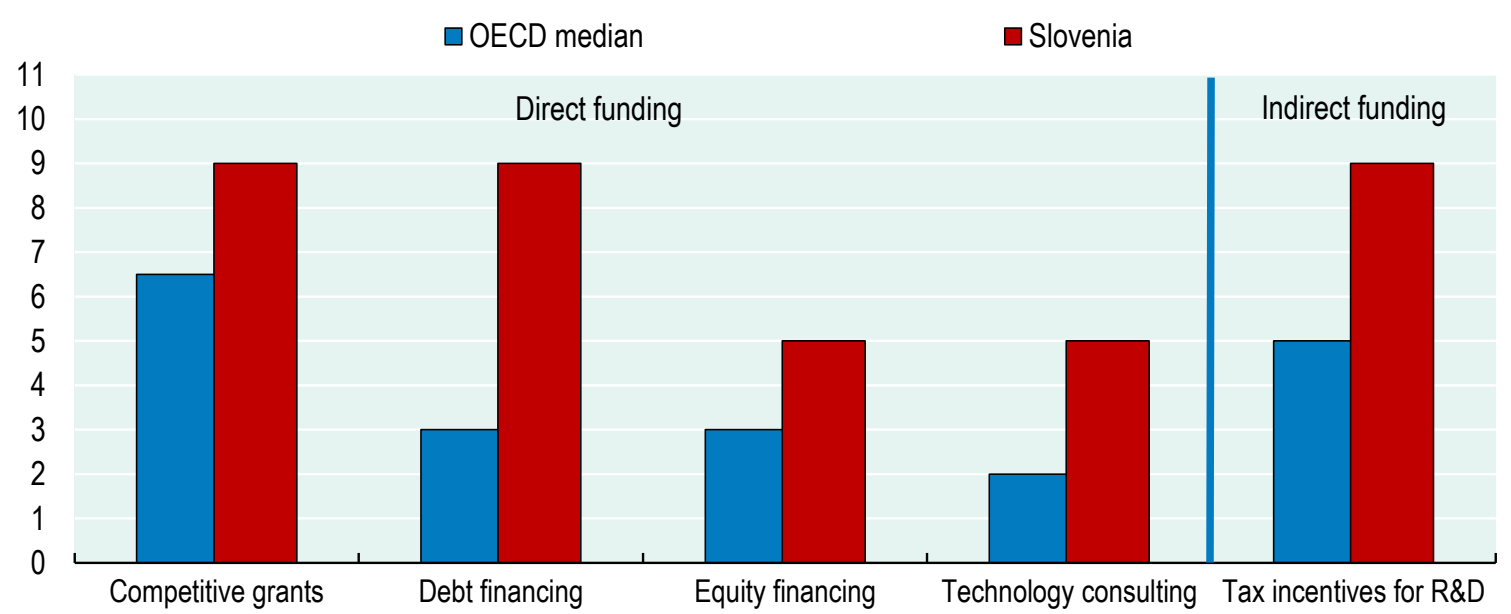

Note: The chart depicts the responses to questions on the principal instruments of public funding of business R\&D and innovation and how their relevance has changed. The answers run from 0 (not used) to 9 (high and increasing relevance).

Source: OECD, based on country responses to the OECD Science, Technology and Industry Outlook policy questionnaire 2014.

24. Slovenian government needs to reform universities and public research organisations (PROs) to facilitate further improvements in public research. Public research has delivered some impressive results in terms of scientific output (Figure 17), despite the low funding - Slovenia spends $0.3 \%$ of GDP on total higher education spending on R\&D (HERD), compared to the OECD average of $0.4 \%$ of GDP (OECD, 2013f, 2013g). To facilitate further improvements, the governance of public research should be reformed so that universities and PROs are given more autonomy, firmly tied to accountability and performance. Such autonomy requires a strong and clear governance model. Universities will require strong leadership and the possibility to build critical mass, with active international recruiting and modern career models. Funding of science should support change through appropriate incentives. For PROs, a similar reform agenda is needed, after agreeing on the main strategic objectives of each major institute (OECD, 2012c, 2014a).

25. Slovenia's R\&D system is highly internationalised in some respects (e.g. participation in European R\&D programmes), but much less so in others (e.g. attracting foreign researchers and students), limiting the talent pool. Slovenia's lack of attractiveness is due to the fact that a majority of subjects are taught in Slovenian language, opaque or overly restrictive selection procedures, unattractive career models and salary regulations. Several measures aim to make Slovenia more attractive internationally, such as university programmes in foreign languages, payment of European funds to foreign researchers and opening of research programmes to foreign participation (e.g. in the Young Researcher Programme) (OECD, 2012b, 2012c). The government should also encourage businesses, universities and PROs to upgrade their strategic capabilities and become more ambitious in the choice of their participation in international, especially EU programmes. To extend the limited talent pool, the academic labour market should be opened further and attract top researchers and students from all over the world (OECD, 2012c). 


\section{Recommendations on innovation and $R \& D$}

\section{Key recommendations}

- Implement the government's unified innovation policy and monitor its progress. Improve collaborative links between major stakeholders of innovation policy.

\section{Other recommendations}

- Strengthen entrepreneurship education in schools and reform the education system so that it encourages creativity and entrepreneurship drive.

- $\quad$ Facilitate reform in universities and public research organisations, enhancing their autonomy, leadership and accountability. Further promote international co-operation.

\section{Education, skills and human capital}

26. Education is an important determinant of long-term growth and productivity performance in OECD countries (Sala-i-Martin et al., 2004; Hanushek and Wößmann, 2008 and 2011, OECD, 2013d). Not only does the accumulation of human capital boost labour productivity, but cognitive skills improve individual earning potential, ability to deal with change and the distribution of income (OECD, 2013d).

27. Slovenia has slightly higher expenditure on pre-primary education per student than the OECD average, also due to low pupil-teacher ratio (OECD, 2014b). The Kindergarten Act 2008 and the Exercise of Rights to Public Funds Act 2012 made early childhood education more affordable, and enrolment rates are above OECD average (OECD, 2013e, 2015). Children above 3 years spend 35 hours per week in kindergarten, compared to less than 30 hours on average in EU (European Commission et al, 2014), which is an additional cost driver. This measure, however, supports female labour market participation. Nevertheless, efficiency of spending could be improved to rationalise higher costs. Child-teacher ratios - currently the ratio is one of the lowest among the OECD countries (OECD, 2014b) - should be allowed to rise, and excess capacity could be transferred to locations that face particularly strong demand (e.g. Ljubljana) (OECD, 2011a).

28. Slovenia also has high expenditure per student in primary education, partly due to low average class size (OECD, 2014b). This is a consequence of a deliberately balanced development across all regions. Individual small settlements have schools where only a few pupils are enrolled, but equally require an adequate number of teaching and support staff, raising costs (OECD, 2011a). As in the case of preprimary education, primary education likewise offers free optional extended primary school programme, organised as morning and after school care. There is room for efficiency gains in reorganising schools with low number of pupils in remote areas and reallocating funds to schools where classes are already big enough. Average class size can be increased as evidence shows that employing better qualified teachers, with good working conditions, is more important for student performance than the number of teachers (Sutherland and Price, 2007; Hattie, 2009; OECD, 2009b).

29. Judging by PISA, Slovenian 15-year-olds perform well compared to OECD average, but variation in performance between schools and programmes is large. Slovenian 15-year-olds in PISA 2012 were above OECD average in mathematics and science but below in reading. Performance has decreased in recent years, especially in reading (OECD, 2013c). Schools/programmes with students from a disadvantaged socio-economic background perform worse in PISA (Figure 19) and exhibit much worse disciplinary climate (Figure 20) (OECD 2007, 2010a, 2013c). This can be partly explained by the fact that in Slovenia, the primary sampling is based on study programmes rather than different schools, hence the between-school variation captures the difference between different tracks that can be organised within the 
same school. Nevertheless, Slovenia still shows higher differences than countries - Austria, Czech Republic, Italy and Turkey - that use similar sampling. To address the inequality issues, the government has introduced measures targeting students from a disadvantaged socio-economic background, by offering intensive teacher education and training and introducing initiatives that help students with learning difficulties (Ministry of education, science and sport, 2014; OECD, 2015). However, the measures should be better targeted at socio-economically disadvantaged schools/programmes.

30. Students' interest in upper-secondary vocational education and training (VET) was on a decreasing trend, but there have been improvements in most recent years. The relatively long lasted decrease has created supply shortages in low-skilled manual jobs (OECD, 2014a). To sustain recent progress, additional effort should be put in fostering interest in VET programmes, highlighting good job prospects of such educational choice. Introduction of scholarships to further foster the interest in VET programmes in the school year 2015/16 is the move in the right direction. In international comparison the involvement of stakeholders in the Slovenian VET system remains limited, although there has been some progress following the reform of vocational education (2008-11). Practical training in the work place increased, and $20 \%$ of the curriculum is now designed in co-operation with social partners, particularly local companies (OECD, 2014a and 2015). A major challenge is to reform the VET system in a way that equips people with the skills needed by the fast-changing labour market and helps students to develop both foundation skills and acquire more technical capabilities (OECD, 2010b).

Figure 19 Slovenia has one of the highest variations in mathematics performance between schools

Percentage of explained variance by PISA index of economic, social and cultural status of students and schools

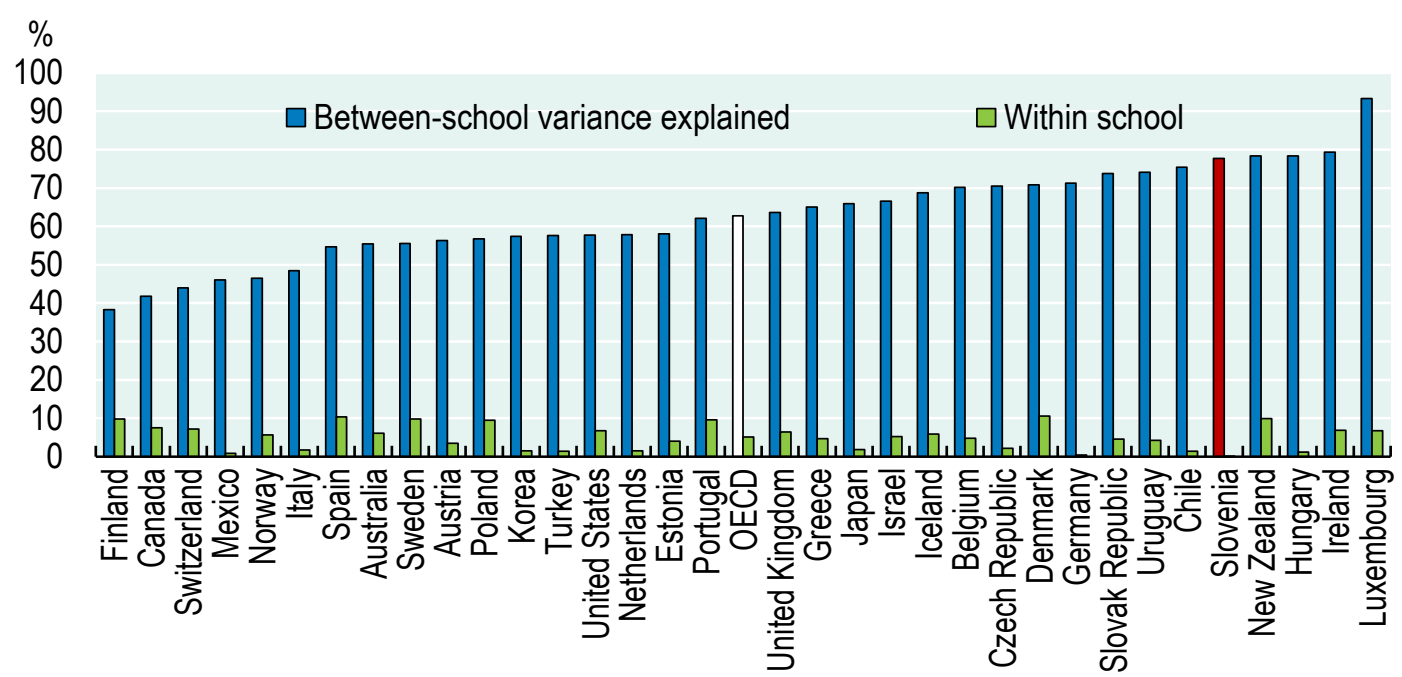

Note: In Slovenia, the primary sampling unit is defined as a group of students who follow the same study programme within a school (an educational track within a school). So in the case when various programmes are organised within the same school, the betweenschool variation captures the difference between tracks within a school. Similar sampling based on programmes is also done in Austria, Czech Republic, Italy and Turkey. The statistical data for Israel are supplied by and under the responsibility of the relevant Israeli authorities. The use of such data by the OECD is without prejudice to the status of the Golan Heights, East Jerusalem and Israeli settlements in the West Bank under the terms of international law.

Source: OECD, PISA 2012 Database. 
Figure 20 Difference in disciplinary climate between advantaged and disadvantaged schools is the highest in Slovenia

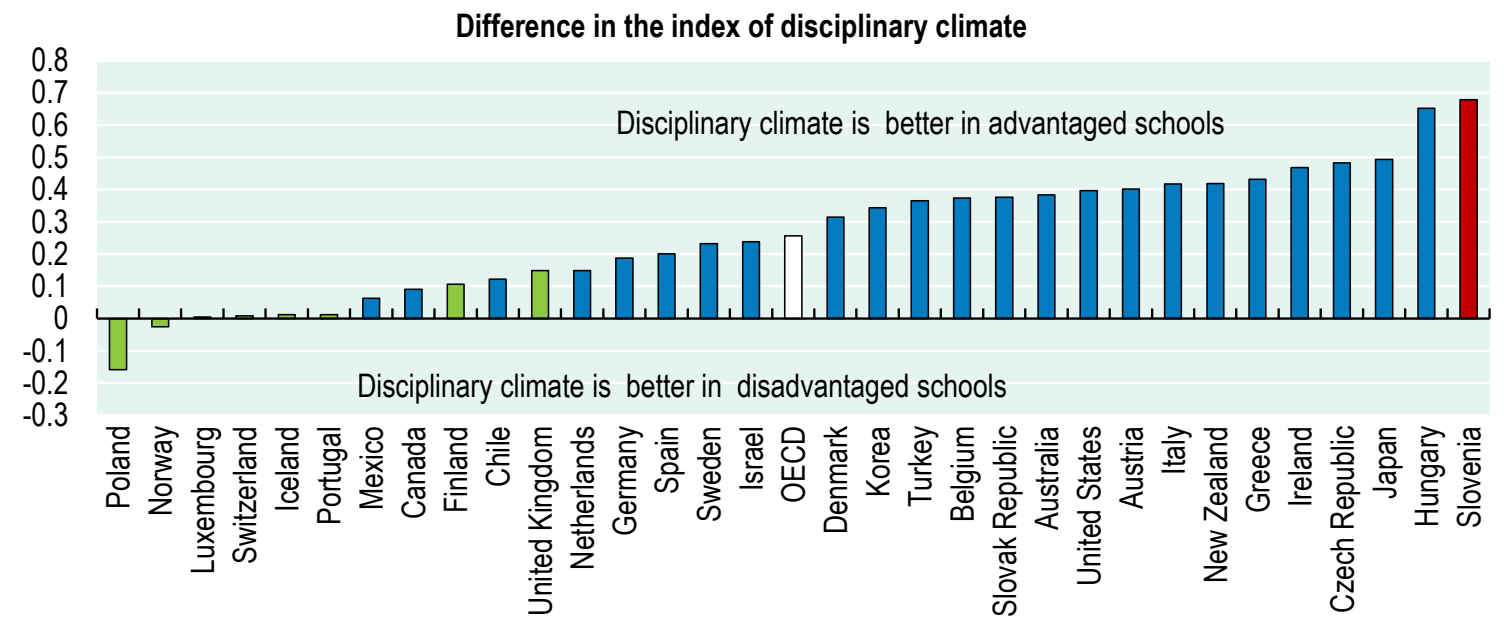

\begin{abstract}
Note: In Slovenia, the primary sampling unit is defined as a group of students who follow the same study programme within a school (an educational track within a school). So in the case when various programmes are organised within the same school, the betweenschool variation captures the difference between tracks within a school. Similar sampling based on programmes is also done in Austria, Czech Republic, Italy and Turkey. The statistical data for Israel are supplied by and under the responsibility of the relevant Israeli authorities. The use of such data by the OECD is without prejudice to the status of the Golan Heights, East Jerusalem and Israeli settlements in the West Bank under the terms of international law.
\end{abstract}

Differences in the index of disciplinary climate between students in disadvantaged and advantaged schools that are not statistically significant are marked in green.

Countries and economies are ranked in ascending order of the difference between disadvantaged and advantaged schools.

Source: OECD, PISA 2012 Database.

31. Participation in adult education programmes is relatively high, but is concentrated in the besteducated and prime-age workers (OECD, 2014a). Adults with low educational attainment show considerably less interest in adult learning activities and difference between individuals with high and low educational attainment in adult education participation is the highest in the EU (IMAD, 2010). Measures should be taken to bridge the gap by making adult education more affordable, boost participation in lifelong learning and reduce differences in participation between individuals with low and high education. To improve accessibility of adult education, targeted subsidies could be introduced to reduce adult education costs for those with low educational attainment (OECD, 2011a). Additionally, adult education should provide skills that are demanded by employers, raising also productivity (OECD, 2014a).

32. There is scope to increase tertiary education attainment of students whose parents have low education. In 2012 Slovenia had one of the highest entry rates to universities, but the proportion of students whose parents have low education levels was one of the lowest among the OECD countries (Figure 21). Despite generous public support for tertiary education and one of the lowest direct private costs of studying (Figure 22), public support is regressive and not well targeted to the weakest. 35\% of tertiary education expenditure goes to the top quintile of the income distribution and only $9 \%$ to the lowest one (OECD, 2013b). The government has offered scholarships to disadvantaged students to attend tertiary education (Eurydice, 2011). It could introduce better means testing of education-related allowances (transportation, student meals in tertiary education) and institute stricter eligibility criteria (accommodation subsidies, state scholarships). Important progress in means testing of benefits has been made with the implementation of a comprehensive electronic system in 2012 , however, the eligibility criteria could be tightened further with carefully defined new thresholds (OECD, 2013b). 


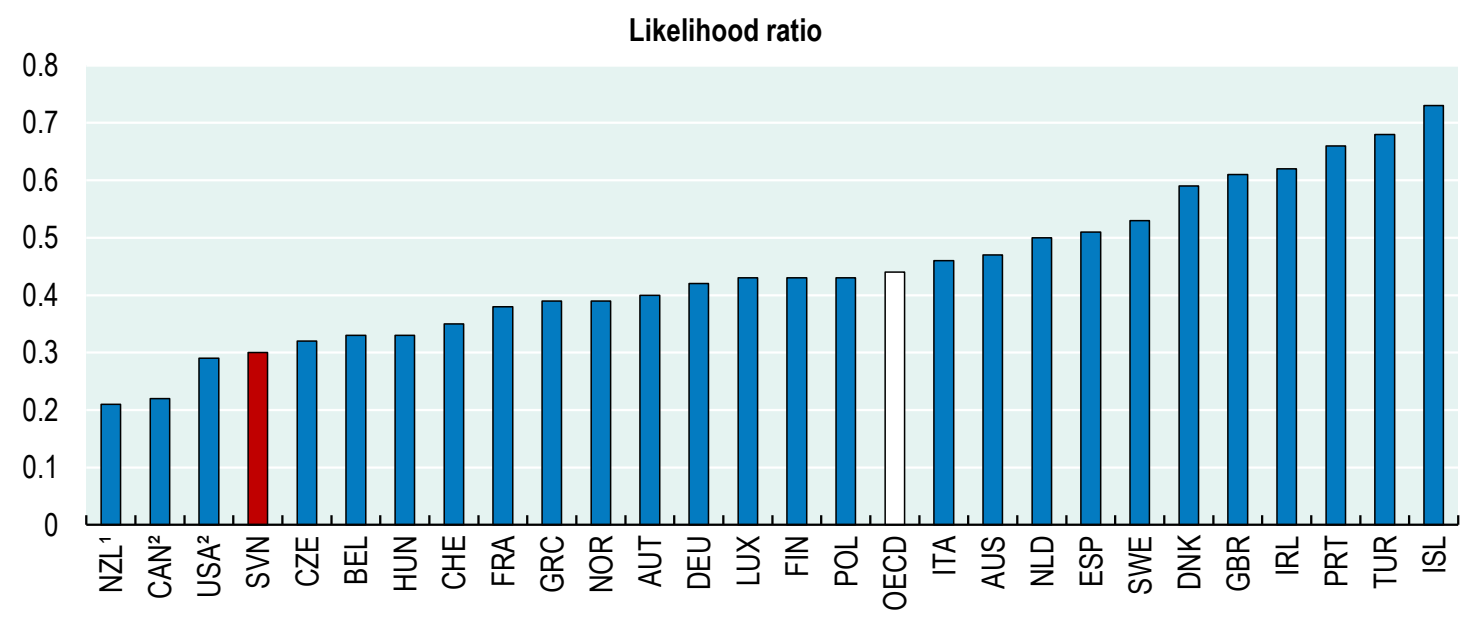

Note: The number of students attending higher education are under-reported for Australia, Canada, New Zealand and the United States compared to the other countries as they include only students who attained ISCED 5A, while the other countries include students who attained ISCED $5 \mathrm{~A}$ and/or 5B. This may understate intergenerational mobility in these countries.

1. Data from Adult Literacy and Lifeskills Survey (ALL) of 2006.

2. Data from Adult Literacy and Lifeskills Survey (ALL) of 2003.

Source: OECD Education at a Glance 2012; table A6.1.

33. The tertiary system does not produce workers with the skills in demand. Mismatches between the output of the tertiary level education system and the need of the labour market are on the rise (Figure 23). Farčnik and Domadenik (2009) find that graduates in health, computing, engineering, manufacturing and construction have the highest likelihood of getting employed in the six months following their graduation. Despite recent improvements the share of science and engineering graduates in Slovenia is low in international comparison (SORS, 2012), while the share of those in humanities and social sciences is high, contributing to the high unemployment among youth (IMAD, 2014b; OECD, 2011a). A greater share of engineering and science graduates is associated not only with a greater innovative and technology absorption capacity of the economy but also with human capital spill-overs and economy-wide productivity gains (OECD, 2011a). Furthermore, the proportion of dissatisfied employers with generic skills of tertiary graduates was the $2^{\text {nd }}$ highest (18\% compared to EU average of $8 \%$ ) among the EU countries (European Commission, 2010), which may have contributed to higher mismatch. It is therefore important to boost the number of quality graduates from technical fields by improving demand via highlighting good job prospects of these professions and by providing sufficient institutional capacity via allocation of appropriate resources to these programmes. Entry rates in fields with poor labour market prospects should be reduced (IMAD, 2014b). 
Figure 22 Private costs of attaining tertiary education, 2010
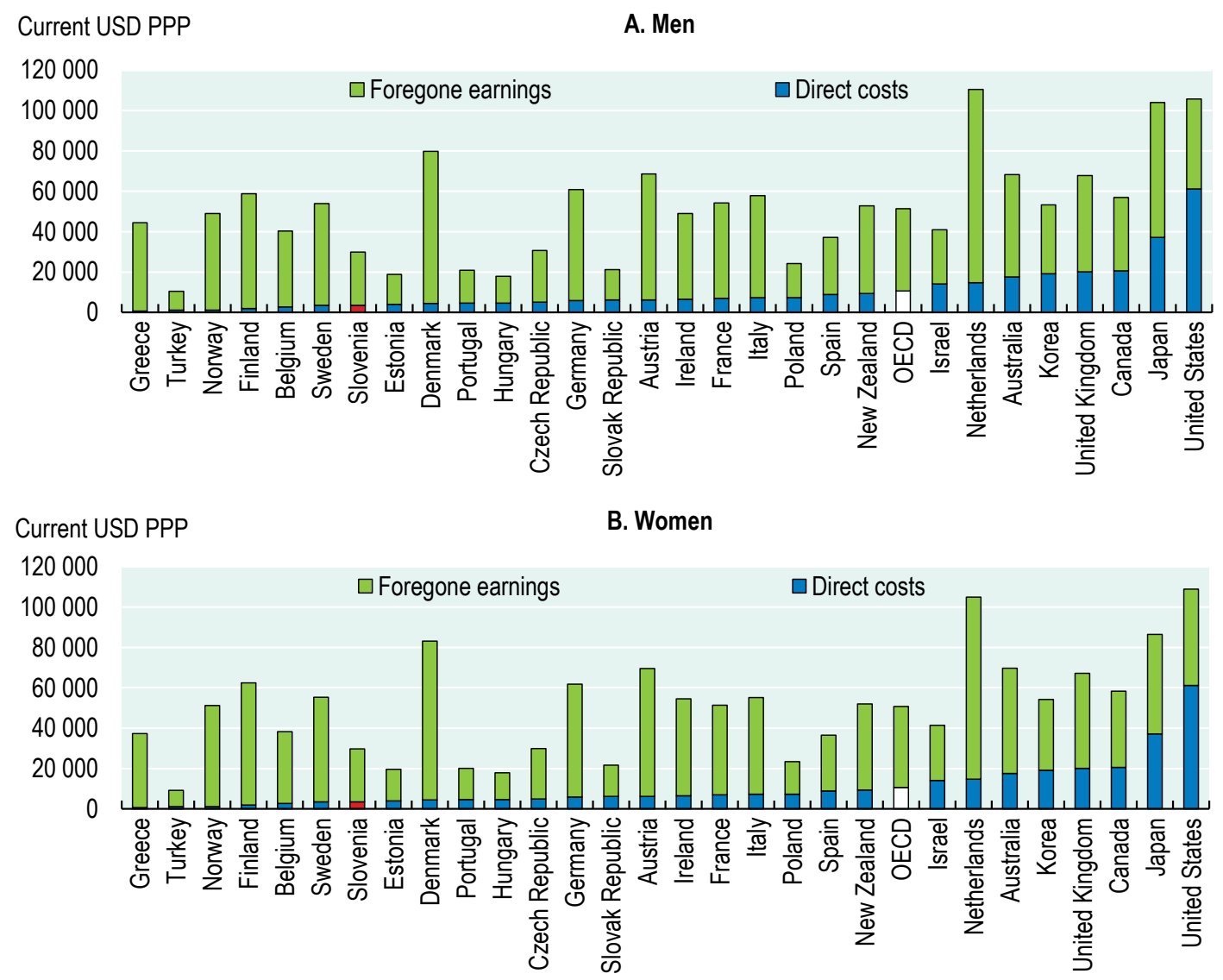

Note: Values are based on the difference between individuals who attained a tertiary education compared with those that attained an upper secondary or post-secondary non-tertiary education.

Source: OECD (2014b), Education at a Glance 2014: OECD Indicators.

Figure 23 Mismatches on the labour market have increased for highly educated people

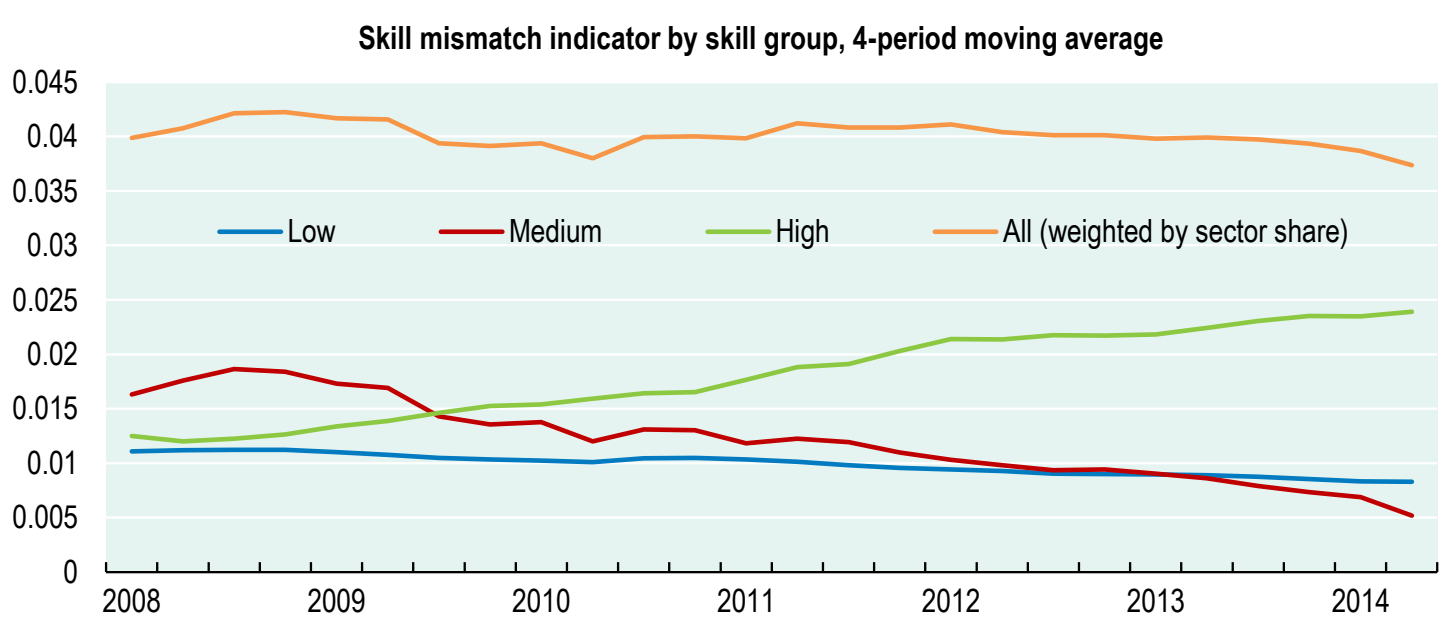

Note: The skill mismatch indicator is defined as the average absolute deviation between the share of education groups in employment and their share in the working age population. For details on the estimation of the skill mismatch indicator see European Commission. 2013. Labour Market Developments in Europe 2013: Brussels.

Source: Eurostat, calculations by IMAD. 
34. Per-student expenditure on core services at the tertiary level in Slovenia is low (OECD, 2014b; Figure 24), but it could be used more efficiently. Funding should be more dependent on students' progress and graduation rates by raising variable part of financing, which currently only amounts to $3 \%$ of total funding (OECD, 2013b). Faculties are also constrained by the Public Sector Act in determining salaries, which are lower than in the private sector, making it harder to compete for hiring and retaining most talented staff (OECD, 2011a). As should be the way forward in other parts of the public sector, individual faculties could be given more freedom in determining salaries, including performance related pay, which would also increase the quality of instruction and research output.

Figure 24 Annual expenditure per student by educational institutions for all services by level of education, 2011
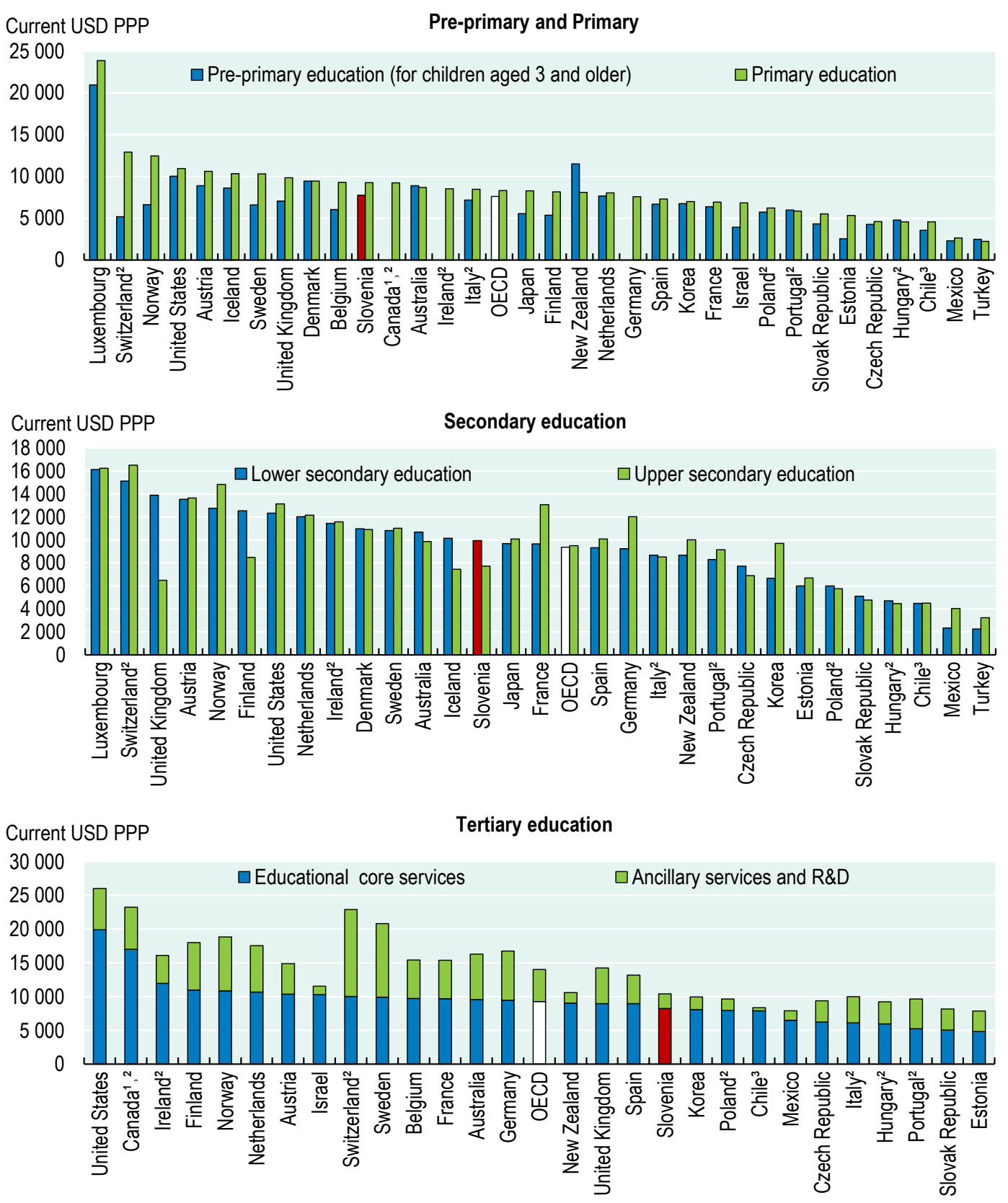

1. Year of reference 2010.

2. Public institutions only (for Canada, in tertiary education only; for Italy, except in tertiary education).

3. Year of reference 2012.

Source: OECD (2014a), Education at a Glance 2014: OECD Indicators. 
35. Efficiency of tertiary education system could be further increased by limiting tuition fee waivers and other in-study benefits to a normal study length. Currently, students have many benefits, including state-funded tuition fee waivers for over $80 \%$ of students (Eurydice, 2011), subsidies for living expenses (meals, accommodation, transportation and cultural activities), state scholarships and the flexibility of student work. The in-study benefits that are not tied to progress of studies and the shortage of workplaces for youth attract "fake students", who would not normally go into tertiary education. They are estimated to be as high as one third of tertiary students (Šušteršič et al., 2010). Such system does not provide incentives for the rapid completion of studies (OECD, 2011a; Čelebič, 2014). There is potential for improvement by tightening the eligibility of generous subsidies and in-study benefits to normal study length (OECD, 2011a). Finland, for example, has recently shortened the period during which students are eligible to receive financial support (OECD, 2014d). The new law on higher education is being prepared, according to which students who do not progress regularly, have to pay tuition fees. Its adoption is highly encouraged.

\section{Recommendations on education and training}

- Raise pupil-teacher ratios in pre-primary education and increase class size in primary education to reduce costs. Reorganise schools that serve too few students.

- Better target measures to upper secondary socio-economically disadvantaged schools and programmes.

- Improve the accessibility of adult education for individuals with low educational attainment levels introducing targeted subsidies. Evaluate how the outcome from adult education programmes is used by employers.

- Better target students from disadvantaged backgrounds to attain tertiary education. Further strengthen means testing of education-related benefits.

- Improve incentives to boost further the number of tertiary graduates from the fields of mathematics, science and technology by highlighting good job prospects and by providing funding for sufficient institutional capacity. Reduce entry rates in fields with poor labour market prospects.

- Give faculties more freedom in determining their salaries.

- Tie tuition fee waivers and other in-study benefits to adequate progress in studies.

\section{Labour market policies for more jobs}

36. The unemployment rate rose by 6 percentage points since the start of the crisis to approach $11 \%$ in the beginning of 2013, but has since decreased amid improving economic environment. More than 50\% of the unemployed have been out of work for one year or more (Figure 25, panel A), a 10 percentage point increase from 2007. Youth unemployment is also high and doubled from 2007 to over $20 \%$ in the first half of 2014 (Figure 25, panel B). In addition, youth participation rate has decreased by almost 10 percentage points from 2007, to $34 \%$ in 2013.

37. High incidence of long-term unemployment is partly caused by institutional factors. The combined generosity of unemployment benefits, social assistance and other transfers, together with taxes, act as disincentives for the unemployed or the inactive to return to work (OECD, 2013b), Table 3. For instance, a principal earner of a one-earner married couple with two children (at $67 \%$ of average wage) has one of the highest average effective tax rates (AETR). He loses $81 \%$ of the increase in gross income due to taxes and reduced benefits when moving from inactivity to employment. The average effective tax rates in Slovenia are significantly above $50 \%$ for all but two-earner married couples, and above the OECD average in all groups. Reform could boost work incentives if, at low income levels, benefits would be withdrawn at a lower rate than the after-tax increase in earnings, to allow a more generous net increase in income. 
Figure 25 Long-term unemployment is high and youth unemployment has risen

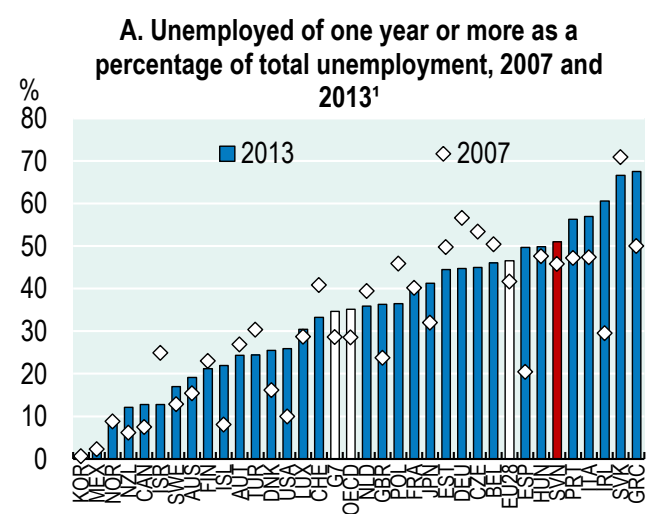

B. Youth unemployment rate

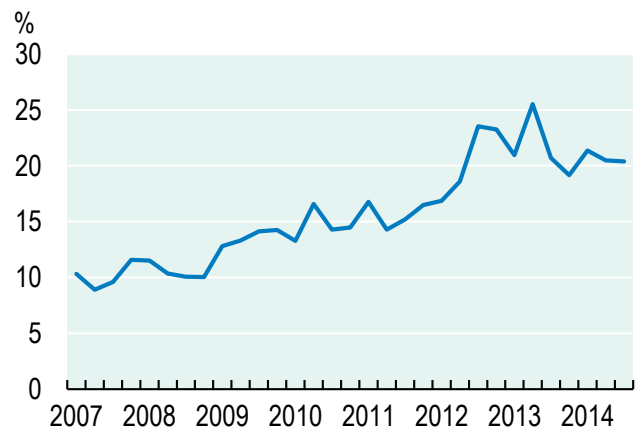

1. Countries are shown in ascending order of the incidence of long-term unemployment in 2013. Data are not seasonally adjusted but smoothed using three-quarter moving averages. OECD is the weighted average of 33 OECD countries excluding Chile.

2.

Data are seasonally adjusted and refer to the unemployment rate of individuals aged 15-24.

Source: OECD calculations based on quarterly national labour force surveys, for Panel A; and OECD Short-Term Labour Market Statistics database, for Panel B.

38. At the same time, in 2014 only $22 \%$ of registered unemployed received unemployment benefits, and almost 50\% have not received any income in 2014 (Institut RS za socialno varstvo, 2014). To insure workers against labour market risks higher number of the unemployed should be covered and the duration of benefits could be increased. Currently, unemployment benefits are a strongly increasing function of previous work experience, with up to 25 months of insurance provided for older workers, but only two months for younger workers. Longer benefits should be targeted to vulnerable groups such as the young and the low-skilled (Chetty, 2008).

39. The government has tried to address the issue of high youth unemployment by several measures. Employers are partly exempt of paying income taxes and employers' contributions for employing youth permanently. Furthermore, within the framework of active labour market policies (ALMPs) co-financing of corporate scholarships, employment subsidies, the education and training and the programme promoting self-employment have been offered (Bank of Slovenia, 2013). At the European level, the Youth Guarantee programme aims at facilitating the transition of youth from education to employment. All these programmes should be closely monitored and evaluated from the perspective of effectiveness (IMAD, 2014b). IMAD (2014b) estimates that the percentage of youth (in the 15-29 age group) that left unemployment due to ALMP was around 14\% in 2013. These programmes have, together with improved economic situation, led to stabilisation of youth unemployment but it remains high (Figure 25, panel B). 
Table 3 Inactivity traps and unemployment traps are high in international comparison

Average effective tax rate when moving from unemployment/inactivity into work, per cent, 2012

\begin{tabular}{|c|c|c|c|c|c|c|c|}
\hline & \multirow{2}{*}{$\begin{array}{l}\text { Wage level } \\
\text { (\% of } \\
\text { average } \\
\text { worker) }\end{array}$} & \multicolumn{3}{|c|}{ Inactivity trap ${ }^{1}$} & \multicolumn{3}{|c|}{ Unemployment trap² } \\
\hline & & Slovenia & $\begin{array}{l}\text { other } \\
\text { CEEC }\end{array}$ & $\begin{array}{l}\text { OECD } \\
\text { average }\end{array}$ & Slovenia & $\begin{array}{l}\text { other } \\
\text { CEE } \\
\text { C }\end{array}$ & $\begin{array}{l}\text { OECD } \\
\text { average }\end{array}$ \\
\hline \multirow{3}{*}{$\begin{array}{l}\text { One-earner married } \\
\text { couple }\end{array}$} & 67 & 65 & 55 & 63 & 88 & 62 & 70 \\
\hline & 100 & 63 & 46 & 54 & 76 & 57 & 65 \\
\hline & 150 & 56 & 43 & 48 & 65 & 51 & 59 \\
\hline \multirow{3}{*}{$\begin{array}{l}\text { Lone parent with two } \\
\text { children }\end{array}$} & 67 & 71 & 43 & 56 & 84 & 66 & 69 \\
\hline & 100 & 63 & 48 & 55 & 78 & 68 & 68 \\
\hline & 150 & 64 & 44 & 51 & 69 & 58 & 62 \\
\hline \multirow{3}{*}{$\begin{array}{l}\text { One-earner married } \\
\text { couple with two } \\
\text { children }\end{array}$} & 67 & 81 & 57 & 66 & 88 & 59 & 69 \\
\hline & 100 & 64 & 50 & 60 & 75 & 55 & 67 \\
\hline & 150 & 65 & 46 & 54 & 66 & 50 & 61 \\
\hline \multirow{3}{*}{$\begin{array}{l}\text { Two-earner married } \\
\text { couple with two } \\
\text { children }\end{array}$} & 67 & 45 & 35 & 35 & 93 & 68 & 70 \\
\hline & 100 & 49 & 34 & 36 & 80 & 63 & 66 \\
\hline & 150 & 48 & 33 & 37 & 68 & 55 & 60 \\
\hline
\end{tabular}

Note: Participation tax rates measure the extent to which taxes and benefits reduce the financial gain of moving into work.

1. Average effective tax rate when moving from inactivity into work for selected family types and earnings levels. The estimates here relate to the situation of a person who is not entitled to unemployment benefits (e.g. because they entitlements have expired). Instead, social assistance and other means-tested benefits are assumed to be available subject to relevant income conditions.

2. Average effective tax rate for a transition into full-time work for persons receiving unemployment benefits at the initial level, for selected family types and earnings levels (same in new job as in previous).

Source: OECD, Tax-Benefit Models.

40. Employment prospects of low-skilled workers are affected also by the relatively high minimum wage. Slovenia has one of the highest minimum wages relative to median among the OECD countries (Figure 26), and it was raised by $23 \%$ in 2010 . According to the Bank of Slovenia (2014a) survey, the minimum wage hike was the main reason for dismissals in $7 \%$ of firms (Figure 27), and prevented new hiring in close to a quarter of firms, making it a major barrier to employment. High minimum wage also exerts pressure on other wages and prices - over a fifth of the firms had to raise wages for all workers and around 13\% of the firms raised prices (Bank of Slovenia, 2014a). The Law on Minimum Wage stipulates that minimum wage should be increased by at least the inflation rate each year, but cites other benchmarks for adjustment, such as wage trends, economic growth and employment trends. Evidence shows that earned income tax credits, rather than minimum wage increases, have been successful in supporting the incomes and employment of lower-income families in the USA (Eissa and Hoynes, 2006; Clemens and Wither, 2014). Going forward, minimum wage growth should be moderated, with a view to restoring the link to productivity and boosting employment opportunities. Incomes of low-skilled workers can be better protected through social transfers and tax measures that incentivise employment. 
Figure 26 Slovenia is one of the countries with the highest minimum wage relative to the median wage, 2012

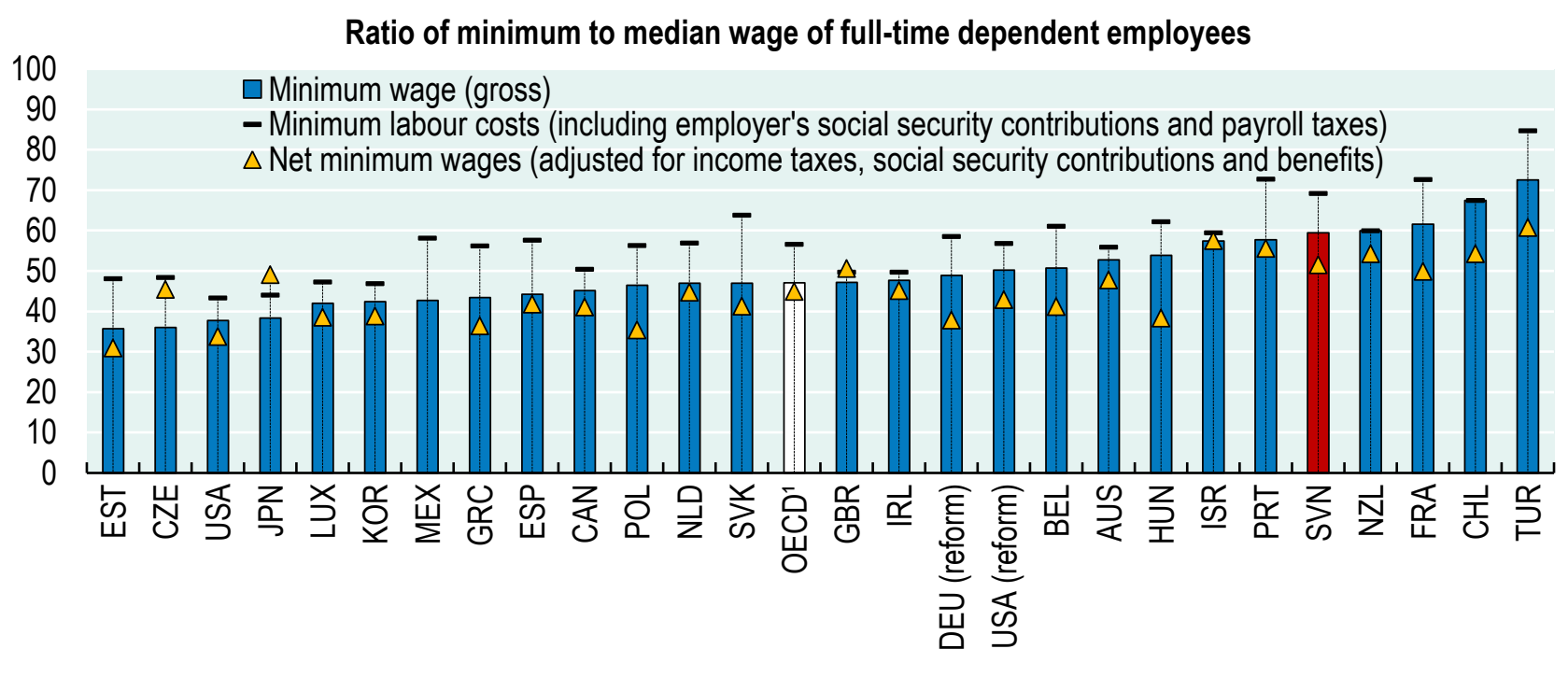

1. Median ratio for the countries shown.

Source: OECD Minimum Wage database; and OECD Tax-Benefit Models.

Figure 27 How did the firms react to change in minimum wage legislation

\begin{abstract}
$\%$ of respondents
\end{abstract}
70

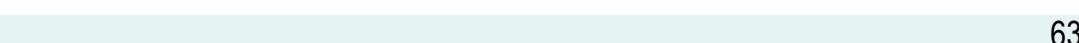

60

50

40

30

20

22

10

0

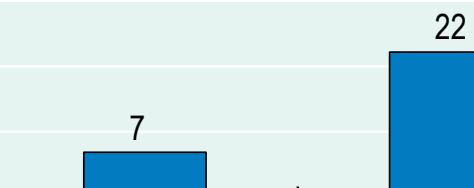

13

Lay off people Less people were hired Increase prices

Reduce other costs Increase wages above the minimum wage

Note: Only answers of companies with minimum wage receivers are included.

Source: Wage Dynamics Network Survey 2014, Bank of Slovenia calculations. 
41. Before the 2013 labour reform, Slovenia had one of the most restrictive employment protection (EPL) for permanent contracts and no direct cost for terminating fixed-term contracts (Figure 28) (OECD, 2014a). The aim of the reform was to increase labour market flexibility and decrease labour market duality. The reform increased flexibility (e.g. simplified administrative procedures related to hiring and firing and shorter notice periods) and lowered costs of permanent employment contracts (reduced severance payments). On the other hand, for fixed-term contracts, it introduced redundancy payments and limited to two years the maximum duration of a fixed-term employment for a given job (OECD, 2013b). In the case of dismissal, employers' costs are now the same across both contract types. Bank of Slovenia (2014a) survey shows that only 14\% of companies reported a change in their human resources policy due to the new legislation, (Figure 29, panel A). Evidence nevertheless confirms that the reform may have led to a slight reduction in duality as the share of permanent contracts among new hires indeed increased to $28 \%$ from $24 \%$ within a year (IMAD, 2014b; Figure 29, panel B). The increase was especially pronounced among youth (IMAD, 2014b).

\section{Figure 28 The employment protection legislation index in Slovenia prior to and following the change in the} year 2013

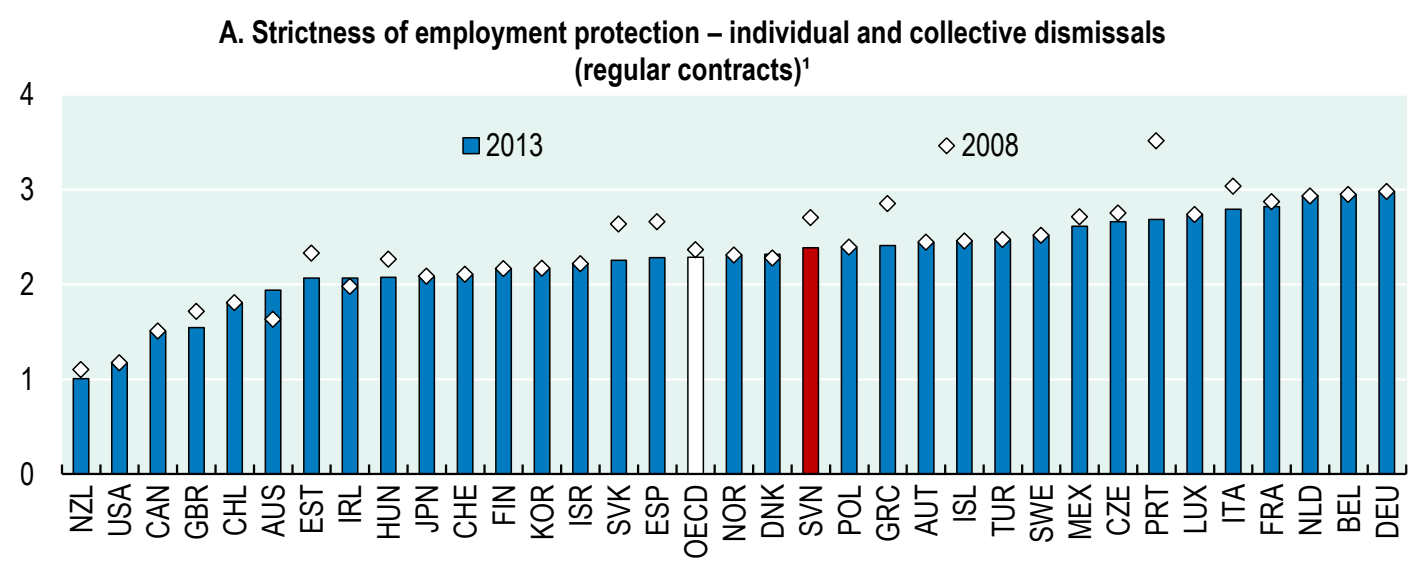

B. Strictness of employment protection - regulation on temporary contracts ${ }^{2}$

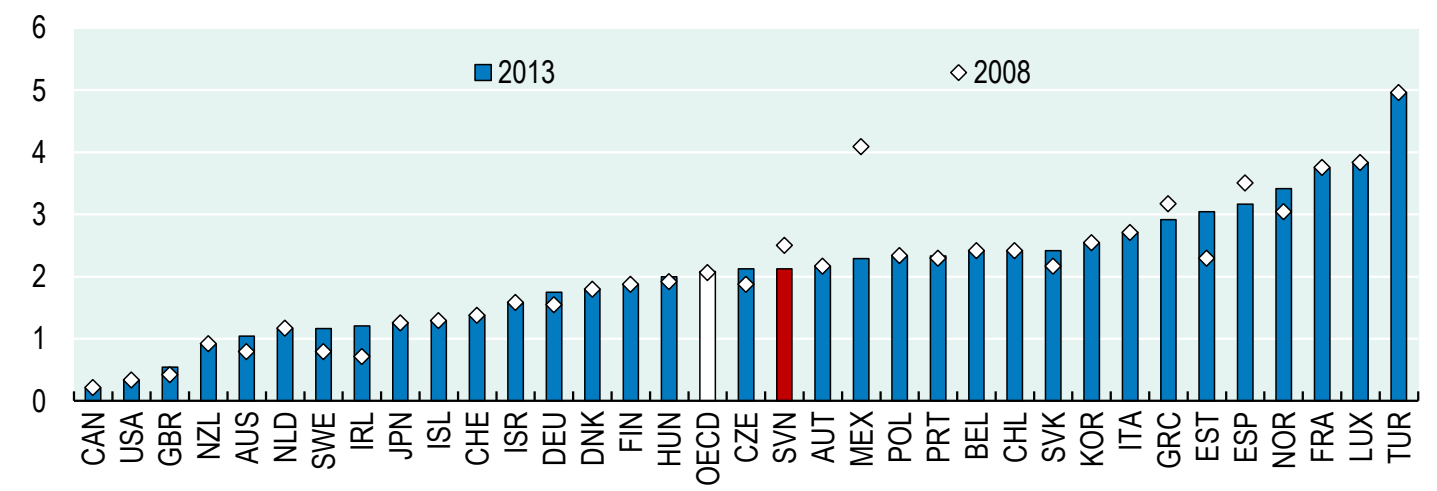

1. The OECD indicator of employment protection legislation (EPL) for regular employment measures the procedures and costs involved in dismissing individual regular employees. The indicator runs from 0 to 6 , representing the least to most restrictive EPL.

2. The OECD indicator of regulation on temporary contract (EPT) measures the restrictions on the use of temporary employment by firms, with respect to the type of work for which these contracts are allowed and their duration.

Source: OECD Employment Protection Database, 2013 update. 
Figure 29 The effects of the 2013 labour market reform on firms' employment decisions has been limited
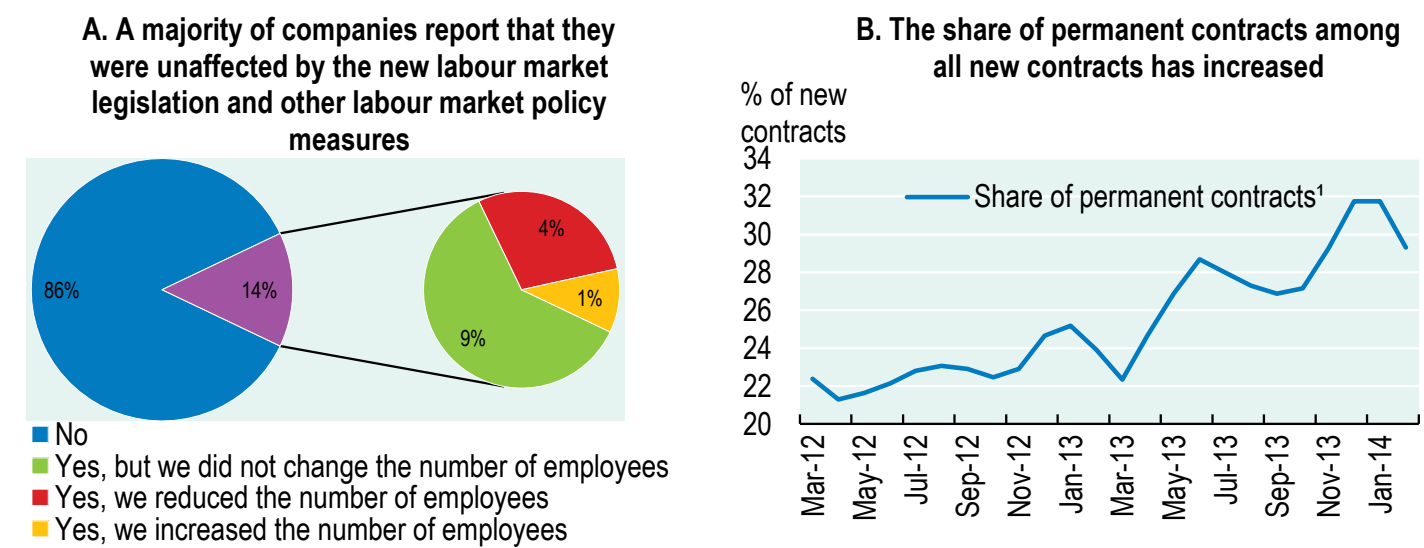

1.

Data are smoothed using a moving average filter.

Source: for Panel A: Wage Dynamics Network Survey 2014 and Bank of Slovenia calculation; for Panel B: SORS.

42. Student work was a major factor behind labour market duality, as it benefited from a preferential tax and regulatory treatment. Among youth, $74 \%$ of contracts are temporary, almost three times the OECD average (OECD, 2014a), and students account for the majority of those (IMAD, 2014b). For comparison, the incidence of temporary contracts among the total population is only marginally higher in Slovenia than the OECD average (17.5\% compared to $13.5 \%$ in 2012). The reform of student work from February 2015 introduced a minimum hourly gross wage rate and healthcare and pension contributions. Students will now accumulate years of pensionable service from their work. These changes increase the cost of student labour, but it will remain more flexible than regular employment. Phasing out the preferential treatment of student work has been often recommended to Slovenia by the OECD and is a major step in the right direction.

43. In 2012, Slovenia spent only $0.3 \%$ of GDP on active labour market programmes (ALMP), half the OECD average (Figure 30; OECD, 2014a). Slovenia spends little on training, especially of older and low-skilled people. Given the high share of long-term unemployed and the at-risk-of-poverty rate among the unemployed it would be sensible to step up ALMPs. Resources devoted to training and job search services should be increased to support employment and ensure that the long-term unemployed remain attached to the labour market (OECD, 2014a; IMAD, 2014b). Additionally, further development of active labour market programmes targeting the long-term unemployed to find jobs or access training would be beneficial (OECD, 2014a). Job counselling and activation programmes (e.g. interviews with employment counsellors, independent search for job, applications for jobs, acceptance of suitable work (OECD, 2005) are available to all unemployed, but, in practice, only less than 50\% take part. Encouraging participation through increased awareness, and specifically targeting the least involved groups of unemployed should become a policy priority. It is also necessary to create a system of independent evaluations of the effects of individual ALMPs and act accordingly if changes to the implementation measures are warranted (IMAD, 2014b). 
Figure 30 Slovenia spends less on active labour market programmes than majority of other countries

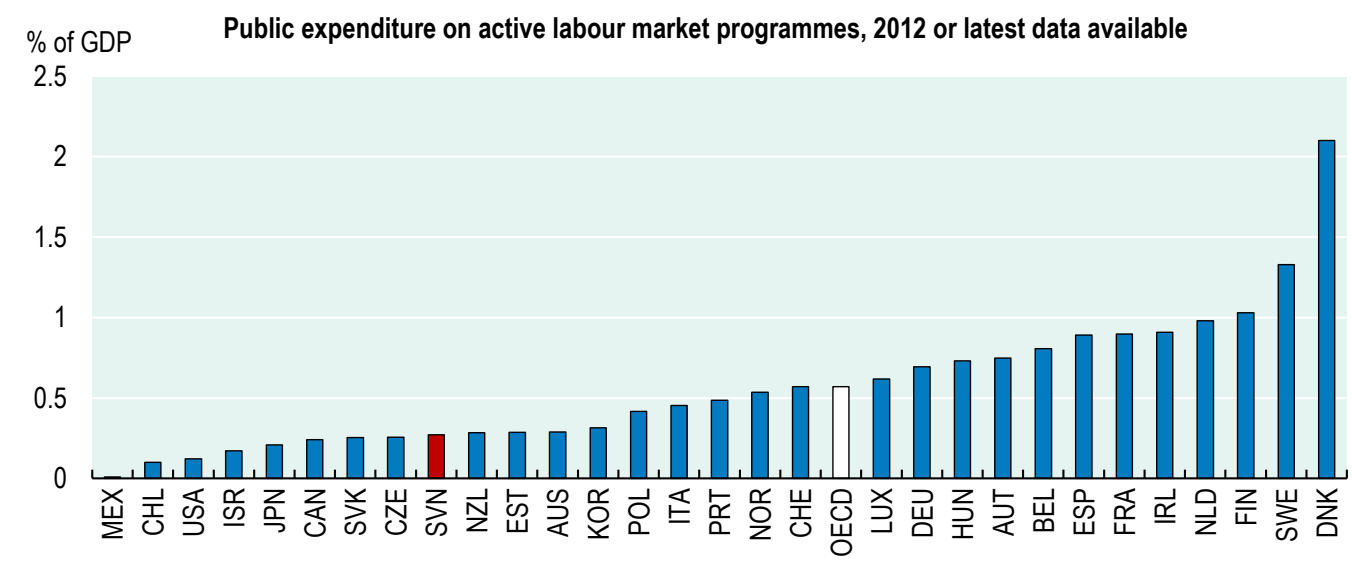

Source: OECD Social Expenditure database.

\section{Recommendations on the labour market}

\section{Key recommendations}

- Increase resources for active labour market policies and better target assistance to the long-term unemployed and the low-skilled, based on evaluation of individual programmes.

\section{Other recommendations}

- Restructure the combined effects of unemployment benefits, social assistance and taxes so that, at low income levels, benefits would be withdrawn at a lower rate than the after-tax increase in earnings, in order to increase work incentives for the unemployed and inactive persons.

- Increase coverage rates for unemployment benefits, making them less reliant on previous work experience.

- Moderate growth in the minimum wage, with a view to restoring the link to productivity and gradually increasing the gap between the minimum and median wage.

\section{Lowering barriers to product market competition and improving the business environment}

\section{Regulatory settings should promote rather than inhibit competition}

44. Slovenia's overall regulatory framework is among the most restrictive in the OECD as indicated by the OECD product market regulation (PMR) indicator (Figure 31, panel A). The PMR score has improved since 2008, but is worse than for most of its Central and Eastern European country (CEEC) peers and other euro area countries. This underperformance stems largely from the pervasive state involvement in the economy, but there is room for further improvement also with the complexity of regulatory procedures and administrative burdens on start-ups (Figure 31, panel B).

45. Product market regulation is essential for well-functioning market economies to protect market integrity, and to achieve environmental, health and safety objectives. Yet, regulations can also create unnecessary barriers to market entry, limit the ability of firms within a market to compete, or reduce the choices and information available to consumers. Many empirical studies have shown that competition can raise output per capita by increasing investment and employment as well as by encouraging companies to 
be more innovative and efficient (e.g. Bouis and Duval, 2011; Bourlès et al. 2010; Conway et al., 2006; Nicoletti and Scarpetta, 2005). Dall'Orso and Sila also show that a less restrictive business environment has a positive effect on productivity (see also Annex 3). In light of these economic gains, many countries have, step by step, removed obsolete or badly-designed regulations over the past decades. They have reduced state involvement in business sectors, made it easier for entrepreneurs to create firms and to expand them, and facilitated the entry of foreign products and firms.

\section{Figure 31 Product market regulation is overly strict}

\section{A. Overall PMR indicator}

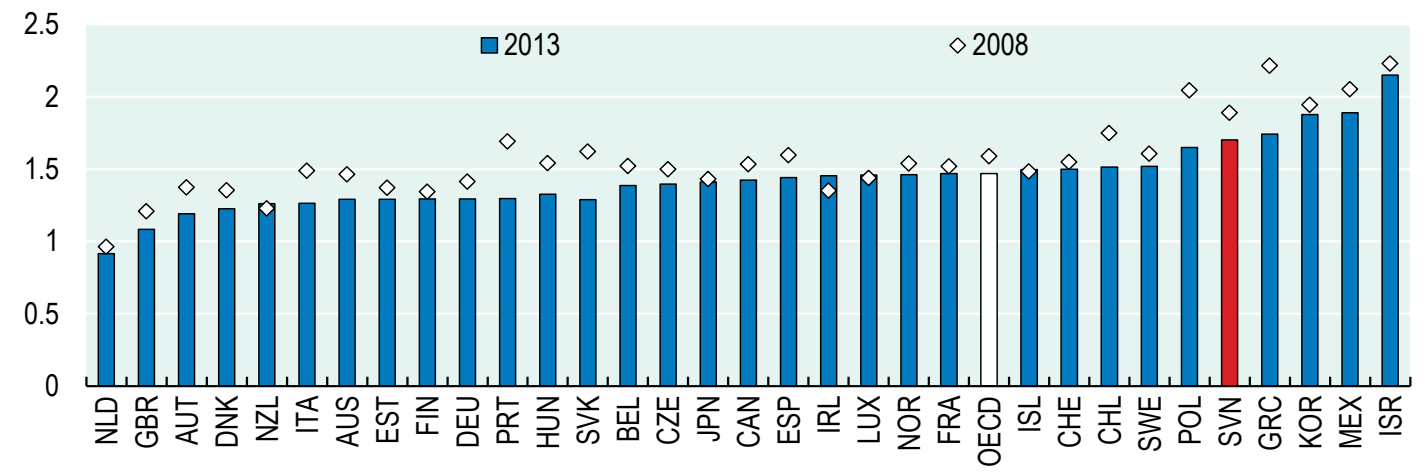

B. PMR components
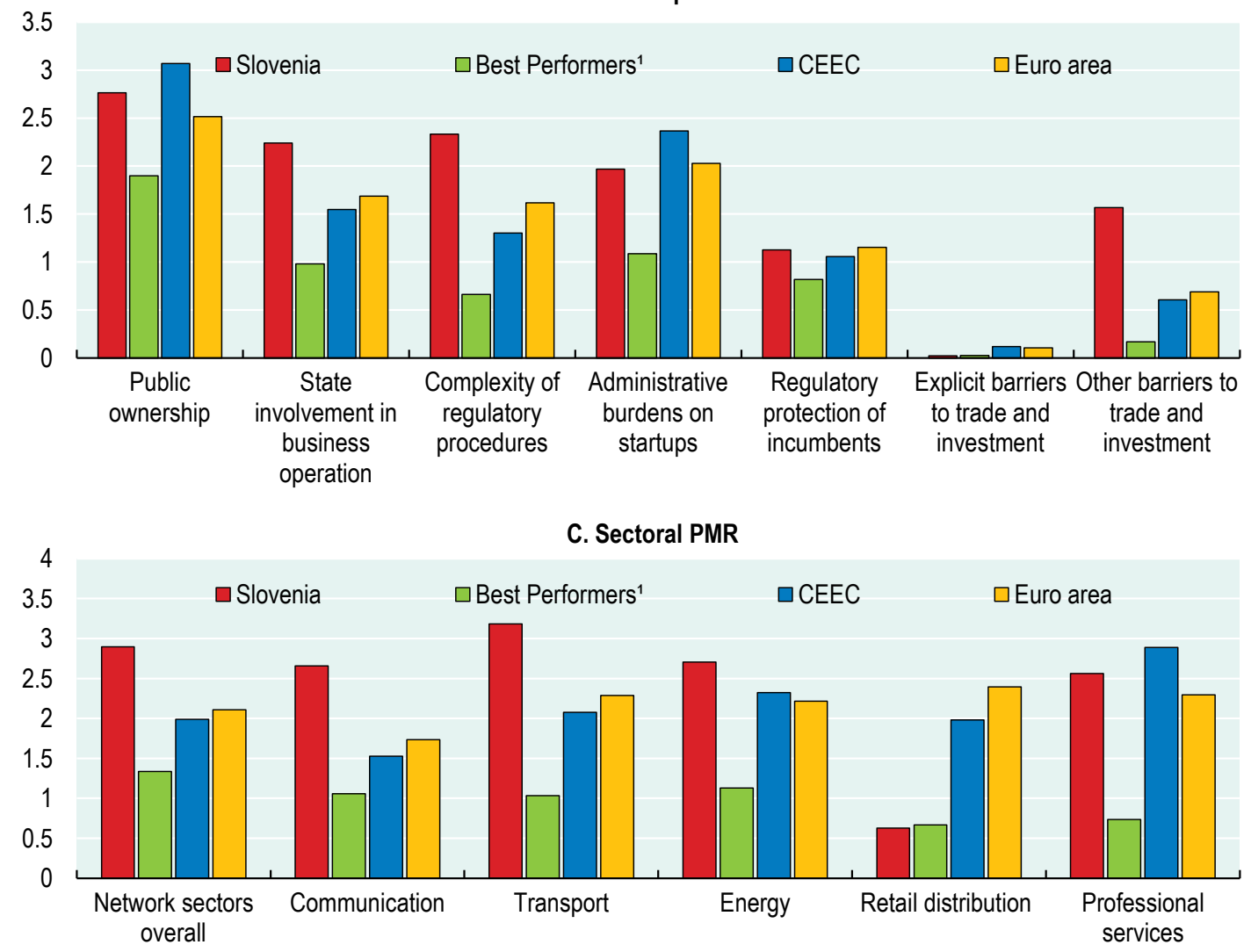

Note: The numerical PMR indicators represent the stringency of regulatory policy in specific areas on a scale of 0 to 6 with a higher number indicating a policy stance that is deemed less conducive to competition. In each case, it characterises the stance of regulation as it stood in early 2013 and does not reflect the reforms implemented since then.

1. Best performers are the five countries with the lowest scores.

Source: OECD PMR indicators database. 


\section{Improving the business environment}

46. The government stepped up efforts to simplify regulatory procedures and administrative burdens when opening a company. The number of regulated professions has decreased from 323 to 242 (European Commission, 2015) and a typical number of days to complete mandatory procedures to register a public limited company was reduced from 20 in 2008 to less than 4 in 2013. Administrative burdens for sole proprietors were reduced even further. In 2013 the government issued a "Single document to enable better regulation and business environment and increase competitiveness" to improve coordination in these efforts, and tasked the Ministry of Economic Development and Technology to implement it. The government is to be notified twice a year on progress (Government of Slovenia, 2013).

47. These reforms are welcome but more is needed. According to the PMR survey, although Slovenia set up single contact points for getting information on all notifications and licenses that are required to open up a business, they have not been sufficiently established at the local level. Furthermore, the single contact points do not issue or accept all notifications and licenses. When setting up a public limited company, entrepreneurs have to complete 13 administrative procedures and they typically need to contact five public (e.g. tax office, one-stop shop), or private (notary/lawyer, bank) bodies to register a company. In Canada for example this was reduced to a single visit to a one-stop shop. Slovenia could introduce the 'silence is consent' rule for issuing licences required to open up a business, as they have been successfully implemented in Portugal and the Slovak Republic.

48. Dealing with construction permits and registering property takes a long time, despite reduced red tape for setting-up new companies. In the Doing Business Survey (World Bank, 2015) Slovenia ranks 26 out of 31 high income OECD economies on registering property (Figure 32). Slovenia ranks at the very bottom among high income OECD countries on the length of time that it takes to register property; 109.5 days in Slovenia compared to one day in Portugal and New Zealand, or 2.5 days in the Netherlands. Time to obtain construction permits in Slovenia takes 212.5 days, more than three times the time in Finland or Denmark, and it is quite costly.

Figure 32 Slovenia ranks low on a number on doing business indicators

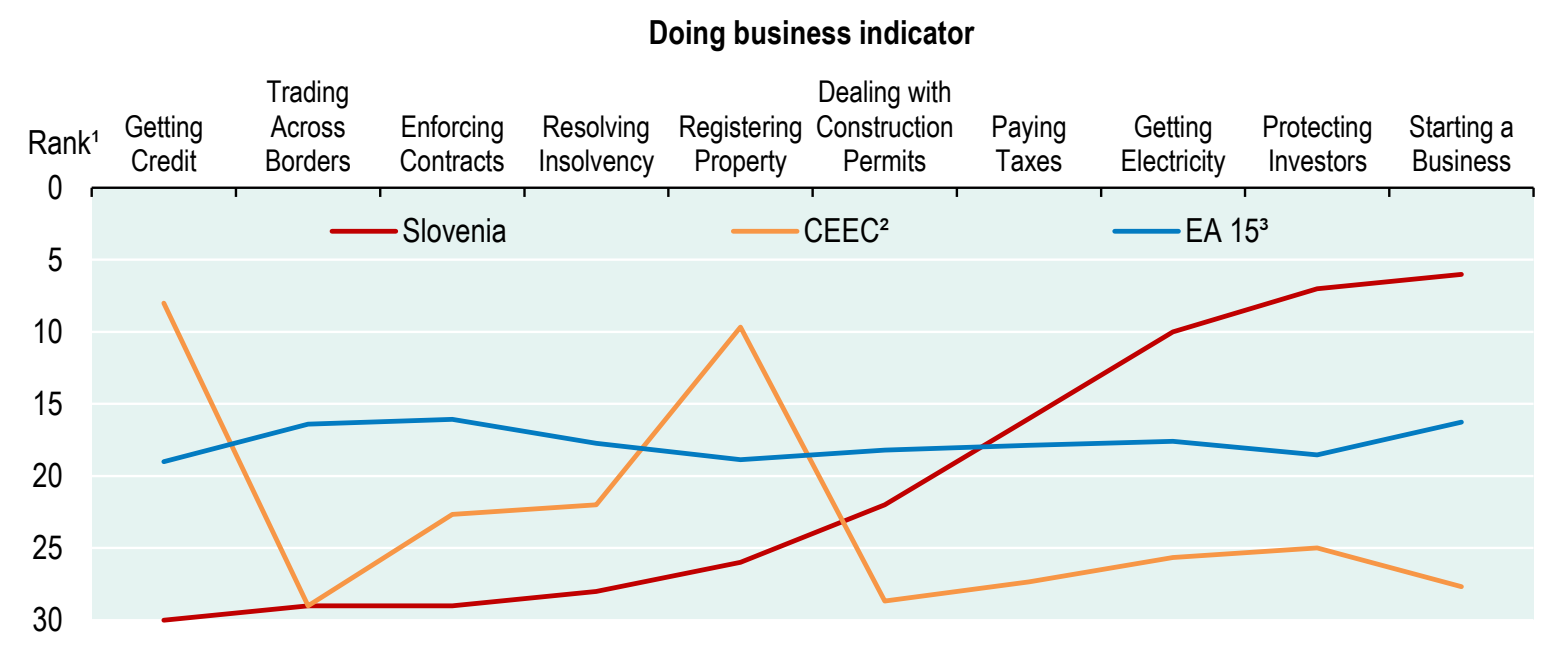

1. Rank among OECD high income countries.

2. Non-weighted average of Slovak Republic, Poland and Czech Republic.

3. Non-weighted average.

Source: World bank Doing business indicator 2015. 
49. Slovenia should further ease regulation of professional services - accounting, legal, engineering and architecture services (Figure 31, panel C). Education requirements to enter a profession are excessively high in Slovenia. According to the PMR survey, to enter fully each of these four professions requires a university degree, in many cases another specialised degree, and compulsory practice lasting up to 5 years. Each profession also requires compulsory membership in a chamber of the profession. Since services sectors are generally less exposed to foreign competition, regulation plays an important role in affecting the quality, variety and price of services through stronger competition. Analysis of productivity across sectors indeed shows that the gap in productivity from the EU15 is one of the biggest for professional services (Figure 5).

50. At the regulatory level, Slovenia has low restrictions to FDI, but there exist high non-tariff barriers to trade and investment (Figure 31, panel B). For example, responses to the PMR questionnaire show that regulations are not systematically published to the international public in a foreign language. There is also evidence that in certain transactions foreign parties are at a disadvantage - e.g. foreign firms may not participate in tenders for government transport contracts. Furthermore, when business practices are perceived to restrict competition, foreign firms cannot seek redress through competition agencies or trade policy bodies, but only by pressing charges through courts.

\section{Public ownership is widespread}

51. Slovenia's unique pattern of firm ownership - low foreign direct investment and high share of state ownership - stems partly from the nature of transition from a socialist economy to a market based economy with private property. At the macro level, the monetary authorities resisted strong capital inflows to reduce appreciation pressures on the currency. Meanwhile, the privatisation process explicitly favoured internal buy-outs by managers and employees and was left incomplete, with the state directly and indirectly retaining large ownership shares in firms across the economy (Domadenik and Prašnikar, 2004; OECD, 2002). Two state-owned funds - pension (KAD) and restitution (SOD) fund - kept controlling stakes in many large "strategic" enterprises. Such structure provided the government with a strong mechanism to influence the boards and management of privatised firms. In part, this was motivated by a desire to manage the extent to which foreign firms gained control over domestic economy (OECD, 2011b).

52. High and widely dispersed internal (managers and employees) ownership and ineffective external ownership provided management with insufficient incentives to restructure enterprises. Internal owners were concerned with keeping their jobs, rather than with maximising profitability, and external owners had insufficient power and incentives to change and monitor management practices (OECD, 2002; OECD, 2011b). There is evidence that productivity growth in transition economies were higher in privatised firms than state-owned firms, as private firms had greater incentives and flexibility to restructure, absorb new technologies and innovate. In particular, privatised firms to outside owners showed significantly better performance than firms with insiders as owners (Frydman et al., 1999; OECD, 2011b).

53. In Slovenia, enterprises directly owned (or indirectly controlled) by the state are most common in network industries, which often have a natural monopoly, but also in banking and insurance, and even manufacturing, where there is no clear public policy role for the state to have a controlling interest (OECD, 2011a). The PMR indicator for the network industries - energy, transport and communication - is high due to strong state dominance (Figure 31, panel C). Government holds majority stakes in the largest company in most network sectors, in particular in telecommunications, postal services, rail transport and airlines. Furthermore, road transport has heavy entry barriers and in postal services the state-owned company plays a dominant role on the market. 
54. The profitability and productivity of state-owned enterprises (SOEs) is lower than of privately and foreign-owned companies operating in same sectors (Rojec, 2014; European Commission, 2014a and 2015). Prices of electricity and telecommunications in Slovenia are relatively low, indicating that heavy state involvement does not lead to excessively high prices. Only in the land transportation sector were mark-ups high (Molnar, 2010). Also, in January 2015 the competition protection agency found that the biggest (state-controlled) supplier of natural gas violated its dominant position in the supply of gas to industrial users, which led to excessive prices. Productivity measured as GVA per employed in the electricity and gas sector in Slovenia is 55\% lower than in the EU15, and significantly below Slovenia's average. Similarly, transportation sector and telecommunications exhibit large gaps in productivity to the EU15.

55. Apart from slowing growth, pervasive state ownership poses risks also to public finances as the losses and high debt levels increase recapitalisation needs, as recently showcased in the banking sector. SOEs are also the main beneficiaries of state guarantees, worth 18\% of GDP in 2013, which constitute a contingent liability for the general government (European Commission, 2015; Georgieva and Riquelme, 2013). There is therefore scope to improve productivity, competition and reduce risks to public finances in these industries by reducing state dominance.

\section{Rationalising public ownership, privatisations and corporate governance}

56. Recently, the government has become more open to privatisation. In 2013, the parliament approved a list of 15 SOEs to be privatised, some in the manufacturing sector, but also an airport, an airline company, one state-owned bank and a major telecom provider. As of April 2015, four companies have been privatised and seven are in the process. Reducing public ownership, ensuring efficient regulation for privatised monopolies and simplifying administrative procedures will attract more foreign direct investment (FDI), improve corporate governance as well as boost competitiveness through direct technology transfers and spill-overs.

57. The government should continue with privatisation. As spelled out in the 2011 Economic Survey of Slovenia, to get the best value for taxpayers, the government should undertake pre-privatisation valuations and make sure that share offerings are not under-priced or targeted to a specific investor group. Privatisation should be subject to independent oversight and high levels of transparency and accountability should be ensured (OECD, 2011a). Besides following through with privatisations, it is important to set up a solid framework for managing the assets that remain in state ownership. Governance problems and interconnectedness of banks with poorly performing public state enterprises also contributed to excessive debt build-up before the crisis.

58. Slovenia has taken significant steps to improve the governance of its SOEs. The 2009 OECD accession review recommended that Slovenia centralises the management of its ownership in the form of an ownership agency, and that the agency should "quickly develop policy instruments that will enable it to successfully execute its function." In 2010, the parliament set up the central ownership agency to manage state assets (OECD, 2011b). Nevertheless, the agency was later scrapped, and a setting up of new sovereign holding company was proposed. Finally, with new legislation enacted in April 2014, the new Slovenian Sovereign Holding (SSH) became fully operational. The role of the SSH is to consolidate and manage all state assets under one structure, and to execute privatisation of some of these assets. The new legislation also includes specific authorisation for SSH to decide on the disposal and voting of shares held by existing funds under state ownership, strengthening its capacity to manage and dispose of remaining state-owned assets (OECD, 2014a). 
59. Effective implementation of the new SSH law is critical to ensure successful ownership oversight. Among the important next steps will be the appointment of professional SSH board members capable of acting with independent judgment in their companies' interests and the development of more detailed plans and policies for the SSH's future operations. The state should not be involved in the day to day management of SOEs and company boards should be composed of experts who can exercise independent and objective judgement; they should be professionals rather than political appointees (OECD, 2011a). It is also important to ensure high quality disclosure and transparency requirements for the remaining SOEs (OECD, 2014a). When setting up its own corporate governance framework for SOEs the SSH should closely follow the OECD's SOE Corporate Governance Guidelines (OECD, 2006). Following examples of Hungary and the Czech Republic, the SSH could also regularly conduct quantitative costbenefit analyses of the merits of retaining the state's existing equity stake for all SOEs (OECD, 2011a).

60. Another priority is to develop an asset management strategy. According to the SSH law, assets are to be classified into three types: strategic, important and portfolio. The minimum share in strategic assets is $50 \%$ plus one vote, in important assets $25 \%$ plus one vote, while the SSH is permitted to freely dispose of portfolio assets. The government is yet to agree on an asset management strategy for assets that will remain under state control, eventually to be confirmed by parliament. It is critical that the strategy provides a rigorous rationale for why certain assets should be owned by the state. There should be a bias against owning assets that are in direct competition with private assets or in markets where there is potential for significant competition (OECD, 2011a).

\section{Less public ownership and deeper capital markets would attract more FDI}

61. FDI has been modest (Figure 33, panel A), despite low direct regulatory restrictions (Figure 31, panel B). Inward stock of FDI is just above $30 \%$ of GDP, less than half the share in Estonia, Hungary or the Czech Republic. Ownership structure and FDI were discussed extensively in the 2011 Economic Survey of Slovenia. The reason for such low FDI, despite the efforts of government to create a friendly regulatory and tax environment, lies in pervasive state ownership and political unwillingness for large privatisations. Analysis in Dall'Orso and Sila (2015) confirms that better business environment has a positive impact on inward FDI and, in particular, lowering state control of the economy is an important factor facilitating FDI (see also Annex 3). At a time when deleveraging in the corporate sector is dragging down investment and activity, opening up more to FDI can attract needed fresh capital.

62. There are a number of channels through which FDI boosts productivity performance. Efficiency gains can come from technology transfers through supply chains, better management practices, better integration with foreign markets, and better human capital formation (OECD, 2011a). A large body of empirical evidence supports this. For example, Bijsterbosch and Kolasa (2009) analyse the experience of central and eastern European countries and find that foreign investment has been an important factor in productivity growth. They also report that productivity benefits have been largest in countries with the greatest absorption capacity for new technologies, either because productivity differential vis-à-vis the euro area was not too big or that there were higher levels of human capital. Damijan, Rojec, Majcen and Knell (2013) compare cohorts of similar foreign and domestic owned firms over time, and find that foreign owned firms persistently outperform domestic firms in terms of TFP growth in the Czech Republic and Slovenia. Our own analysis also shows that FDI has a positive effect on productivity and on R\&D activity (Dall'Orso and Sila, 2015 and Annex 3). 
Figure 33 FDI has remained low
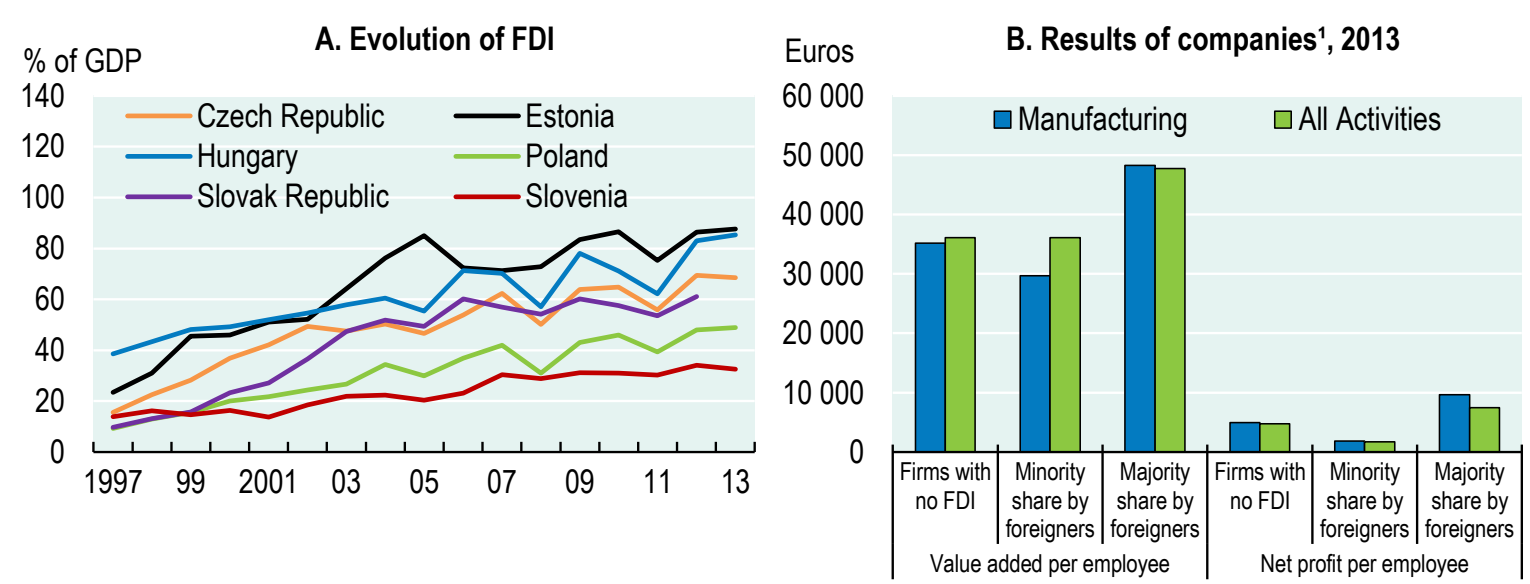

1. A firm is classified "Firms with no FDI" if less than $10 \%$ of its equity shares belong to foreign investors; a firm is classified "Minority share by foreigners" if more than $10 \%$ and less than $50 \%$ of its equity shares belong to foreign investors; a firm is classified "Majority share by foreigners" if more than $50 \%$ of its equity shares belong to foreign investors.

Source: OECD FDI series of BOP and IIP aggregates database for panel A; and Bank of Slovenia for Panel B.

63. Companies with FDI perform better than domestically owned ones. Data from the Bank of Slovenia (2014b) show that about $4.5 \%$ of all non-financial companies have FDI, but they account for $19 \%$ of capital, $23 \%$ of assets and $22 \%$ of employees in the entire corporate sector. Companies with a majority share held by foreigners - representing $82 \%$ of all firms with FDI - have significantly higher productivity and higher profit per employees than domestically owned companies (Figure 34, panel B). Firms with FDI also offer on average about $12 \%$ higher wages. Comparing raw data however, may exert a bias as foreign investors may be cherry-picking firms in better condition and with better growth potential. Yet, even after controlling for this, Simoneti et al. (2002) find evidence that foreign owned companies in Slovenia experienced more rapid asset, sales, exports, value added and employment growth than domestic enterprises in mid 1990s.

64. A consequence of state dominance is that the legal and regulatory architecture of private capital markets are not well developed (OECD, 2011b). Slovenia is characterised by a shallow and relatively illiquid capital market. Total equity capitalisation and average monthly turnover are both low in comparison to other EU countries (Figure 34). The legal framework in Slovenia provides a relatively high degree of protection for shareholders, but in practice minority shareholders are widely dispersed and have limited economic interests in companies. To exercise their rights, shareholders must have a threshold level of voting interest (either 5 or $10 \%$ ), meaning that often only the larger shareholders have the practical means to seek some form of redress. The extent to which duties of directors in companies can be enforced has been limited. This is reflected in the very low number of cases that have been heard for breach of directors' duties and their low rates of success (OECD, 2011b). 
Figure 34 Equity market capitalisation and turnover - 2013'
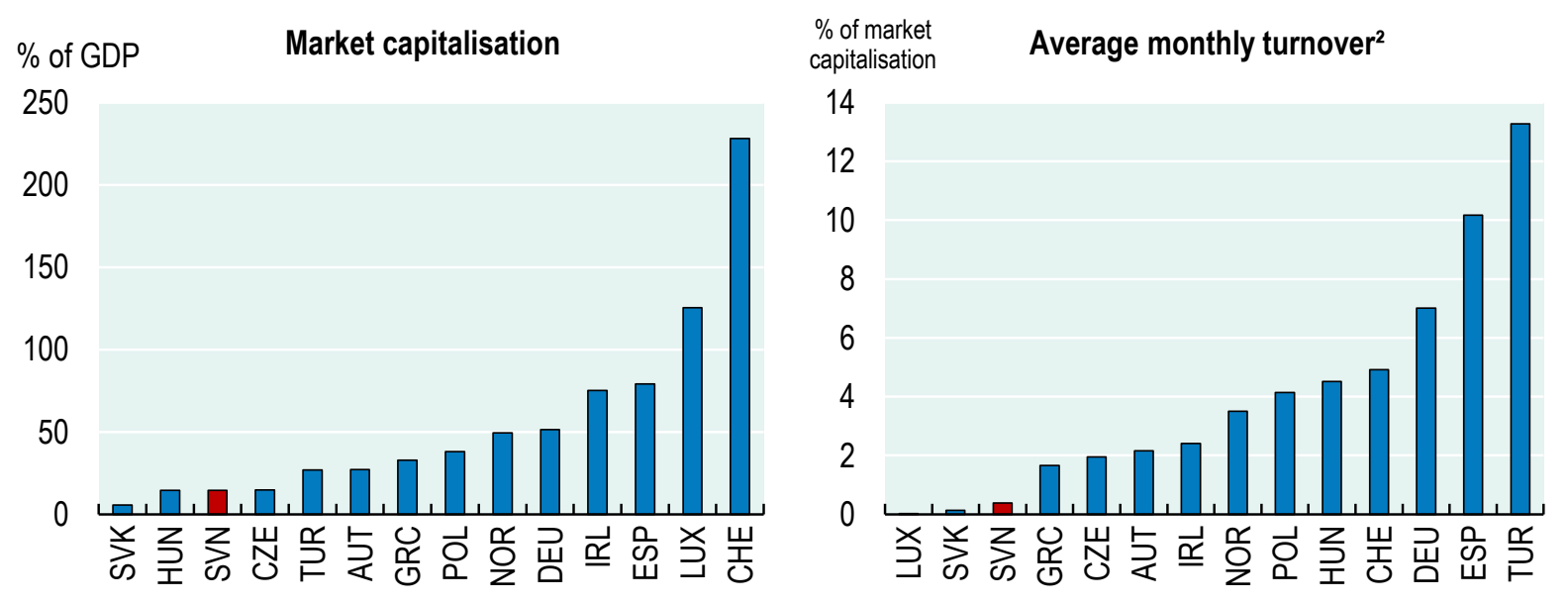

1. December 2013 for market capitalisation.

2. Value of equity trading in the year to December 2013

Source: Federation of European Securities Exchanges.

65. A number of questionable buyout and takeover transactions in the past suggest that there have been difficulties in appropriately regulating the capital markets. Legislative amendments improved operational independence of the Securities Market Agency (SMA) and there have been improvements in the quality of enforcement. However, annual budget plans of the SMA are subject to government approval, and its employees remain subject to public employment regulations that prevent them from receiving market based salaries (OECD, 2013b). It remains important to ensure the Securities Market Agency has the financial and operational independence to adequately exercise its function.

\section{The competition framework could be strengthened}

66. With respect to anticompetitive agreements, Slovenia's law largely tracks the EU's competition law. However, its approach with respect to abuse of a dominant position may result in an overabundance of cases in which there is no competition problem from the perspective of effects-based economic analysis (OECD, 2014a). There were also recurrent complaints that resources of the competition authority have been inadequate, which has limited its potential to recruit and retain experienced and well-trained staff. The Competition Protection Agency's (CPA) annual budget must be negotiated with the competent ministry and approved by the government, limiting its financial and operational independence.

67. Progress has been made in improving budgetary autonomy for the Competition Protection Agency and in maintaining its independence (European Commission, 2015). Slovenia implemented several amendments to its competition law in 2012 and 2013. In January 2013 a new, independent public agency, the Slovenian Competition Protection Agency (CPA), took over the responsibility for enforcing the competition law. In 2013 the budget of the CPA was increased to address resource issues, and CPA was able to recruit more people. Nevertheless, with 27 full time equivalent employees covering competition enforcement, CPA is the smallest in the European Union, and far below the EU average of 116 people. 


\section{Recommendations on product market regulation and business environment}

\section{Key recommendations}

- Continue privatising state-owned enterprises and do not hold controlling interests in firms operating in competitive markets.

- Introduce the 'silence is consent' rule for issuing licences required to open up a business and make obtaining construction permits and registering property faster.

\section{Other recommendations}

- Prepare an asset management strategy for assets in public ownership and strengthen the corporate governance of SOEs by appointing professional board members.

- Reduce entry barriers in professional services (accounting, legal, engineering and architecture).

\section{Tax system that better supports growth}

\section{Relatively high tax burden is primarily levied on consumption and labour}

68. Slovenia relies to a large extent on the taxation of labour (personal income tax and social security contributions) and consumption while capital and property are relatively lightly taxed. The total tax take - 37\% of GDP in 2013 - is relatively high; above the OECD average of 34\%, close to levels in countries with higher level of development such as Iceland, Germany or Luxembourg. In 2013 almost 80\% of tax revenues were collected from social security contributions and from taxes on goods and services while revenues from personal income tax amounted to about 14\% and from corporate income to about 3\% (Figure 35).

Figure 35 Relatively high tax burden is primarily levied on consumption and labour

Year 2013 or latest data available

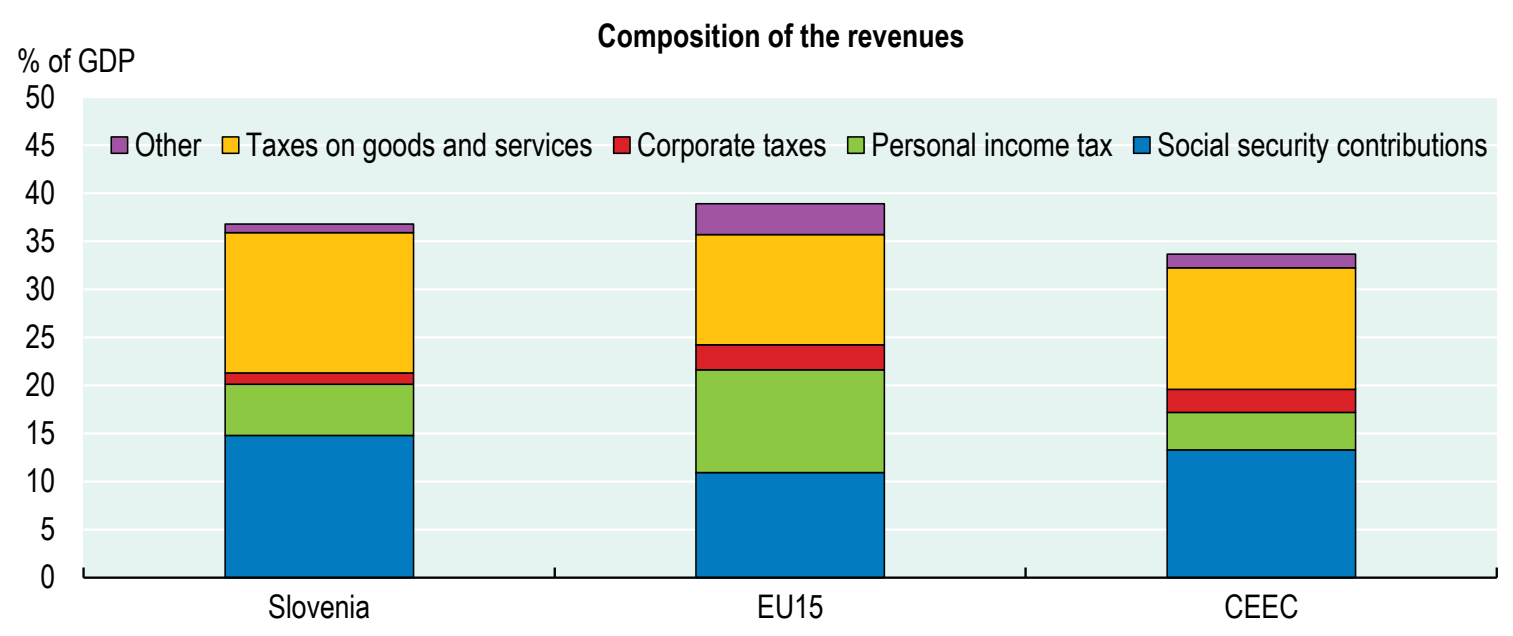

Source: OECD Public Sector, Taxation and Market Regulation database. 
69. Slovenia could reform its tax system in a revenue-neutral manner to better support inclusive and sustainable growth. Arnold et al. (2011) find that recurrent taxes on immovable property are least harmful to growth, followed by consumption taxes (and other property taxes). Taxes on production factors labour and capital (personal income taxes and corporate income taxes) are most harmful to growth. Therefore, Slovenia has room to reduce taxes on labour, and compensate with increases in property taxes and changes in indirect consumption taxes.

70. To attract investment Slovenia has been cutting the corporate income tax rate over the last 10 years, from 25\% in 2005 to $17 \%$ in 2013, the second lowest in the OECD (OECD, 2014a). Measures have been taken to broaden the tax base, although tax incentives for investment have been introduced which narrow the tax base, for example via research and development (R\&D) and investment tax allowances (2009 and 2013 Economic Surveys). While low rates of corporate income tax support investment - also from abroad - and total factor productivity growth in the medium term, another issue worth considering is that lowering the corporate tax rate too much below the top personal income tax rate can prompt highincome individuals to shelter their savings within corporations (Arnold et al., 2011). Therefore, given the current fiscal position and the fact that intake from the current tax is already quite low there is no room for further cuts in the corporate income tax rate.

\section{Reducing tax rates on labour income}

71. The tax on labour is relatively high due to high social security contributions and a progressive personal income tax. Reducing marginal tax rates on labour income should be Slovenia's top priority for tax reform to increase incentives to work. The marginal tax wedge - the share of an extra euro of labour costs that is kept by the government through personal income taxes and employee and employer social security contributions - is high across the income distribution (Figure 36). At 67\% of average earnings for a person with no children it stands at $43.6 \%$, above the OECD average, while it stands at $60.4 \%$ for a person earning $167 \%$ of average earnings, one of the highest in the OECD. After introducing the additional $50 \%$ tax bracket for those earning more than 5 times the average wage - a temporary measure introduced in 2013 to help fiscal consolidation - the marginal tax wedge for top earners stands at 66\% (OECD, 2014a). Yet, Guner et al. (2014) find that increasing progressivity of the personal income tax brings very little in terms of additional government revenue.

72. Certain groups of workers are especially sensitive to changes in taxation on labour. The tax wedge on low wages increases labour costs of employing low-skilled and young workers, reducing their employment opportunities. The situation is aggravated in Slovenia with the very high minimum wage. High tax wedges can also induce people to stay on social benefits rather than work, and it has been shown that in Slovenia average effective tax rates when returning to work from unemployment and inactivity are high. High labour taxes also have adverse effects on labour participation of older workers and add to incentives for early retirement. The relatively high labour tax wedge on high wage earners also bears the risk of brain drain of highly qualified workers or prevents firms from attracting talent from abroad.

73. Reducing the tax wedge on labour would therefore encourage hiring, labour force participation and investment in skills (OECD, 2011c). This could be achieved by reducing the top marginal income tax. This can be reformed in a consistent manner together with reducing eligibility of high earners for various social benefits not to increase inequality. The progressivity of cash transfers is relatively low in Slovenia (Joumard et al., 2012; OECD, 2014g). With the 2012 reform, the eligibility of high-income earners for cash transfers was reduced by taking into account all income and also property of individuals and families. But better means testing could further reduce the share of high-income earners eligible for support. 
Figure 36 Marginal tax wedge is high

$\%$ of total earnings of a single person with no children
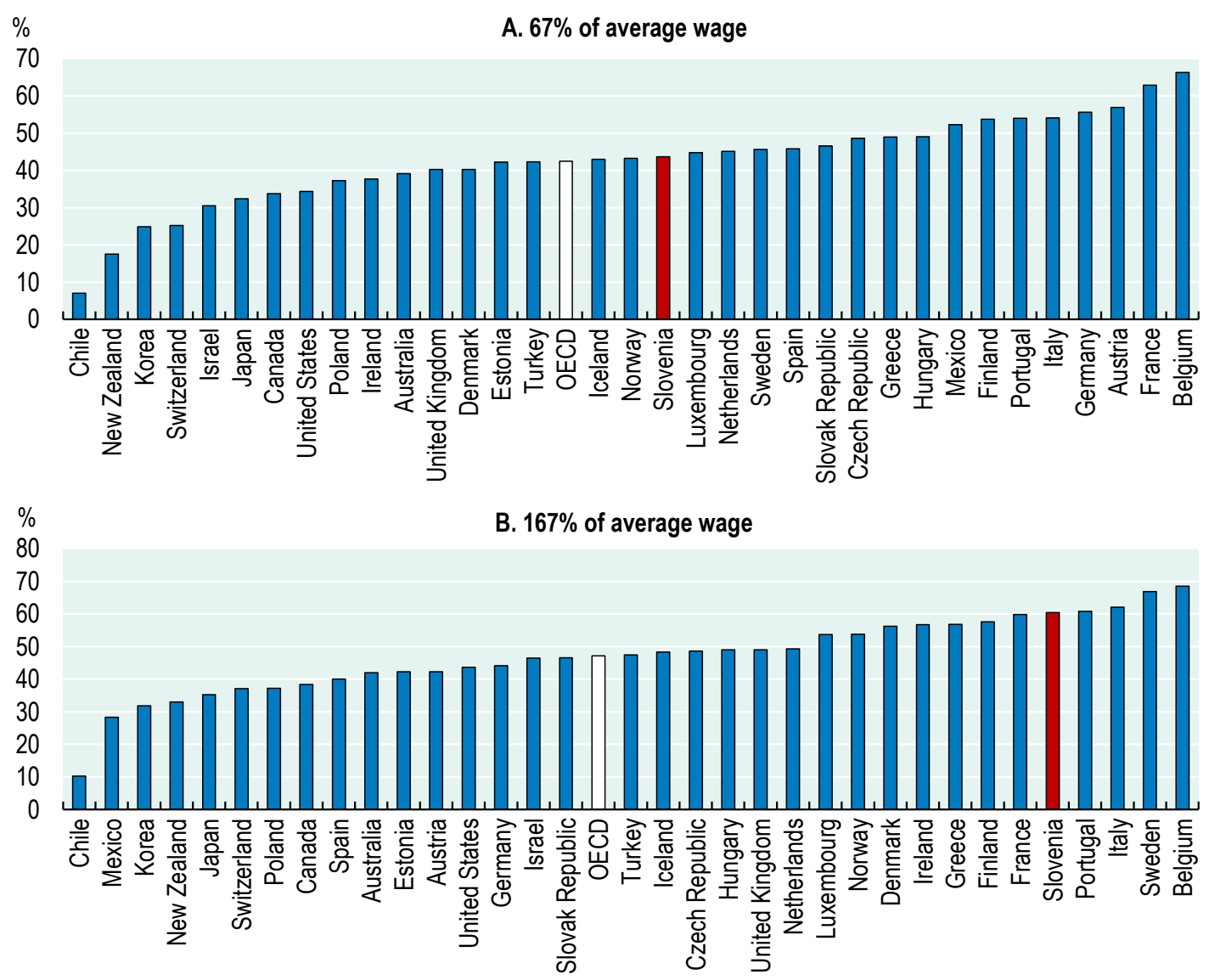

Source: OECD Taxing Wages (2014).

\section{Increasing the reduced VAT rates and making tax expenditures fairer}

74. The reductions in marginal tax rates on labour could be financed by raising taxes on consumption and reducing various tax expenditures, while preserving the equity-friendly nature of the tax system. As discussed in OECD (2014a), Slovenia could convert some personal income tax deductions (e.g. for social security contributions and for dependent children) into tax credits, to reduce the financial benefit of tax expenditures on individuals in high income brackets. It could remove exemptions and other tax preferences for certain forms of income (e.g. severance pay, pensions and capital gains on long-held assets), and consider shifting from flat-rate taxation of personal capital income to more progressive rates.

75. There is also room for increases in indirect taxes on consumption. At $22 \%$, the standard valueadded tax (VAT) rate is already high, but Slovenia applies a reduced VAT rate $(9.5 \%)$ to quite a wide range of goods and services. For goods and services that are disproportionately consumed by higherincome households such as books, cultural services, hotels and restaurant meals, the reduced VAT rate could be removed and the standard VAT rate applied instead. 
76. Improvements in tax compliance and mitigation of the shadow economy are also important to sustain tax revenues. The European Commission (2014c) assesses that Slovenia has made progress on this front and there are indications that the government programme, introduced in 2013, has yielded positive results. Undeclared employment has been addressed through the introduction of special online voucher register and tax fraud has been checked through stricter rules for using cash-register software. The government has also devoted attention to improving the tax culture and encouraging the voluntary, correct and prompt payment of taxes (Government of Slovenia, 2014).

\section{Increasing taxes on real estate}

77. The recurrent taxation of residential and other real estate is a key element of a tax system that supports inclusive and sustainable growth. This form of taxation has been found to have relatively limited negative effects on economic growth (Arnold et al., 2011). The tax revenues from taxes on property in 2013 were a mere $0.7 \%$ of GDP, about one third of the 2012 OECD average (Figure 37), so there is ample room to increase this tax. In fact, Slovenia had enacted a Real Estate Tax Law in 2014, but this law was proclaimed unconstitutional by the Constitutional Court. Slovenian government plans to prepare an alternative property tax reform with the same policy objectives while satisfying legal requirements, which we see as a positive step.

Figure 37 There is room to raise recurrent taxes on real estate

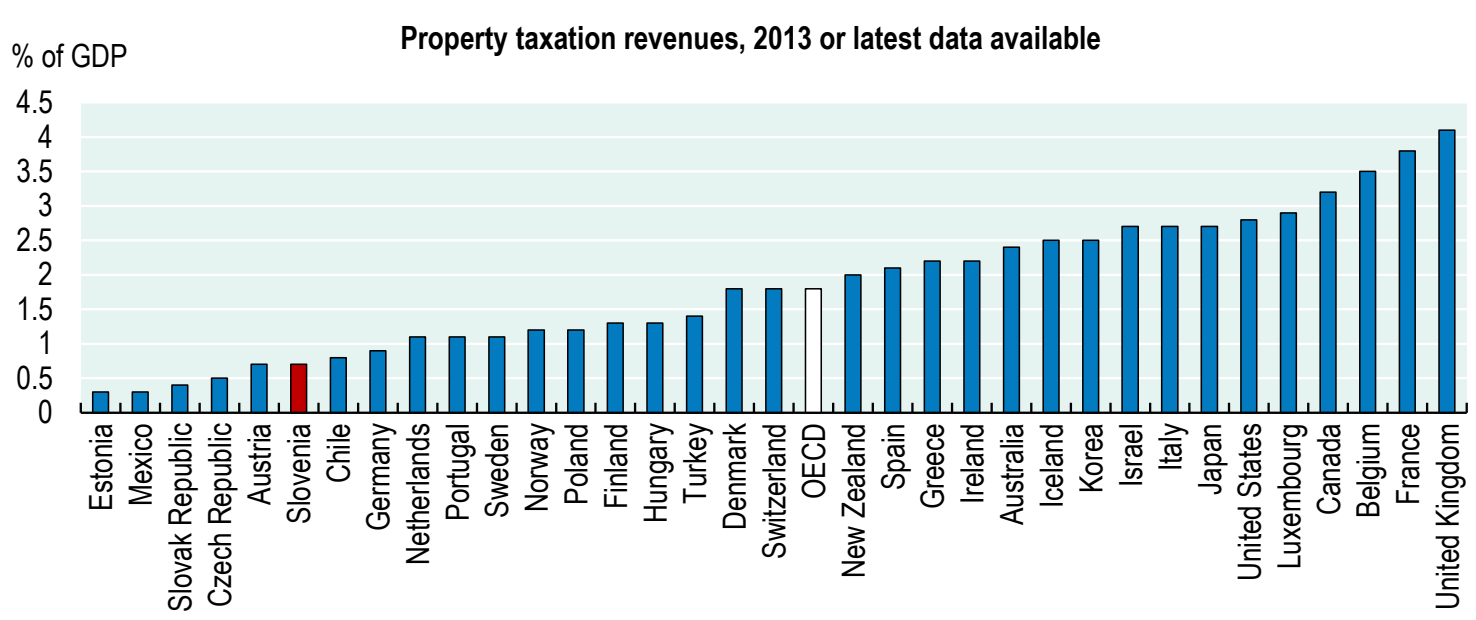

Source: Public Sector, Taxation and Market Regulation database.

\section{Aligning tax rates on different forms of energy}

78. Revenues from environmental taxes amounted to 3.9\% of GDP in 2013, one of the highest ratios among the OECD countries (OECD Environment Database). While overall effective tax rates on energy are at or above the OECD average, high revenues stem also from high fuel consumption associated with transit traffic (OECD, 2013i). Nevertheless, effective tax rates vary across different forms of energy. Tax rates on transport fuel are significantly higher than those on heating and process use and on electricity, and those on diesel are about $20 \%$ below those on gasoline in terms of energy content and carbon dioxide $\left(\mathrm{CO}_{2}\right)$ emissions, respectively (OECD, 2013i; Ministry of Finance). The differential between diesel and gasoline has been reduced recently due to reduced differential in excise duties on the two fuels. In addition, effective from January 2015, there was an increase in tax rate on $\mathrm{CO} 2$ emissions by $20 \%$ per each $\mathrm{kg}$ of $\mathrm{CO} 2$ for all energy products. Slovenia could therefore improve the environmental effectiveness of these taxes by linking them further to emissions. It should also for example remove exemptions in the case of commercial use of diesel fuel and increase taxes on heavy fuel oil and gas oil used for heating. 


\section{Recommendations on the tax system}

- Reduce top tax rates on labour income. Better target family benefits and strengthen means testing of education-related benefits.

- Reduce tax expenditures and the use of reduced VAT rates in an equity-friendly manner.

- Increase recurrent taxes on real estate.

- Further align effective tax rates on different forms of energy to reflect environmental damage.

\section{BIBLIOGRAPHY}

Arnold, J., B. Brys, C. Heady, Å. Johansson, C. Schwellnus and L. Vartia (2011), "Tax Policy for Economic Recovery and Growth”, The Economic Journal, Vol. 121, No. 550.

Bai, J., Perron, P., (1998) "Estimating and Testing linear models with multiple structural changes", Econometrica, Vol. 66, No. 1.

Bank of Slovenia (2014a), Macroeconomic Developments and Projections, October.

Bank of Slovenia (2014b), Direct Investment 2013, Bank of Slovenia, Ljubljana.

Bank of Slovenia (2013), Macroeconomic Developments and Projections, October.

Bijsterbosch, M. and M. Kolasa (2009), "FDI and Productivity Convergence in Central and Eastern Europe: An Industry-Level Investigation”, Working Paper Series, No. 992, European Central Bank, Frankfurt am Main.

Bouis, R. and R. Duval (2011), "Raising Potential Growth After the Crisis: A Quantitative Assessment of the Potential Gains from Various Structural Reforms in the OECD Area and Beyond", OECD Economics DepartmentWorking Papers, No. 835, OECD Publishing, Paris.

Bourlès, R., J. Cette, J. Lopez Mairesse and G. Nicoletti (2010), "Do Product Market Regulations in Upstream Sectors Curb Productivity Growth: Panel Data Evidence for OECD Countries", OECD Economics DepartmentWorking Papers, No. 791, OECD Publishing, Paris.

Chetty R. (2008), "Moral Hazard vs. Liquidity and Optimal Unemployment Insurance", Journal of Political Economy, University of Chicago Press, vol. 116(2), pages 173-234, 04.

Clemens, J and M Wither (2014), "The Minimum Wage and the Great Recession: Evidence of Effects on the Employment and Income Trajectories of Low-Skilled Workers", National Bureau of Economic Research, Working Paper 20724.

Conway, P., D. de Rosa, G. Nicoletti, and F. Steiner (2006), "Regulation, Competition and Productivity Convergence", OECD Economics DepartmentWorking Papers, No. 509, OECD Publishing, Paris.

Čelebič T. (2014), "Tertiary education in Slovenia- participation, efficiency, quality, financing and employability", Working Paper 4/2014, Vol. XXIII 
Dall'Orso, J. and U. Sila (2015), "Trends in productivity and sources of productivity growth in Slovenia”, OECD Economics department, mimeo.

Damijan, J., Č. Kostevc and M. Rojec (2013). FDI, Structural Change and Productivity Growth: Global Supply Chains at Work in Central and Eastern European Countries. IRMO OCCASIONAL PAPERS.

Damijan, J.P., M. Rojec, B. Majcen and M. Knell (2013), "Impact of firm heterogeneity on direct and spillover effects of FDI: Micro-evidence from ten transition countries" Journal of Comparative Economics, Vol 41 (3), Pages 895-922.

Domadenik, P. and J. Prašnikar (2004), "Enterprise Restructuring in the First Decade of Independence" in Mrak, M. et al. (eds.), Slovenia: From Yugoslavia to European Union, World Bank, Washington, DC.

Eissa, N and H W Hoynes (2006), "Behavioral Responses to Taxes: Lessons from the EITC and Labour Supply", in Tax Policy and the Economy, Volume 20:73-110.

EIU (Economist Intelligence Unit) (2009), A New Ranking of the World's Most Innovative Countries, TheEconomist, London.

European Commission (2015), Commission staff working document: Country Report Slovenia 2015. Brussels, 26.5.2015.

European Commission (2014a), Macroeconomic Imbalances, Slovenia 2014. Occasional Papers 187, March 2014.

European Commission (2014b), Innovation Union Scoreboard 2014.

European Commission (2014c), Commission staff working document: Assessment of the 2014 national reform programme and stability programme for Slovenia.

European Commission (2013), Research and Innovation performance in Slovenia, Country Profile.

European Commission (2010), Employers' perception of graduate employability, Eurobarometer.

European Commission/EACEA/Eurydice/Eurostat (2014), Key Data on Early Childhood Education and Care in Europe. 2014 Edition. Eurydice and Eurostat Report. Luxembourg: Publications Office of the European Union.

Eurydice (2011), "Chapter 3: Student fees and support", Modernisation of Higher Education in Europe 2011: Funding and the Social Dimension,

Farčnik, D. and P. Domadenik (2009), "School to Work Transition: Evidence from a Matched EmployerEmployee Dataset", paper presented at the European Economics and Finance Society conference, University of Warsaw, 4-7 June.

Frydman, R., C. Gray, M. Hessel and A. Rapaczynski (1999). When does privatization work? The impact of private ownership on corporate performance in the transition economies. The Quarterly Journal of Economics 114, 1153-1191. 


\section{ECO/WKP(2015)59}

Georgieva, S. and D. M. Ruqielme, (2013) "Slovenia: State-Owned and State-Controlled Enterprises", ECFIN Country Focus, Volume 10, issue 3.

Global Entrepreneurship Monitor (2015a): 2014 Global Report.

Global Entrepreneurship Monitor (2015b), Leveraging Entrepreneurial Ambition and Innovation: A Global Perspective on Entrepreneurship, Competitiveness and Development.

Government of the Republic of Slovenia (2014), Stability Programme, Amendments 2014, Ljubljana, April 2014.

Government of Slovenia (2013), Single document to enable better regulation and business environment and increase competitiveness, No. 01005-2/2013/11.

Guner, N., M. Lopez-Daneri and G. Ventura (2014), "Heterogeneity and Government Revenues: Higher Taxes at the Top?”, IZA Discussion Paper No. 8335, July 2014.

Hanushek, E. and L. Wößmann (2008), "The Role of Cognitive Skills in Economic Development”, Journal of Economic Literature, Vol. 46, No. 3, pp. 607-68, September.

Hanushek, E. and L. Wößmann (2011), "How Much do Educational Outcomes Matter in OECD countries?”, Economic Policy, CEPR, CES, MSH, Vol. 26, No. 67, pp. 427-91.

Hattie, J. (2009), Visile Learning; A synthesis of over 800 meta-analyses relating to achievement, Routledge, London.

Hausmann, R. and C.A. Hidalgo (2011). The network structure of economic output. Journal of Economic Growth.

IMAD (2014a), Slovenian economic mirror, December 2014, no. 12, Vol. XX.

IMAD (2014b), Economic Issues 2014, August, Institute of Macroeconomic Analysis and Development, Ljubljana.

IMAD (2010), Development Report 2010, Institute of Macroeconomic Analysis and Development, Ljubljana.

Initiative start: up Slovenia (2014), Start:up Manifesto.

Institut RS za socialno varstvo (2014): Socialni polozaj v Sloveniji 2013-2014.

Joumard, I., M. Pisu and D. Bloch (2012), "Less Income Inequality and More Growth - Are They Compatible? Part 3. Income Redistribution via Taxes and Transfers Across OECD Countries", OECD Economics Department Working Papers, No. 926, OECD Publishing.

Lovea, J. H., \& Ganotakisb, P. (2013). Learning by exporting: Lessons from high-technology SMEs. International Business Review.

Ministry of higher education, science and technology (2014), website:

http://www.arhiv.mvzt.gov.si/en/areas_of_work/science_and_technology/centres_of_excellence_and _competence_centres/ 
Ministry of higher education, science and technology (2010): Resolution on research and innovation strategy of Slovenia 2011-2020, Republic of Slovenia.

Ministry of education, science and sport (2014): Some explanations and comments to the findings and recommendations of "OECD Better Policies Series: Slovenia, Reforms for a strong and sustainable recovery, May 2014”, mimeo.

Molnar, M. (2010), "Measuring Competition in Slovenian Industries - Estimation of Mark-ups", OECD Economics Department Working Paper No. 787.

Nicoletti, G. and S. Scarpetta (2005), "Product Market Reforms and Employment in OECD Countries", OECD Economics Department Working Papers, No. 472, OECD Publishing, Paris.

OECD (2015), Education Policy Outlook 2015: Making Reforms Happen, OECD Publishing, Paris. DOI: http://dx.doi.org/10.1787/9789264225442-en

OECD (2014a), Slovenia: Reforms for a Strong and Sustainable Recovery, Better Policies, OECD Publishing, Paris.

DOI: http://dx.doi.org/10.1787/9789264215894-en

OECD (2014b), Education at a Glance 2014: OECD Indicators, OECD Publishing, Paris. DOI: http://dx.doi.org/10.1787/eag-2014-en

OECD (2014c), Entrepreneurship at a Glance 2014, OECD Publishing, Paris.

DOI: http://dx.doi.org/10.1787/entrepreneur_aag-2014-en

OECD (2014d), OECD Economic Surveys: Finland 2014, OECD Publishing, Paris.

DOI: http://dx.doi.org/10.1787/eco_surveys-fin-2014-en

OECD (2014e), OECD Science, Technology and Industry Outlook 2014, OECD Publishing, Paris. DOI: http://dx.doi.org/10.1787/sti_outlook-2014-en

OECD (2014f), Main Science and Technology Indicators, Vol. 2014/1, OECD Publishing, Paris. DOI: http://dx.doi.org/10.1787/msti-v2014-1-en

OECD (2014g), "The crisis and its aftermath: A stress test for societies and for social policies", in OECD, Society at a Glance 2014: OECD Social Indicators, OECD Publishing, Paris.

DOI: http://dx.doi.org/10.1787/soc_glance-2014-5-en.

OECD (2013a), Interconnected Economies: Benefiting from Global Value Chains, OECD Publishing, Paris.

DOI: http://dx.doi.org/10.1787/9789264189560-en

OECD (2013b), OECD Economic Surveys: Slovenia 2013, OECD Publishing, Paris.

DOI: http://dx.doi.org/10.1787/eco_surveys-svn-2013-en

OECD (2013c), PISA 2012 Results: Excellence through Equity (Volume II): Giving Every Student the Chance to Succeed, PISA, OECD Publishing, Paris.

DOI: http://dx.doi.org/10.1787/9789264201132-en

OECD (2013d), OECD Economic Surveys: Switzerland 2013, OECD Publishing, Paris.

DOI: http://dx.doi.org/10.1787/eco_surveys-che-2013-en 
OECD (2013e), "Slovenia", in OECD, Education at a Glance 2013: OECD Indicators, OECD Publishing, Paris.

DOI: http://dx.doi.org/10.1787/eag-2013-70-en

OECD (2013f), OECD Science, Technology and Industry Scoreboard 2013: Innovation for Growth, OECD Publishing, Paris.

DOI: http://dx.doi.org/10.1787/sti_scoreboard-2013-en

OECD (2013g), OECD Economic Surveys: Ireland 2013, OECD Publishing, Paris.

DOI: http://dx.doi.org/10.1787/eco_surveys-irl-2013-en

OECD (2013h), Entrepreneurship at a Glance 2013, OECD Publishing, Paris.

DOI: http://dx.doi.org/10.1787/entrepreneur_aag-2013-en

OECD (2013i), Taxing Energy Use: A Graphical Analysis, OECD Publishing, Paris.

DOI: http://dx.doi.org/10.1787/9789264183933-en

OECD (2012a), OECD Economic Surveys: Finland 2012, OECD Publishing, Paris.

DOI: http://dx.doi.org/10.1787/eco_surveys-fin-2012-en

OECD (2012b), OECD Science, Technology and Industry Outlook 2012, OECD Publishing, Paris.

DOI: http://dx.doi.org/10.1787/sti_outlook-2012-en

OECD (2012c), OECD Reviews of Innovation Policy: Slovenia 2012, OECD Publishing, Paris.

DOI: http://dx.doi.org/10.1787/9789264167407-en

OECD (2011a), OECD Economic Surveys: Slovenia 2011, OECD Publishing, Paris.

DOI: http://dx.doi.org/10.1787/eco_surveys-svn-2011-en

OECD (2011b), Corporate Governance in Slovenia 2011, Corporate Governance, OECD Publishing, Paris. DOI: http://dx.doi.org/10.1787/9789264097704-en

OECD (2011c), Taxation and Employment, OECD Tax Policy Studies, No. 21, OECD Publishing, Paris. DOI: http://dx.doi.org/10.1787/9789264120808-en

OECD (2010a), PISA 2009 Results: Overcoming Social Background: Equity in Learning Opportunities and Outcomes (Volume II), PISA, OECD Publishing, Paris.

DOI: http://dx.doi.org/10.1787/9789264091504-en

OECD (2010b), Learning for Jobs, OECD Reviews of Vocational Education and Training, OECD Publishing, Paris.

DOI: http://dx.doi.org/10.1787/9789264087460-en

OECD (2009a), OECD Economic Surveys: Slovenia 2009, Pp 26-34 and 47-49. OECD Publishing, Paris. DOI: http://dx.doi.org/10.1787/eco_surveys-svn-2009-en

OECD (2009b), Creating Effective Teaching and Learning Environments: First Results from TALIS,

TALIS, OECD Publishing, Paris.

DOI: http://dx.doi.org/10.1787/9789264068780-en 
OECD (2007), PISA 2006: Science Competencies for Tomorrow's World: Volume 1: Analysis, PISA, OECD Publishing, Paris.

DOI: http://dx.doi.org/10.1787/9789264040014-en

OECD (2006), "OECD Guidelines on Corporate Governance of State-owned Enterprises", in OECD, Corporate Governance of State-Owned Enterprises: A Survey of OECD Countries, OECD Publishing, Paris.

DOI: http://dx.doi.org/10.1787/9789264009431-10-en.

OECD (2005), OECD Employment Outlook 2005, OECD Publishing, Paris. DOI: http://dx.doi.org/10.1787/empl_outlook-2005-en.

OECD (2002), OECD Investment Policy Reviews: Slovenia 2002, OECD Publishing, Paris. DOI: http://dx.doi.org/10.1787/9789264196162-en.

Rojec, M., (2014) “A snapshot of the main ownership features of the Slovenian corporate sector, IB Revija $1 / 2014$.

Sala-i-Martin, X., G. Doppelhofer and R. Miller (2004), "Determinants of Long-Term Growth: A Bayesian Averaging of Classical Estimates (BACE) Approach", American Economic Review, Vol. 94, No. 4, pp. 813-35, September.

Simoneti, M., M. Rojec and M. Rems (2002), "Ownership Structure and Post-Privatisation Performance and Restructuring of the Slovenian Non-Financial Corporate Sector", Journal of East-West Business, Vol. 7, No. 2, Routledge.

SORS (2012), Collection brochures: Education in Slovenia, September 2012.

Sutherland, D. and R. Price (2007), "Linkages Between Performance and Institutions in the Primary and Secondary Education Sector”, OECD Economics Department Working Papers, No. 558.

Šušteršič J., B. Nastav and T. Kosi (2010), "Ekonomski vidiki študentskega dela" (Economic Aspects of Student Work), Faculty of Management Koper, University of Primorska.

World Bank (2015), Doing Business Survey 2015. 
ANNEX 1

\section{NAMING OF ECONOMIC SECTORS}

Following the Eurostat NACE (revision 2) decomposition, we named the sectors according to the table below.

\begin{tabular}{lll}
\hline Code & \multicolumn{1}{c}{ Name } & Short name \\
\hline A & Agriculture, forestry and fishing & Agriculture \\
\hline BDE & Mining and utilities & Mining and utilities \\
\hline C & Manufacturing & Manufacturing \\
\hline F & Construction & Construction \\
\hline G-I & Wholesale and retail trade, transport, accomodation and food service activities & Wholesale, retail and transport \\
\hline J & Information and communication & Information and communication \\
\hline K & Financial and insurance activities & Finance and insurance \\
\hline $\mathbf{L}$ & Real estate activities & Real estate \\
$\mathbf{M - N}$ & Professional, scientific and technical activities; administrative and support service activities & Professional services \\
\hline $\mathbf{O}-\mathbf{Q}$ & Public administration, defence, education, human health and social work activities & Public sector \\
\hline $\mathbf{R}-\mathbf{U}$ & Arts, entertainment and recreation; other service activities; activities of household and & Arts, entertainment and recreation \\
\hline
\end{tabular}


ECO/WKP(2015)59

\section{ANNEX 2 \\ STRUCTURAL BREAKS IN PRODUCTIVITY GROWTH}

Before the crisis, Slovenia experienced a continuous growth in productivity, while in the last quarters of 2008 the country suffered from an unprecedented productivity drop (Figure A2.1). Even though productivity growth reached its pre-crisis levels soon thereafter, from the end of 2011 it slowed down again, and Slovenia remained in recession for a prolonged period. The interesting question is, whether the crisis led to structural changes that undermine productivity growth in the future. If productivity growth has indeed shifted down permanently, this would have important consequences for long-term economic performance.

To test this, we use time series analysis and stability diagnosis techniques to detect potential structural breaks. Following the approach of Jimeno et al. (2006), the simultaneous estimation of breakpoints method developed by Bai and Perron (1998) is used. The method lets the data detect when breaks occur, but does not provide any structural explanations of why a break has occurred.

Structural breaks in productivity are explored using three series: quarterly growth rates of GDP per employed and GDP per hour, and total factor productivity contribution to growth. The GDP series and employment data is taken form Eurostat quarterly national accounts. Total hours worked are available on annual basis only and have been linearly interpolated. The TFP series is obtained from the growth accounting exercise performed using quarterly GDP (in volumes) series form the Eurostat quarterly national accounts, OECD quarterly series of productive capital stock and linearly interpolated OECD annual series of total hours worked. For more details see Dall'Orso and Sila (2015).

For each of the three series, four or five break dates are detected (Figure A2.1 and Table A2.1). For three of the identified breaks evidence is quite robust. In 2005Q1, Slovenia entered a period of accelerated productivity growth, which was then reduced strongly between 2007 and 2008. Towards the end of 2009/beginning of 2010 productivity growth returned to pre-2005 levels. On top of that, there is also evidence of one or two breaks in productivity growth in the early 2000s. More interestingly, the GDP per hour series offers tentative evidence that in 2011Q4 there was another structural break in productivity, bringing average productivity growth down again. 
Figure A2.1 Structural breaks

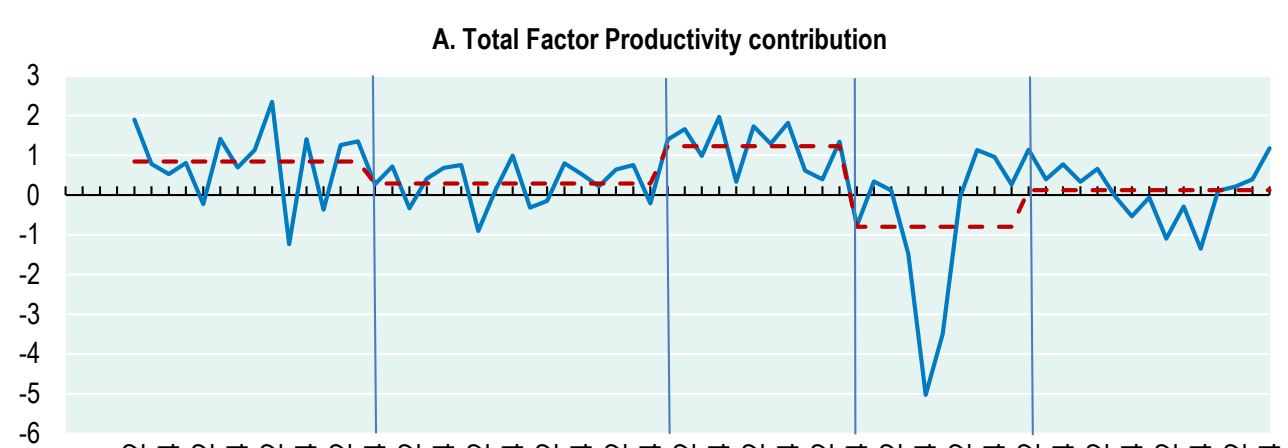

శี

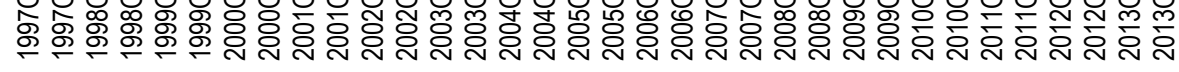

B. GDP ${ }^{1}$ per employed ${ }^{2}$ growth rate

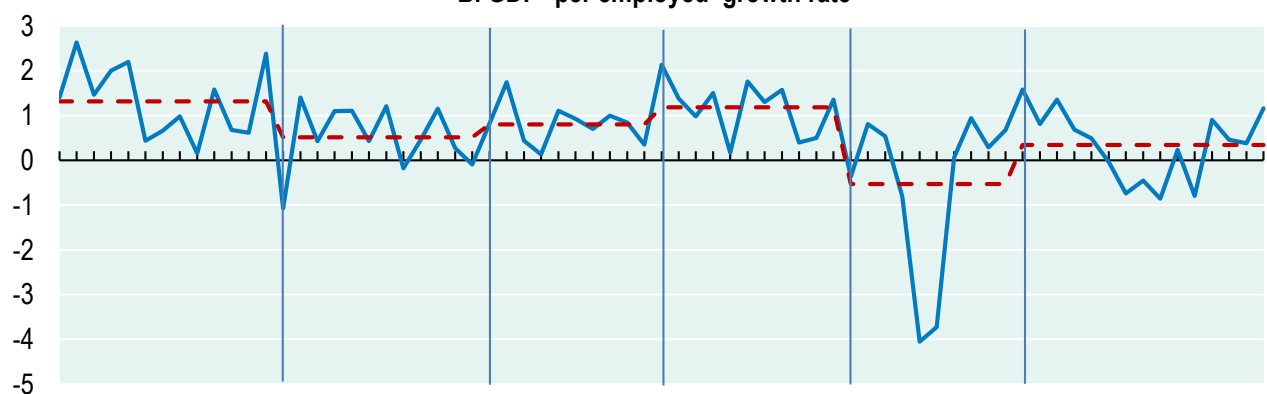

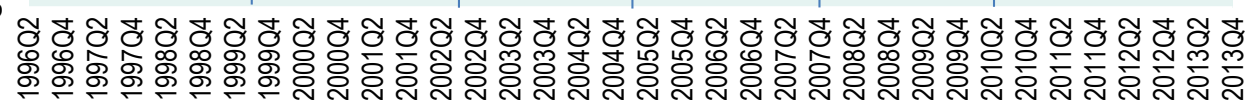

1. GDP at market prices measured in millions of euros, chain-linked volumes, reference year 2005 (at 2005 exchange rates).

2. Persons employed (total employment).

Source: Barro Lee educational attainment dataset, Eurostat and OECD National Accounts Statistics. OECD calculations.

Table A2.1 Structural break dates

Bai and Perron global simultaneous estimation

\begin{tabular}{lcccccc}
\hline $\begin{array}{c}\text { GDP/workers } \\
\text { growth rate } \\
\text { TFP contribution }\end{array}$ & $1999 \mathrm{Q} 3$ & $2002 \mathrm{Q}$ & $2005 \mathrm{Q} 1$ & $2007 \mathrm{Q} 4$ & $2010 \mathrm{Q} 2$ & \\
to growth \\
$\begin{array}{l}\text { GDP/hours growth } \\
\text { rate }\end{array}$ & $2000 \mathrm{Q} 4$ & $2005 \mathrm{Q} 1$ & $2007 \mathrm{Q} 4$ & $2010 \mathrm{Q} 2$ & \\
\hline
\end{tabular}

Source: OECD calculations.

Given the numerous breaks identified by this analysis, it is too early to conclude that the break identified in 2011Q4 and the lower average growth thereafter imply that productivity growth has come down more permanently. This is especially so, as in the most recent period productivity growth has recovered. Nevertheless, Slovenia should no doubt be cautious about its competitiveness and productivity growth and should implement policies to support them. 


\section{ANNEX 3 \\ THE IMPACT OF BUSINESS ENVIRONMENT ON PRODUCTIVITY AND ON FDI}

This Annex (see also Dall'Orso and Sila, 2015) focuses on the impact of institutional setting and foreign direct investment (FDI) on labour productivity, measured by GDP per person employed. An unbalanced panel of 34 OECD member countries is used, for the 1996-2013 period, from the OECD National Accounts Database. A fixed-effects model is estimated to control for unobserved heterogeneity across countries following Bijsterbosch and Kolasa (2009) and Box 3 in the 2012 Economic Survey of Finland.

First, the logarithm of productivity is regressed on R\&D intensity and expenditures on education (both measured as expenditures as a share of GDP), and capital intensity (measured as gross productive capital stock over employment). The capital intensity controls for variation in the industry mix and capital intensity. Table A3.1 column 1 shows that both the R\&D and the education expenditure have a positive impact on productivity levels, while the capital intensity does not seem to have a statistically significant impact on productivity.

Table A3.1 Determinants of productivity - panel of OECD member countries

\begin{tabular}{lccc}
\hline & $(1)$ & $(2)$ & $(3)$ \\
\cline { 2 - 4 } Dependent variable: log productivity & & & \\
\hline Capital intensity & $1.25 \mathrm{e}-09$ & $1.35 \mathrm{e}-09$ & $1.91 \mathrm{e}-09^{* *}$ \\
& $(1.23 \mathrm{e}-09)$ & $(8.25 \mathrm{e}-10)$ & $(8.79 \mathrm{e}-10)$ \\
R\&D intensity & $0.0758^{* * *}$ & -0.00941 & -0.00636 \\
& $(0.0173)$ & $(0.0170)$ & $(0.0164)$ \\
Expenditures on education & $0.0866^{* * *}$ & $0.0602^{* * *}$ & $0.0478^{* * *}$ \\
Barriers to entrepreneurship & $(0.0119)$ & $(0.00890)$ & $(0.00884)$ \\
& & $-0.0295^{* *}$ & $-0.0231^{* *}$ \\
Barriers to trade and invest & & $(0.0119)$ & $(0.0116)$ \\
& & $-0.0953^{* * *}$ & $-0.0912^{* * *}$ \\
State control & & $(0.00868)$ & $(0.00839)$ \\
& & $-0.0255^{* *}$ & $-0.0216^{* *}$ \\
FDI intensity & & $(0.0108)$ & $(0.0105)$ \\
& & & $0.000698^{* * *}$ \\
Observations & & & $(0.000215)$ \\
Number of countries & 432 & 365 & 362 \\
\hline
\end{tabular}

Note: Standard errors in parentheses $\left({ }^{\star * *} p<0.01,{ }^{* *} p<0.05,{ }^{*} p<0.1\right)$. All regressions are run using country fixed effects and include a constant term.

To determine the impact of the institutional setting on productivity levels, in column 2 we include the OECD PMR indicators on barriers to entrepreneurship, barriers to investment and trade, and the indicator of state control. Results show, as predicted, that all three barriers have a strong and statistically significant negative effect on productivity. For example, ceteris paribus, if Slovenia were to reduce its state control from 2.5 to 1.4 - the level of best performing country, the Netherlands - its productivity would be improved by $2.7 \%$. The impact of barriers to trade and investment is especially strong. A drop of this indicator to the average level (from 0.8 to 0.5 ) could lead to a productivity increase of $2.6 \%$. In column 3 , we additionally include the measure of FDI penetration - the inward stock of the FDI as \% of GDP. The coefficients of other institutional variables are not much changed. The results indicate that the FDI intensity (FDI as share of GDP) has a statistically significant positive effect on productivity. 
Next, the role of institutional factors on the FDI is explored. High barriers to entrepreneurship and barriers to trade and investment are expected to have a deterring effect on investment. Regressing FDI intensity on the institutional factors (Table A3.2, column 1), it is confirmed that all three institutional variables have a negative impact on the FDI intensity. The state control, which is high in Slovenia, has a strong negative impact on inward FDI. Column 2 suggests, that higher FDI brings more R\&D expenditure, and column 3 suggests that institutional factors are also important for the R\&D expenditure, partly also through their effect on the FDI (including the FDI intensity together with the institutional variables would render its coefficient statistically not significant).

Replicating the analysis also using Slovenian cross-sector data yields results consistent with the above. The database covers the time period 1995-2012 and includes 21 sectors from the NACE rev. 2 decomposition from the OECD STAN database, together with sector data on 1995-2012 annual inward FDI stocks from the Bank of Slovenia. We exclude the sector "Public administration and defence, compulsory social security" in order to better capture the impact on productivity in the "business sector".

Table A3.2 Influence of policy indicators on FDI intensity and R\&D intensity

\begin{tabular}{lccc}
\hline Dependent variable: & $(1)$ & $(2)$ & $(3)$ \\
\hline Barriers to entrepreneurship & FDI intensity & R\&D intensity & R\&D intensity \\
\hline Barriers to trade and investment & $-11.96^{* * *}$ & & $-0.171^{* * *}$ \\
& $(2.901)$ & & $(0.0442)$ \\
State control & $-5.744^{* *}$ & & $-0.0900^{* * *}$ \\
FDI intensity & $(2.501)$ & & $(0.0330)$ \\
& $-10.46^{* * *}$ & & $-0.134^{\star * *}$ \\
\hline Observations & $(2.618)$ & & $(0.0392)$ \\
Number of countries & & $0.00464^{* \star *}$ & \\
\hline
\end{tabular}

Note: Standard errors in parentheses $\left({ }^{* * *} p<0.01,{ }^{* *} p<0.05,{ }^{*} p<0.1\right)$. All regressions are run using country fixed effects and include a constant term.

Table A3.3 column 1 reports the results from regressing the logarithm of sector productivity, measured as GVA in volumes per person employed, on R\&D intensity (expenditure on R\&D in GVA) and capital intensity (the ratio of gross capital formation in volumes over total employment). The R\&D has a strongly positive impact on productivity, while capital intensity is not statistically significant. In column 2 , we include the sector FDI intensity, and it confirms the result that sectors with higher FDI have higher productivity. For a robustness check, and because of a special position of the financial sector in the recent crisis, in column 3 we do the same analysis, but excluding the financial sector. The positive effect of the FDI intensity becomes even stronger. 
ECO/WKP(2015)59

Table A3.3 The impact on Influence of R\&D intensity, capital intensity and FDI intensity on sector productivity

\begin{tabular}{lccc}
\hline & \multicolumn{2}{c}{ Including financial/insurance sector } & $\begin{array}{c}\text { Excluding } \\
\text { financial/insurance sector }\end{array}$ \\
\cline { 2 - 4 } & $(1)$ & $(2)$ & $(3)$ \\
\cline { 2 - 4 } Dependent variable: log productivity & $3.428^{* * *}$ & $2.489^{* *}$ & 1.304 \\
\hline R\&D intensity & $(1.238)$ & $(1.053)$ & $(0.986)$ \\
Capital intensity & 0.00183 & $0.00208^{*}$ & $0.00304^{* * *}$ \\
& $(0.00140)$ & $(0.00118)$ & $(0.00110)$ \\
FDI intensity & & $0.709^{* * *}$ & $1.904^{* * *}$ \\
& & $(0.0947)$ & $(0.212)$ \\
Observations & 152 & 152 & 137 \\
Number of sectors & 13 & 13 & 12 \\
\hline
\end{tabular}

Note: Standard errors in parentheses $\left({ }^{* \star *} p<0.01,{ }^{* *} p<0.05,{ }^{*} p<0.1\right)$. All regressions are run using sector fixed effects and include a constant term. 


\section{WORKING PAPERS}

The full series of Economics Department Working Papers can be consulted at www.oecd.org/eco/workingpapers

1240. Frontier firms, technology diffusion and public policy: micro evidence from OECD countries (June 2015) by Dan Andrews, Chiara Criscuolo and Peter N. Gal.

1239. Luxembourg - addressing new challenges in a major financial sector (June 2015) by Eckhard Wurzel and Damien Azzopardi

1238. Spillovers from the global productivity frontier and public policy: industry level evidence (June 2015) by Alessandro Saia, Dan Andrews and Silvia Albrizio

1237. The stabilisation properties of immovable property taxation: evidence from OECD countries (May 2015) by Hansjörg Blöchliger, Balázs Égert, Bastien Alvarez and Aleksandra Paciorek

1236. Making the most of natural resources in Indonesia

(May 2015) by Richard Dutu

1235. Reforming the pension system to increase coverage and equity in Colombia.

(May 2015) by Christine de la Maisonneuve

1234. Making Colombia's tax policy more efficient, fair and green

(May 2015) by Christian Daude, Sarah Perret and Bert Brys

1233. Skills and labour market performance in Sweden

(May 2015) by Margherita Bussi and Jon Kristian Pareliussen

1232. Skills and inclusive growth in Sweden

(May 2015) by Jon Kristian Pareliussen, Margherita Bussi, Christophe André and Vincent Koen

1231. Incorporating anchored inflation expectations in the Phillips Curve and in the derivation of OECD measures of equilibrium unemployment

(May 2015) by Elena Rusticelli, David Turner and Maria Chiara Cavalleri

1230. Macroeconomic uncertainties, prudent debt targets and fiscal rules,

(July 2015) by Falilou Fall and Jean-Marc Fournier

1229. Limits to government debt sustainability

(July 2015) by Jean-Marc Fournier and Falilou Fall

1228. Government debt indicators: understanding the data

(July 2015) by Debbie Bloch and Falilou Fall

1227. The costs of flexibility-enhancing structural reforms:a literature review

(July 2015) by Tito Boeri, Pierre Cahuc and André Zylberberg

1226. Household finance and income inequality in the euro area

(June 2015) by Oliver Denk and Alexandre Cazenave-Lacroutz 
1225. Financial sector pay and labour income inequality: evidence from Europe

(June 2015) by Oliver Denk

1224. Finance and income inequality in OECD countries

(June 2015) by Oliver Denk and Boris Cournède

1223. Finance and economic growth in OECD and G20 countries

(June 2015) by Boris Cournède and Oliver Denk

1222. What impedes household investment in energy efficiency and renewable energy?

(May 2015) by Nadia Ameli and Nicola Brandt

1221. Recent trends in productivity in China - shift-share analysis of labour productivity growth and the evolution of the productivity gap

(May 2015) by Margit Molnar and Thomas Chalaux

1220. Assessing China's skills gap and inequalities in education

(May 2015) by Margit Molnar, Boqing Wang and Ruidong Gao

1219. Providing the right skills to all in China - from "made in China" to "created in China"

(May 2015) by Margit Molnar and Vincent Koen

1218. Agricultural reforms and bridging the gap for rural China

(May 2015) by Ben Westmore

1217. A snapshot of China's service sector

(May 2015) by Margit Molnar and Wei Wang

1216. Does the post-crisis weakness of global trade solely reflect weak demand?

(May 2015) by Patrice Ollivaud and Cyrille Schwellnus

1215. Estonia: raising productivity and benefitting more from openness

(May 2015) by Andreas Kappeler

1214. Estonia: making the most of human capital

(May 2015) by Andrés Fuentes Hutfilter

1213. The Czech labour market: documenting structural change and remaining challenges

(May 2015) by Sónia Araújo and Petr Malecek

1212. Reforming the Slovak public sector

(April 2015) by Lilas Demmou and Robert Price

1211. Spurring growth in lagging regions in the Slovak Republic

(April 2015) by Lilas Demmou, Gabriel Machlica, Martin Haluš and Robert Menkyna

1210. Skill mismatch and public policy in OECD countries

(April 2015) by Müge Adalet McGowan and Dan Andrews 